\title{
AndHD
}

\section{Alman Hukukuyla Karşılaştırmalı Olarak Muhakemeye Katılan Süjelerin Tanık Olup Olamayacakları Sorunu(*)}

\author{
The Problem of Whether the Persons Participating \\ in Proceedings can be Witnesses in Comparison with German Law
}

Muhammed DEMIREL

Doktor Öğretim Üyesi

Ístanbul Üniversitesi Hukuk Fakültesi

Ceza ve Ceza Muhakemesi Hukuku Anabilim Dalı

\author{
Anahtar Kelimeler \\ Delil, \\ Tanıklı, \\ Tanık Beyanı, \\ Hâkim, \\ Müdafi, \\ Cumhuriyet Savclsl, \\ Bilirkişi, \\ Rollerin Çatışması.
}

Keywords

Evidence,

Testimony,

Witness Statement,

Judge,

Prosecutor,

Solicitor,

Expert,

Role Conflict.
Öz

Ceza muhakemesi hukukunun temel amacı, maddi gerçeğe ulaşmaktır ve bunun için muhakem€ konusu olaya ilişkin delil araştırılır. Ceza muhakemesinde hukuka uygun olarak elde edilen her şey delil olabilir. Bu deliller arasında olaya tanıklık eden kişilerin beyanı da yer almaktadır. Gelişen teknolojiyle birlikte yeni delil elde etme yöntemleri bulunmasına rağmen tanık beyanı, öne mini hiçbir zaman kaybetmemiştir. Hatta muhakeme konusu olaya ilişkin bilgi sahibi olan kişinin beyanda bulunması bir yükümlülük olarak görülmektedir. Tam bu noktada muhakemede görev alan hâkim, savcı, müdafi gibi kişiler, yargılama konusu olayla ilgili bilgi sahibi olurlarsa bu kişilerin tanık olup olamayacakları sorusu ortaya çıkmaktadır. Buna göre muhakeme konusu olayla ilgili tanıklık yapan bir savcı ya da müdafi, muhakeme konusu olayda görevine devam edecek midir? Bundan daha önemlisi; şüpheli ya da sanıklar, birbirleri aleyhine tanıklık yapabilirler mi? İşte bu incelemenin amacı, bu soruların cevaplarını Türk ve Alman hukukuyla karşılaştırmalı olarak vermektir.

\begin{abstract}
The main a m of criminal proceeding is to determine the material truth and so evidence related to the event, which is subject to justification, will be investigated. Everything lawfully obtained in criminal proceedings can be considered evidence. This evidence includes the testimony of those who witnessed the event. Although there are new methods of finding evidence with the evolving technology, testimony has never lost its relevance. It is even seen as an obligation for the person who is aware of the event to witness. At this point the question arises whether persons such as judges, prosecutors and solicitors who are taking part in the trial can be witnesses when they have information about the procedural event. Does that mean that a public prosecutor or defense attorney who testifies about the procedural facts will continue his service in the procedural case? More importantly, can suspects or accused witness against one another? The purpose of this review is to answer these questions in comparison to Turkish and German law.
\end{abstract}

(*) Araștırma Makalesi.

Hakem denetiminden geçmiştir.

Gönderim Tarihi : 01.01.2022, Makalenin Kabul Tarihi: 19.01.2022. 


\section{GENEL OLARAK}

Ceza muhakemesi hukukunda maddi gerçeğin tespit edilmesi amacına yönelik olarak ispat araçlarına başvurulur. Bu nedenle gerek soruşturma aşamasında savcı gerekse kovuşturma aşamasında hâkimin kendisi ya da mahkeme tarafından olayla ilgili tüm deliller araştırılır. Cumhuriyet savcısı, iddianame düzenleyip düzenlemeyeceği konusunda mevcut delillerin fiilin işlendiği konusunda yeterli şüphe ortaya koyup koymadığını esas alır. Yine hâkim veya mahkeme, mevcut delillerle yetinmeyip kovuşturma aşamasında delil araştırmasına devam edebilir ve delillerin doğrudanlığı ilkesi gereğince bütün delilleri duruşmada tartıştırır, böylelikle isnat edilen suçun ispatına yönelik bir kanaate ulaşmaya çalışır. Hâkim veya mahkeme, isnat edilen fiilin sanık tarafindan işlendiği hususunda bir şüpheye düşerse şüpheden sanık yararlanır prensibi (in dubio pro reo) gereğince sanık hakkında beraat kararı verir. Bu bakımdan hâkim veya mahkemenin, yargılama konusu fiilin sanık tarafindan işlendiği konusunda tam anlamıyla vicdanî bir kanaate ulaşması gerekir. İşte tam bu noktada araştırılıp tespit edilen deliller etkili olmaktadır ki burada da delillerin elde edilmesi bağlamında çeşitli ispat araçları gündeme gelmektedir. Bu ispat araçlarından biri detanıklıktır ${ }^{1}$ ve burada delil olan tanık konumundaki kişinin beyanıdır.

Teknolojik ilerlemeler, ispat araçlarında birtakım gelişmeleri beraberinde getirmişse de geleneksel ispat aracı olan tanıklık ve beyan delili olarak nitelendirilen tanık beyanı, hiçbir şekilde önemini kaybetmemiş, yerini ve değerini her daim korumayı sürdürmüştür ${ }^{2}$. Bunun en temel sebebi, tanıklığın sınırlı sayıdaki ${ }^{3}$ (numerus clausus) diğer maddi ispat araçlarıyla değiştirilemez ve yerinin doldurulamaz nitelikte olmasi ${ }^{4}$ ve tanık beyanının yaşanan olay hakkında doğrudan bilgi veren deliller arasında yer almasıdır ${ }^{5}$. Bu nedenle öğretide tanıklığın en yaygın kullanılan ispat araçlarından biri olduğuna ${ }^{6}$ ve ceza muhakemesi uygulamasında oldukça önemli bir yere sahip bulunduğuna dikkat çekilmektedir? Yalnızca kişilerin beyanlarına dayalı olması nedeniyle şahsa bağlı ispat aracı olarak nitelendirilen tanıklık, Ceza Muhakemesi Kanunu'nun (CMK) “Tanıklık, Bilirkişi İncelemesi ve Keşif” başlıklı üçüncü kısım altında, Alman Ceza Muhakemesi Kanunu'nun (AlmCMK) ise bilirkişi ve keşiften evve 6'ncı kısmında düzenlenmiştir. Bu çerçevede ispat hukuku enstrümanı olan ve her iki hukuk

KUDLICH, Hans/ROY, René “DieZeugnisverweigenungsrechte der StPO”, Juristische Arbeitsblätter (JA), 2003, s. 565.

KOCA, Mahmut: “Ceza Muhakemesi Hukukunda Deliller”, Ceza Hukuku Dergisi, 2006, Sayı 1, s. 215, 216.

3 KINDHÄUSER, Urs / SCHUMANN, Kay H.: Strafprozessrecht, 5. Auflage, Nomos, Baden-Baden, 2019, § 21, kn. 1; KREY, Volker / HEINRICH, Manfred: Deutsches Strafverfahrensrecht, 2. Auflage, Verlag W. Kohlhammer, Stuttgart, 2019, kn. 1210; VOLK, Klaus / ENGLÄNDER, Armin: Grundkurs StPO, 10. Auflage, C.H.Beck, München, 2021, § 20, kn. 1; HARTMANN, Arthur / SCHMITT, Rolf: Strafprozessrecht, 7. Auflage, Rolf Schmidt Verlag, Hamburg, 2018, kn. 245a; BADER, Markus: Karlsruher Kommentar zur Strafprozessordnung mit GVG, EGGVG und EMRK, 8. Auflage, C.H.Beck, München, 2019, vor § 48, kn. 1; BEULKE, Werner / SWOBODA, Sabine: Strafprozessrecht, 15. Auflage, C.F.Müller, Heddelberg, 2020, kn. 284; OSTENDORF, Heribert / BRUNING, Januque: Strafprozessrecht, 4. Auflage, Nomos, Baden-Baden, 2021, § 16, kn. 2.

4 BGH NJW 1984, 247 (PFEIFFER, Gerd: Strafprozessordnung Kommentar, 5. Auflage, Verlag C.H.Beck, München, 2005, vor § 48, kn. 1); HEGHMANNS, Michad: Strafverfahren, Springer, Heidelberg, 2014, kn. 420; ALSBERG, Max / DALLMEYER, Jens: Der Beweisantrag im Strafprozess, 7. Auflage, Carl Heymanns Verlag, Köln, 2019, kn. 305.

5 KOCA, s. 215; GÖKTÜRK, Neslihan: "Yalan Tanıklık Suçu (TCK m. 272)", Gazi Üniversitesi Hukuk Fakültesi Dergisi, 2016, Cilt 20, Sayı 1, s. 349; İNCE TUNÇER, Asuman: Yalan Tanıklık Suçu, Seçkin Yayıncılık, Ankara, 2020, s. 21.

6 IGNOR, Alexander / BERTHEAU, Camilla: Löwe-Rosenberg Die Strafprozeßordnung und das Gerichtsverfassungsgesetz, Band 2, 27. Auflage, De Gruyter, Berlin, 2018, vor § 48, kn. 13; von SCHLIEFFEN, J asper Graf: in AnwaltKommentar StPO Strafprozessordnung, 2. Auflage, Deutscher Anwalt Verlag, Bochum, 2010, vor $\S 48$, kn. 1; PFEIFFER, vor $\S 48$, kn. 1; HEGHMANNS, kn. 371; GÖKTÜRK, S. 349. Feyzioğlu, tanıklığın bir delil aracı değil, delilin kaynağı olduğunu, muhakeme esnasında doğrudan doğruya incelenenin tanığın kendisi değil, beyanının olduğunu, tanığın beyanının ancak yetkili makamın bu beyanın inandıııcılı̆ı konusunda kanaate varması halinde delil olacağını ifade etmiştir (FEYZİĞLU, Metin: Ceza Muhakemesi Hukukunda Tanıklık, US-A Yayıncılık, Ankara, 1996, s. 26).

7 GERCKE, Björn: Strafprozessordnung, Heidelberger Kommentar, 6. Auflage, C.F.Müller, Heidelberg, 2019, vor § 48, kn. 1; BADER, vor $\S 48, \mathrm{kn}$. 1; MIEBACH, Klaus: "Die freie Beweiswürdigung der Zeugenaussage in der neueren Rechtsprechung des BGH", Neue Zeitschrift für Strafrecht-Report (NStZ-RR), 2014, S. 233. Hatta von Schlieffen, tanıklı̆̆1 ispat hukukunun y1ldızı olarak nitelendirmenin haksız olmayacağını ifade etmiştir (von SCHLIEFFEN, vor $§ 48, \mathrm{kn}$. 1). Pfeiffer iseAlman ceza muhakemesi hukukunda tanıklığın ideal tipte bir ispat șekli olduğuna dikkat çekmiștir (PFEIFFER, vor § 48, kn. 1). Türk öğretisinde de tanıklığın önemli olduğuna vurgu yapılmıştır. Bkz. YURTCAN, Erdener: Ceza Muhakemesi Kanunu Şerhi, 9. Baskı, Seçkin Yayıncılık, Ankara, 2019, s. 213; YENISEY, Feridun / NUHOĞLU, Ayşe: Ceza Muhakemesi Hukuku, 8. Baskı, Seçkin Yayıncılık, Ankara, 2020, s. 518; TOROSLU, Nevzat / FEYZIOĞLU, Metin: Ceza Muhakemesi Hukuku, 20. Baskı, Savas Yayınevi, Ankara, 2020, s. 208; ÜNVER, Yener / HAKERİ, Hakan: Ceza Muhakemesi Hukuku, 16. Bask1, Adalet Yayınevi, Ankara, 2019, s. 254; ÖZBEK, Veli Özer / DOĞAN, Koray / BACAKSIZ, Pınar: Ceza Muhakemesi Hukuku, 14. Baskı, Seçkin Yayıncılık, Ankara, 2021, s. 585; GÖKTÜRK, s. 349; İNCE TUNÇER, s. 23.

8 Strafprozeßordnung (StPO). 
sisteminde de ispat araçları altında konumlan tanıklık, olay ya da olguyu idrak eden kişinin yerine bir başka kişinin tanıklık yapmasından söz edilemeyeceğinden ${ }^{9}$ şahsa bağlı ispat aracı olarak görülmekte dir ${ }^{10}$. Keza bir kişinin olgulara ilişkin algılamaları ve bunları ifade ediş şekli kendisine özgü olduğundan tanıklık tamamen şahsi bir nitelik arz eder ve çoğu zaman ne bu kişi başka bir kişiyle ne de başlı başına tanıklık şeklindeki ispat aracı başka bir ispat aracıyla ikame edilebilir ${ }^{11}$.

Bu açıklamalardan hareketle Türk hukuku ve Alman hukukunda tanıklığa ilişkin kanunî düzenlemelerin ve uygulamanın, bazı farklılıklar dışında büyük oranda benzeştiği ifade edilebilir. Bu nedenle bu konuda Türk ve Alman hukuku üzerinden bir karşılaştırma yapılarak inceleme yapılmasının mümkün ve hatta oldukça faydalı olacağı kanaatindeyiz. Nitekim her iki hukuk sisteminde de tanıklık, bir ispat aracıdır ve tanıkların davete icabet edip huzurda bulunma, gerçeğe uygun ifade verme ve nihayet istisnaî durumlar haricinde yemin etme yükümlülükleri bulunmaktadır. Buna göre yurt içinde bulunan yabancılar da dâhil olmak üzere tanıklıktan çekinme hakkına sahip olsa bile ilgili ülke yargılama sistemine tabi olan herkes, kurallara uygun çağrı üzerine kural olarak hâkim huzuruna (CMK m 43, 44; Alm.CMK $\S ~ 48$ I, 51) ve soruşturma aşamasında savcının huzuruna gelmek zorundadır (§ 161a I 1). Her iki hukuk sisteminde de tanıkların hâkim ya da mahkeme huzurunda yahut da savcı tarafindan dinlenmesi mümkündür (CMK m 43/5; AlmCMK § 16la I 1, II). Bunun yanı sira Türk hukukundan farklı olarak Alman hukukunda 17.08.2017 tarihinde yürürlüğe giren reform kanunuyla birlikte; soruşturma aşamasında, savcı tarafından özel bir emir söz konusu olmak şartıyla soruşturmayla görevli kişilerin (soruşturmada görevli polis memurları) daveti üzerine tanığa beyanında bulunma yükümlülüğü getirilmiştir (AlmCMK § 163 III 1) ki bu bağlamda tanık, Alman hukuk uygulamasında gerektiğinde polis önünde de hazır bulunmalıdır ${ }^{12}$. Bu çerçevede Alman hukukunda tanık, sadece mahkeme, savcı ve savcının soruşturma kişisi olması ve "savcının emrini esas alması" şartıyla polis önünde ifa denin konusu üzerinde konuşmakla yükümlü kılınmıştır (AImCMK §§ 48I 2; §§ 161al 1, II, 163 III). Türk hukukunda ise kolluk görevlisinin olay mahallinde bulunanların bilgisine başvurması, Polis Va zife ve Salahiyet Kanunu' nun 15' inci maddesinde yer alan "polis, yaptı̆̆g tahkikat esnasinda ifadelerine müracaat lazım gelen kimseleri çağırır ve kendilerine lüzum olan şeyleri sorar" hükmü gereğince tanık beyanının alınması değil, yalnızca bir bilgi alma işlemidir ve dolayısıyla bu kişilerin beyanları, "tanık beyanı" olarak kabul edilmez ${ }^{13}$, ancak yazılı olduğu için belge delili olarak nitelendirilebilir ${ }^{14}$.

Kuşkusuz ki tanıkların dinlenmesi konusunda hangi mercilerin yetkili olduğu, yargılama konusu olayda bu kişilerin tanıklık yapıp yapamayacaklarının tespiti noktasında önem arz etmektedir. Bu çer-

9 RGSt 52, 289 (JOECKS, Wolfgang: Strafprozessordnung Studienkommentar, 4. Auflage, C.H.Beck, München, 2015, vor § 48, kn. 1).

BGH NJ W 1984, 249 (GERCKE, vor § 48, kn. 2); MAIER, Stefan / PERCIC, Marcus: Münchener Kommentar Strafprozessordnung, 1. Auflage, C.H.Beck, München, 2014, vor $\S$ 48, kn. 1; ROGALL, Klaus: Systematischer Kommentar zur Strafprozessordnung mit GVG und EMRK, Band I, 5. Auflage, Carl Heymanns Verlag, Köln, 2018, vor § 48, kn. 7; OTTE, Lars: in Henning Radtke/Olaf Hohmann Strafprozessordnung Kommentar (HH), Verlag Franz Vahlen, München, 2011, § 48, kn. 1; PFEIFFER, vor § 48, kn. 1; GEPPERT, Klaus: "Der Zeugenbeweis", Juristische Ausbildung (Jura), 2001, s. 80-88; OSTENDORF / BRUNING, § 16, kn. 4; ALSBERG / DALLMEYER, kn. 303; KUDLICH / ROY, s. 565; MICHEL, Norbert: "Der Richter als Zeuge im Strafverfahren”, Monatsschrift für Deutsches Recht (MDR), 1992, s. 1026.

11 RGSt 47, 104 (JOECKS, vor § 48, kn. 1).

12 BEULKE / SWOBODA, kn. 292; VOLK / ENGLÄNDER, § 20, kn. 5; HARTMANN / SCHMITT, kn. 251. Burada ifadeyi yöneten kişinin, savcılık nezdinde soruşturmada görevli kişilerden olması yeterlidir. Bu hüküm kapsamındaki koşullar (savcının soruşturma kişisi ve savcının özel emrine uygun davet) gerçekleşmezse polis memurunun tanıklık yapmaya yönelik daveti, herhangi bir sorumluluk ge rektirmeyen ve tanı̆̆ın buna önceki gibi uymak zorunda olmadığı bir davet olur (VOLK / ENGLÄNDER, § 20, kn. 5; BEULKE / SWOBODA, kn. 292). Şayet tanık yetkili olmayan polisin davetine rağmen ya da kendiliğinden gelirse her polis memuru ifadeyi almaya yetkilidir. Tanığın savcının soruşturma kişisi olarak polis memurunun özelliği üzerinde ya da savcının mevcut daveti üzerinde hataya düşmesi halinde ispat değerlendirme yasağının olup olmayacağı tam olarak açıklığa kavuşturulmuş değildir (BEULKE / SWOBODA, kn. 292). Kuşkusuz ki mahkemenin tanığı yemin suretiyle dinleme hakkı (Alm.CMK § 163 III 3) saklı kalır (HARTMANN / SCHMITT, kn. 251).

13 FEYZİOĞLU, s. 30, 31; GÖKCEN, Ahmet / BALCI, Murat / ALŞAHIN, M. Emin / ÇAKIR, Kerim: Ceza Muhakemesi Hukuku, 5. Bask1, Adalet Yayınevi, Ankara, 2020, s. 287; GÖKTÜRK, s. 364.

14 KUNTER, Nurullah: Ceza Muhakemesi Hukuku, Beta Yayıncılık, İstanbul, 1989, s. 632; TOROSLU / FEYZİOĞLU, s. 207. Türk öğretisinde Aydın tarafindan soruşturma evresinde Cumhuriyet savcısı ya da sulh ceza hâkimi önünde tanık kişi tarafindan yapılan açıklamaların tanık beyanı olamayacağı, bu açıklamaları içeren tutanakların belge delili niteliğinde olduğu iddia edilmiștir (AYDIN, DeVrim: Ceza Muhakemesinde Deliller, Yetkin Yayınları, Ankara, 2014, s. 67). Bu görüş, CMUK dönemine dayanmaktadır. Bkz. KUNTER, s. 632. 
çevede incelememizde her iki hukuk sisteminde konularla bağlantılı olarak karşılaştırmalı şekilde hukuki düzenlemelere yer verilecek, şayet benzerlik gösteriyorlarsa bu hukuki normlara bağlı olarak şekillenen görüşler ortak şekilde belirtilecek, bununla birlikte ilgili hukuk sistemine özgü bir uygula ma ya da öğretide görüş mevcutsa bu durum özel olarak vurgulanacaktır. İncelememizde evvela tanıkl1k kavramına ve tanıklığın konusuna yer verilecek, sonrasında da muhakeme sürecindeki hâkim, savc1, müdafi, şüpheli ve sanık ile nihayet mağdur, bilirkişi, zabit kâtibi ve kolluk görevlilerinin tanık olup olamama durumları ayrıntılı şekilde irdelenecektir.

\section{TANIKLIK KAVRAMI VE TANIKLIĞIN KONUSU}

\section{A. Kavram}

Türk Ceza Muhakemesi Kanunu ve Alman Ceza Muhakemesi Kanunu'nda tanıklığın tanımına yer verilmemiş, fakat her iki kanun kapsamında bu ispat aracı üzerine genel hükümler düzenlenmiştir (CMK m 43 vd.; AlmCMK §§ 48). Alman öğretisinde tanık, Alman Krallık Yüksek Mahkemesinin tanığın ifade yükümlülügünü ortaya koyduğu kararlarda yer alan ifadeler üzerinden tanımlanmakta$\mathrm{d}_{1} \mathrm{r}^{15}$. Buna göre tanık, kendisine karşı yürütülmeyen bir yargılamada olay ya da olgular üzerine beş duyu ile edindiği algılamalarını ortaya koyabilecek olan gerçek kişidiri ${ }^{16}$. Kişi, olay ya da olguları bizzat görmüş olabileceği gibi bir patlama sesini duymuş ya da gaz kokusunu koklaması nedeniyle hissetmiş de olabilir. Tanıklık için bunlardan herhangi biri yeterli olacaktır ${ }^{17}$. Bu tanımda yer alan "kişinin kendisine karşı yürütülmeyen yargılama olması" yönündeki ifade, esasen bir çekince olarak görülmektedir. Buna göre tanığın muhakemede şüpheli ya da sanık yahut mağdur şeklinde herhangi bir tarafta bulunmaksızın savcı yahut hâkim ya da mahkeme önünde ol ay ve olgular üzerine sözlü olarak beyanda bulunmas1 önem arz etmektedir ${ }^{18}$. Bununla birlikte Rogall, tanığın yargilamaya katılmas1 zorunlu olan, bu konuda hukuken yükümlü olan kişi olduğuna da dikkat çekmiş ve maddi unsuru içeren klasik tanıma "beyanda bulunmaya yönelik olarak hukuken yükümlü olan kişi" yönündeki şekli unsurun da dâhil edilmesi gerektiğini belirtmiştir ${ }^{19}$. Şu hâlde tanık, (i) kural olarak kendisinin herhangi bir şekilde şüpheli veya sanık ya da măgdur olarak yer almadı̆̆ bir yargılamada, (ii) dişsal olay ya da olgular veya içsel olgular üzerine beş duyu organından en az biriyle idrak ettiği algılamalarını, (iii) pozitif veya negatif yöndeki ifadeleriyle ortaya koyabilecek olan, (iv) yetkili makam tarafindan davet edildiğinde huzurda bulunup kanuni bir neden olmaksızın beyanda bulunma konusunda, $(v)$ hukuken yükümlü olan kişidir ${ }^{20}$.

15 IGNOR / BERTHEAU, vor $\S 48$, kn. 8.

16 RG v. 12.08.1918 - IV 696/18, RGSt 52, 289 (OTTE, § 48, kn. 1); SCHMITT, Bertram in Beckische Kurz Kommentar, MeyerGoßner/Schmitt Strafprozessordnung mit GVG und Nebengesetzen, 64. Auflage, C.H.Beck, München, 2021, vor § 48, kn. 1; BEULKE / SWOBODA, kn. 286; ROXIN, Claus / SCHUNEMANN, Bernd: Strafverfahrensrecht, 29. Auflage, C.H.Beck, München, 2017, § 26, kn. 1; KINDHÄUSER / SCHUMANN, § 21, kn. 6; BADER, vor § 48, kn. 1; KÜHNE, Hans-Heiner: Strafprozessrecht, 9. Auflage, C.F.Müller, Heidelberg, 2015, kn. 795); RGSt 47, 104 (IGNOR / BERTHEAU, vor § 48, kn. 8); BGHSt 22, 347 (HARTMANN / SCHMITT, kn. 245); KREY / HEINRICH, kn. 1210; MAIER / PERCIC, vor § 48, kn. 1; EISENBERG, Ulrich: Beweis der StPO, Spezialkommentar, 10. Auflage, C.H.Beck, Müchen, 2017, kn. 1000; von SCHLIEFFEN, vor § 48, kn. 1; OSTENDORF / BRUNING, § 16, kn. 4; HEGER, Martin / POHLREICH, Erol: Strafprozessrecht, 2. Auflage, Verlag W. Kohl hammer, Stuttgart, 2018, kn. 366a; ALSBERG / DALLMEYER, kn. 303; KUDLICH / ROY, s. 565; MICHEL, s. 1026; KUNTER, s. 631; CENTEL, Nur / ZAFER, Hamide: Ceza Muhakemesi Hukuku, 19. Bask1, Beta Yayıncılık, İstanbul, 2020, s. 283; TOROSLU / FEYZIOĞLU, s. 207; ŞAHIN, Cumhur / GÖKTÜRK, Neslihan: Ceza Muhakemesi Hukuku, Cilt II, 11. Bask1, Seçkin Yayıncılık, Ankara, 2021, s. 39; GÖKTÜRK, s. 373; FEY ZIOĞLU, s. 28; ÜNVER / HAKERİ, s. 254; GÖKCEN / BALCI / ALŞAHIN / ÇAKIR, s. 285; ÖZBEK / DOĞAN / BACAKSIZ, s. 585; KARAKEHYA, Hakan: Ceza Muhakemesi Hukuku, 2. Baskı, Savaş Yayınevi, Ankara, 2016, s. 222; AYDIN, s. 66. KUNTER, s. 633; KARAKEHYA, s. 223.

18 ROGALL, vor $§ 48$, kn. 11; YENISEY / NUHOĞLU, s. 536; AYDIN, s. 66; İNCE TUNÇER, s. 21. Bu noktada Feyzioğlu'na göre uyușmazlığın șahıs itibariyle taraf olmaması șartı değil, makam itibariyle taraf olmama șartının dikkate alınması daha makuldür (FEY ZİOĞLU, s. 40)

19 ROGALL, vor § 48, kn. 11. Türk öğretisinde bu yönde tanım için bkz. FEYZİOĞLU, s. 28, 29; ÜNVER / HAKERİ, s. 254.

20 Nitekim Yargıtay Ceza Genel Kurulu'nun 2019/460 Esas, 2019/572 Karar sayılı ve 01.10.2019 tarihli kararında şu ifadelere yer verilmiştir: "Tanıklı, kamu hukukundan doğan toplumsal bir ödevdir. Bu nedenle tanığın, hukuka uygun olarak yapılan davet üzerine adli makamlar önüne gelmek, bildiklerini doğru olarak anlatmak ve yemin etme ödevi bulunmaktadır. Bununla birlikte ceza muhakemesinde tanığa bazı haklar da tanınmıştır. Tanığın, tanıklıktan çekinme, kendisi ve yakınları aleyhine açıklamada bulunmaktan çekinme, haklarını öğrenme, korunma, tazminat ve masrafların isteme hakkı vardır.” Karar için bkz. İNCE TUNÇER, s. 24, dn. 32. 
Kişinin hangi nedenden dolayı tanıklık yapma yükümlülügünün ortaya çıtı̆̆ı, söz konusu olgulara dair bilgisinin görevlendirme mi, meslek gereği mi, tesadüfi mi, doğrudan mı yoksa dolaylı mı olduğunun bir önemi bulunmamaktadır ${ }^{21}$. Bu bakımdan bir hemşirenin tanıklık ifadesinde; yaralı mağdurun yaralanmasına sebep olan failin aslında eşi olduğu yönünde kendisine sır verdiğini be lirtmesinde olduğu gibi "bizzat idrak edilen değil, idrak eden kişiden duyulan hususların bildirilmesi suretiyle" de tanıklık mümkündür ki buna "ikinci derece tanıklık"22, "kulaktan duyma tanıklık"23", "dolaylı tanıklık ${ }^{24 "}$ ya da "tanığın tanığı ${ }^{25 "}$ adı verilmektedir. Dolaylı tanık, doğrudan idrak ettiği hususları değil, üçüncü kişiden öğrendiği hususları bildiren kişidir ${ }^{26}$. Hatta bazen bilginin ilk elden kimden edinildiği de belirsiz olabilir ki bu durumda dahi bu tanık beyanı en baştan değersiz olarak görül $\mathrm{mez}^{27}$. Bu tanıklık türü, uygulamada özellikle gizli soruşturmacının (CMK m 139), gizli soruşturma yürüten kolluk görevlilerinin ifade vermeleri bağlamında önem arz etmektedir ${ }^{28}$. Tanığın duyduklarını ifade etmesi, nihayetinde doğrudan kendi idrak ettiği hususları bildirmesi nedeniyle ispat araçlarının doğrudanlığı ilkesini ihlâl etmez ${ }^{29}$. Elbette mahkeme, her durumda doğrudan olguları bizzat idrak eden kişiye ulaşmaya çalışmış olmalıdır ${ }^{30}$. Ancak Alman öğretisinde bir görüş ${ }^{31}$, bu olguları doğrudan idrak eden tanığa ulaşıp onu dinlemek mümkün olsa bile bu kişiden duyduklarını beyan eden kişinin tanıklık ifadeleriyle de yetinilebileceğini, bunun delillerin doğrudanlığ ilkesini ihlâl etmeyeceğini belirtmektedir. Gerçek şu ki, Türk öğretisinde ${ }^{32}$ de kabul edildiği üzere mahkeme her durumda olabildiğince en iyi olan yöntemi seçmeli, orijinal ispat aracına ulaşmaya yönelik ola rak bir çaba göstermiş olmalıdır ${ }^{33}$. Bu noktada duyduklarını beyan eden tanığın ifadelerinin dikkatli bir şekilde değerlendirilmesi şart olup ${ }^{34}$ olguları ilk idrak edenle bu kişiden bunları duyan kişi arasında ne kadar fazla kişi varsa ifadenin ispat değerinin o kadar düşük olduğu hususu göz ardı edilmemelidir ${ }^{35}$. Bazen dolaylı tanıklık, doğrudan tanıklık kadar değerli olabilir. Nitekim olay yerine

21 BVerfGE 57, 292 (ROGALL, vor § 48, kn. 25); BGH v. 16.04.1985 - 5 StR 718/84, BGHSt 33, 178 (OTTE, § 48, kn. 1); BGH NJW 1985, 1789 (GERCKE, vor § 48, kn. 2); SCHMITT, vor § 48, kn. 1; PFEIFFER, vor § 48, kn. 4; ALSBERG / DALLMEYER, kn. 305; MICHEL, 1026; ÖZTÜRK, Bahri / TEZCAN, Durmus / ERDEM, Mustafa Ruhan / GEZER, Özge Sirma / SAYGILAR KIRIT, Yase min F. / ALAN AKCAN, Esra / TÜTÜNCÜ, Efser Erden / ÖZAYDIN, Özlem / ALTINOK VILLEMIN, Derya / TOK, Mehmet Can: Nazari ve Uygulamalı Ceza Muhakemesi Hukuku, 15. Bask1, Seçkin Yayıncılık, Ankara, 2021, s. 301; ÜNVER / HAKERİ, s. 254; ŞAHIN / GÖKTÜRK, s. 40; GÖKCEN / BALCI / ALŞAHIN / ÇAKIR, s. 285; INNCE TUNÇER, s. 25.

22 SAHIN / GÖKTÜRK, s. 40. Bu ifade, haklı olarak Feyzioğlu tarafindan yerinde görülmemektedir. Zira yazara göre bu șekilde isimlendime, değerlendirmede sanki yetkili makamın serbestisini sınırlandıracak bir durum varmış izlenimi oluşturabilecektir (FEYZIOĞLU, s. 68).

23 BGH 16.04.1985 - 5 StR 718/84, BGHSt 33, 178 (MAIER / PERCIC, vor § 48, kn. 1); HARTMANN / SCHMITT, kn. 247; VOLK / ENGLÄNDER, § 20, kn. 4; KREY / HEINRICH, kn. 1213; IGNOR / BERTHEAU, vor § 48, kn. 8; BADER, vor § 48, kn. 1; ROGALL, vor § 48, kn. 25; BEULKE / SWOBODA, kn. 286; PFEIFFER, vor § 48, kn. 4; OSTENDORF / BRUNING, § 16, kn. 4. Bu konu hakkında detaylı bilgi ve izahat için bkz. SEEBODE, Manfred / SYDOW, Fritz: “'Hörensagen ist hall b gelogen' Das Zeugnis vom Hörensagen im Strafprozeß", Juristenzeitung (JZ), 1980, s. 506-516.

24 MIEBACH, s. 233; CENTEL / ZAFER, s. 283; SAHIN / GÖKTÜRK, s. 39, 40; ÖZEN, s. 321.

25 CENTEL / ZAFER, s. 283

26 GERCKE, vor § 48, kn. 20; EISENBERG, kn. 1027; OSTENDORF/BRUNING, § 16, kn. 4 HEGER / POHLREICH, kn. 366a; KUNTER, s. 634; FEYZIOĞLU, s. 65; ÖZTÜRK / TEZCAN / ERDEM / GEZER / SAYGILAR KIRIT / ALAN AKCAN / TÜTÜNCÜ / ÖZAYDIN / ALTINOK VILLEMIN / TOK, 301; ŞAHIN / GÖKTÜRK, 39, 40; GÖKCEN / BALCI / ALŞAHIN / ÇAKIR, s. 285; KARAKEHYA, s. 223; ÖZEN, s. 321; AYDIN, s. 68; INCE TUNÇER, s. 26.

27 FEYZİĞLU, s. 68.

28 GERCKE, vor $\S 48$, kn. 20; PFEIFFER, vor $\$ 48$, kn. 4; SEEBODE / SYDOW, s. 506; FEYZİĞLU, s. 69; SAHIN / GÖKTÜRK, s. 41; ÖZTÜRK / TEZCAN / ERDEM / GEZER / SAYGILAR KIRIT / ALAN AKCAN / TÜTÜNCÜ / ÖZAYDIN / ALTINOK VILLEMİN / TOK, s. 211; GÖKCEN / BALCI / ALŞAHİN / ÇAKIR, s. 285; İNCE TUNÇER, s. 25; TAŞKIN, Ozan Ercan: Kışkırtıcı Ajan, Seçkin Yayıncılık, Ankara, 2011, s. 223-227.

29 RGSt 48, 246 (ROGALL, vor § 48, kn. 25); BGH StV 1988, 91 (GERCKE, vor § 48, kn. 20).

30 BGH NStZ 2004, 50 (GERCKE, vor § 48, kn. 20).

31 SCHMITT, § 250, kn. 4.

32 ŞAHİN / GÖKTÜRK, s. 40.

33 GERCKE, vor § 48, kn. 20; EISENBERG, kn. 1031.

34 MIEBACH, s. 236. Bu noktada bu tür delillerin başka delillerle de desteklenmesi gerektiğine işaret edilmiş, böyle bir durumda Avrupa İnsan Hakları Mahkemesi tarafindan Sözleşme’ye aykırılık bulunmadığı sonucuna ulaşıldığı vurgulanmıştır. Bkz. AYDIN, s. 69.

35 BGHSt 17, 385 (GERCKE, vor § 48, kn. 20). Keza bu konuda Aydın, duyuma dayalı tanığın bildiklerinin kendisine aktarılanla sinırlı olduğundan olayı temsil etme gücünün daha zayıf olduğunu, buna rağmen bu durumun duyuma dayalı tanıklı̆ğn reddedilmesini gerektirmediğini ifade etmiştir (AYDIN, s. 69). 
sonradan gelen bir kişinin olay yerinde olanları oradaki kişilerden dinleyip tanıklık yapması halinde beyanı, olayı bizzat gören kişininki kadar değerli görülebilir ${ }^{36}$.

Tanıklığa ilişkin tanımda yer alan "olay ve olgular üzerine algı" ifadesi, tanıklığın zayıf yönünü ortaya koymaktadır ve bu açıdan tanıklık, örneğin keşif karşısında daha sübjektif bir nitelik arz etmektedir ${ }^{37}$. Zira tanık, bazen olayın yaşandığı an ile tanıklık yapılan an arasında uzun bir zamanın geçmiş olması, bazen algıladığı hususların doğruluğuna inanarak yanılma gibi nedenlerle objektif olarak yanlış beyanda bulunabileceği gibi kasıtlı olarak hatalı beyan da verebilir, diğer bir deyişle yalan tanıklık yapabilir ${ }^{38}$. Bu noktada kişinin beyanlarının tanıklık olarak nitelendirilmesi için olgunun gerçekten meydana gelip gelmediği ya da bunların ifadeye hakiki anlamda yansıyıp yansımadığı önemsizdir ${ }^{39}$. Bu bakımdan tanığın bilinçli şekilde yalan söylemesinden ziyade çoğu zaman tanıktaki algının seçici olması ve kişilik olarak çeşitli etkilere açık olabilmesi, unutma, duygularını bastırma, noksan ifadeleri tamamlama isteği, yerinde ifade verme arzusu, idrak ya da dil eksikliği gibi hususlar bağlamında tanığın bilinçsizce yanılgı içerisinde olması gündeme gelebilmektedi $r^{40} \mathrm{ki}$ bu açıdan mahkemede tamamen hatadan müreffeh tanık, bir istisna olarak görülebilir. Bu nedenle tanık ifadesinin objektif gerçeğe ulaşma bakımından ispat aracı olarak güvenilirliğine günümüzde hem şüpheyle yaklaşılmakta ${ }^{41}$ hem de tanıklık en sorunlu ispat araçlarından biri olarak nitelendirilmektedir ${ }^{42}$. Fakat bu ispat aracından da hiçbir şekilde vazgeçilememektedi $r^{43}$.

Tanık beyanı, ne olursa olsun olay yerinde tespit edilen parmak izi gibi somut bir belirtiden daha güvenilir değildir ${ }^{44}$. Bu nedenle bir kimsenin yalnızca olguları şahsen idrak etme ve bunlar üzerinde mal umat verme konumunda bulunması tanıklık için yeterli kabul edilir ve buna uygun olmak şartıyla bedensel ya da zihinsel anlamda engeli bulunan kişiler dâhil olmak üzere kural itibariyle sanık dışında herkesin tanık olabileceği kabul edilir ${ }^{45}$. Hiç kimse ilk baştan tanıklığa elverişsiz olarak nitelendirile $m^{46}{ }^{46}$. Kişinin kusur yeteneğine ilişkin durumu nedeniyle ceza sorumluluğunun bulunmuyor olması, tanıklık yapmasına engel teşkil eder bir husus değildir, bu husus tanıklık konusunda önemsizdir ${ }^{47}$. Şayet böyle bir imkân yoksa orijinal ispat araçlarının yanında tamamlayıcı değere sahip olacak şekilde

36 KUNTER, s. 634, dn. 314; FEYZİOĞLU, s. 67.

37 BADER, vor $\S 48$, kn. 1. Bununla birlikte Rogall, tanıklığın ilk hatta sübjektif, ikinci hatta ise objektif nitelik arz ettiğini, kanundaki her iki tanıklık türüne de işaret eden hükümlerin bulunduğunu belirtmiştir (ROGALL, vor $\S 48, \mathrm{kn} .8$ ).

38 HARTMANN / SCHMITT, kn. 245; TOROSLU / FEYZİŎLU, s. 209; ŞAHİN / GÖKTÜRK, s. 42; ÖZBEK / DOĞAN / BACAKSIZ, s. 587; SOYASLAN, Doğan: Ceza Muhakemesi Hukuku, 8. Baskı, Yetkin Yayınları, Ankara, 2020, s. 457; GÖKTÜRK, s. 349, 350; İNCE TUNÇER, s. 23; AYDIN, s. 69.

39 EISENBERG, kn. 1000.

40 ROGALL, vor $\S 48$, kn. 17; IGNOR / BERTHEAU, vor $\S 48$, kn. 14; MIEBACH, s. 233, 234; TOROSLU / FEYZİOĞLU, s. 209; GÖKTÜRK, S. 350. Bilinçsiz hatalı ifade vermenin farklı nedenleri üzerine bkz. NESTLER, Nina: "Wer einmal lügt, dem glaubt man nicht...' - Falschaussage, Glaubhaftigkeit, Lügendetektor", Juristische Arbeitsblätter (JA), 2017, s. 10-16.

41 GERCKE, vor § 48, kn. 1; ROXIN / SCHUNEMANN, § 26, kn. 1; IGNOR / BERTHEAU, vor § 48, kn. 13; TOROSLU / FEYZIOĞLU, S. 208.

42 IGNOR / BERTHEAU, vor § 48, kn. 13; MIEBACH, s. 233; GEPPERT, s. 80. Göktürk de temsil güvenilirliği açısından en çok tartış1lan ispat aracı olduğuna dikkat çekmiştir (GÖKTÜRK, s. 349).

43 FEYZIOĞLU, s. 3; GÖKTÜRK, s. 349.

44 ROXIN / SCHUNEMANN, § 26, kn. 1.

45 RGSt 42, 219 (IGNOR / BERTHEAU, vor § 48, kn. 8); BGH 01.04.1952 - 2 StR 754/51, BGHSt 2, 269 = NJW 1952, 673 (MAIER / PERCIC, vor § 48, kn. 9); VOLK / ENGLÄNDER, § 20, kn. 3; HARTMANN / SCHMITT, kn. 246; KINDHÄUSER / SCHUMANN, § 21, kn. 7; KREY / HEINRICH, kn. 1214; BADER, vor § 48, kn. 5; GERCKE, vor § 48, kn. 7; KÜHNE, kn. 802; EISENBERG, kn.

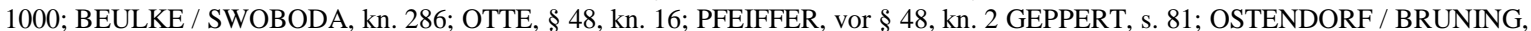
$\S 16, \mathrm{kn} .4$; ALSBERG / DALLMEYER, kn. 306; YURTCAN, s. 213; ÖZTÜRK / TEZCAN / ERDEM / GEZER / SAY GILAR KIRIT / ALAN AKCAN / TÜTÜNCÜ / ÖZAYDIN / ALTINOK VILLLEMIN / TOK, s. 301 ÜNVER / HAKERİ, s. 254; TOROSLU / FEYZİOĞLU, s. 208; CENTEL / ZAFER, s. 283; SOYASLAN, s. 457; GÖKCEN / BALCI / ALŞAHIN / ÇAKIR, 285; ÖZBEK / DOĞAN / BACAKSIZ, 585; ŞAHIN / GÖKTÜRK, s. 39; ÖZEN, Mustafa: Ceza Muhakemesi Hukuku Dersleri, 4. Baskı, Adalet Yayınevi, Anka ra, 2019, s. 319; İNCE TUNÇER, s. 24.

46 RGSt 52, 138, 139 (JOECKS, vor § 48, kn. 8; IGNOR / BERTHEAU, vor § 48, kn. 27; ROGALL, vor § 48, kn. 35); EISENBERG, kn. 1000; OTTE, § 48, kn. 16; ALSBERG / DALLMEYER, kn. 306.

47 ROGALL, vor § 48, kn. 35; ALSBERG / DALLMEYER, kn. 306; TOROSLU / FEYZİĞLU, s. 208; GÖKCEN / BALCI / ALŞAHİN / ÇAKIR, S. 285. 
dolaylı ispat araçlarının kullanılmasına müsaade edilir ${ }^{48}$. Bu çerçevede algılama yeteneğine sahip olması ve bu algıladığı hususları anlatabilecek durumda olması kaydıyla akıl hastaları ve çocuklar da tanıklık yeteneğine sahiptir ${ }^{49}$. Nitekim Yargıtay, olayı gördükleri iddia edilen kişilerin, yalnızca küçük (on veya on dört yaşlarında) olması nedeniyle tanıklık yapamayacaklarından bahisle dinlenilmeden verilen kararı eksik araştırma ve yetersiz gerekçeyle hukuka aykırı bulmuştur ${ }^{50}$.

Burada esas itibariyle Alman uygulamasında yaş konusunda bir sınır bulunmasa da ${ }^{51}$ dört buçuk yaşın altında olan çocuklar nadiren tanıklığa elverişli telakki edilmektedi $r^{52}$ ve bu çocukların ifadelerinin mutlaka bir uzman tarafindan değerlendirilmesi gerektiği ifade edilmektedir ${ }^{53}$. Dolayısıyla bu sonuç, dört buçuk yaşında ya da bu yaşın altındaki çocukların sırf yaşları nedeniyledoğrudan tanıklık yapamayacakları sonucuna ulaşılamayacağı anlamına gelmektedir ki bu çerçevede somut olaydaki çocuğun ve keza ak1l hastası olan kişinin algılama ve kendisini ifade edebilme yeteneğine bakılmalıdır ${ }^{54}$. Bu noktada ta nıklık yapacak kişinin hem ifade verilecek konuya ilişkin genel idrak durumu hem de ifade konusuyla ilişkili olarak bireysel anlamdaki yeteneği, her bir somut olay çerçevesinde hâkim ya da mahkeme tarafindan tespit edilir ${ }^{55} \mathrm{ki}$ bu nedenle tanığın huzurda bulunması beklenir, tanığa çağrı üzerine huzurda bur lunma yükümlülüğü yüklenir ${ }^{56}$. Kuşkusuz ki kişinin tanıklığa ehil olup olmadığı konusunda uzman kişinin yardımından yararlanılabilir ${ }^{57}$ ve hatta bazen yararlanılması gerekli olabilir. Nitekim Yargıtay Ceza Genel Kurulu, 1-251/454 sayılı ve 12.11.2013 tarihli kararında tanık Ö.F.T.'nin mikrosefali hastası olduğu, hastalığı nedeniyle büyüme ve gelişim geriliğinin bulunduğu anlaşıldığından kişinin tanıklığına başvurulmadan evvel Adli Tıp Kurumuna sevkinin sağlanarak hastalığı nedeniyle beyanlarına itibar edilmesinin mümkün olup olmadığı hususunda rapor aldırılması gerektiğine hükmetmiştir ${ }^{58}$.

Şayet mahkeme, kişinin tanıklık yapma konusunda yeterli olmadığı sonucuna ulaşırsa bu durumda ya kişiyi tanık olarak görevlendirmez ya da ispat aracının elverişsizliği nedeniyle kişiye ait olan ifade-

48 BVerfGE 57, 277 (EISENBERG, kn. 1031).

49 RGSt 58, 396 (ROGALL, vor § 48, kn. 37; IGNOR / BERTHEAU, vor § 48, kn. 27); BGH v. 01.04.1952 - - 2 StR 754/51, BGHSt 2, 269 (OTTE, § 48, kn. 16); BGHSt 43, 62 (KINDHÄUSER / SCHUMANN, § 21, kn. 7); BGH NStZ 2008, 116 (HARTMANN / SCHMITT, kn. 246); BEULKE / SWOBODA, kn. 286; ROXIN / SCHUNEMANN, § 26, kn. 2; KREY / HEINRICH, kn. 1214; MAIER / PERCIC, vor § 48, kn. 9; SCHMITT, vor $\S 48$, kn. 13; GLEY, Chrisra: "Psychologische Grundl agen und Kriterien der Beurteilung von Zeugenaussagen be Kinderm und J ugendlichen", Der Strafverteidiger (StV), 1987, s. 405; KÜHNE, kn. 802; JOECKS, vor § 48, kn. 8; GEPPERT, s. 81; OSTENDORF / BRUNING, § 16, kn. 4; ALSBERG / DALLMEYER, kn. 306; ÖZTÜRK / TEZCAN / ERDEM / GEZER / SAY GILAR KIRIT / ALAN AKCAN / TÜTÜNCÜ / ÖZAYDIN / ALTINOK VILLEMIN / TOK, s. 211; TOROSLU / FEYZIOĞLU, s. 208; ÖZBEK / DOĞAN / BACAKSIZ, s. 585; YURTCAN, s. 213; CENTEL / ZAFER, s. 301; SOYASLAN, s. 458; ŞAHIN / GÖKTÜRK, s. 39; GÖKCEN / BALCI / ALŞAHIN / ÇAKIR, s. 285; KARAKEHYA, s. 223; ÖZEN, s. 319; INCE TUNÇER, s. 24, 25.

50 Yargitay, 4. CD., T. 14.10.2006, E. 2005/4174, K. 2006/14805, (YURTCAN, s. 214; ÜNVER / HAKERİ, s. 257).

51 BGH NStZ 2015, 419 (BADER, vor § 48, kn. 5); EISENBERG, kn. 1002; OTTE, § 48, kn. 16; OSTENDORF / BRUNING, § 16, kn. 4; ALSBERG / DALLMEYER, kn. 306.

52 IGNOR / BERTHEAU, vor § 48, kn. 27; GERCKE, vor § 48, kn. 7; MAIER / PERCIC, vor § 48, kn. 9; SCHMITT, vor § 48, kn. 13; ROGALL, vor § 48, kn. 37; JOECKS, vor § 48, kn. 8; OTTE, § 48, kn. 16; ALSBERG / DALLMEYER, kn. 306; ARNTZEN, Friedrich: "Untere Altersgrenze der Zeugeneignung", Deutsche Richterzeitung (DRiZ), 1976, s. 20. Gley, bu sinırı dört yaş olarak belirlemiş ve bu da Alman öğretisinde yaygın şekilde kabul görmüștür. Bkz. GLEY, s. 405. Bununla birlikte Rogall, yeni deneysel araştırmalar sonucunda günümüzde normal gelişen üç yaşında çocukların da telkinlerden sakınabilecek ve makul şekilde ifade verebilecek durumda olduğunun kabul edildiği yönünde fikirlerin olduğuna işaret etmiştir (ROGALL, vor § 48, kn. 37). Türk öğretisinde Ünver / Hakeri, iki üç yaşında çocukların tanıklık yapabileceklerini belirtmiştir (ÜNVER / HAKERİ, s. 255). Bu konudaki kanaatimiz, çocukların bile her şe ye ulaşabildikleri ve birçok konuda hızla gelișim gösterdikleri günümüz bilgisayar ve teknoloji çağında çocuklar bakımından belirli bir yaş kriteri belirlemektense yavaş yavaş konuşmaya başlayan bir çocuğun dahi ifade verebilme ve ifadelerinin güvenilir olma durumunun mutlaka bir uzman tarafindan irdelenmesi ve sonrasında yapılan tespitlerin savcı, hâkim ya da mahkeme tarafından değerlendirilmesiyle birlikte çocuğun tanık olup olamayacağına karar verilmesi gerektiği yönündedir. Bu çerçevede hiç kuşkusuz ki henüz bebek durumundaki çocukların tanıklı̆̆ kabul edilemez.

53 GLEY, s. 405

54 VOLK / ENGLÄNDER, § 20, kn. 3; KREY / HEINRICH, kn. 1214; EISENBERG, kn. 1002. Nitekim Alman Federal Yüksek Mahke mesi, dört yaşında bir cocuğun ifadesinin güvenilirliğine dair bir değerlendirme yapılmadan ispat değerine sahip olmadığına ișaret etmiştir (BGH StV 1995, 293 - KÜHNE, kn. 802). Türk hukukunda çocukların tanıklık ifadesi, mümkünse yalnızca bir defa alınır ve ayrıca görüntü veya sesleri kayda alınır.

56 ALSBERG / DALLMEYER, kn. 306.

57 GERCKE, vor § 48, kn. 7; ROGALL, vor § 48, kn. 36; BADER, vor § 48, kn. 5.

58 Karar için bkz. YAŞAR, Osman: Yeni İçtihatlarla Uygulamalı ve Yorumlu Ceza Muhakemesi Kanunu, Cilt 1, 9. Baskı, Seçkin Yayıncılık, Ankara, 2020, s. 434; CENTEL / ZAFER, s. 283, dn. 109 
leri değerlendirmeye almaz ${ }^{59}$. Tanığın akı1 hastası olması durumunda ifadesinin önem derecesi itibarıyla tanığın duruşmada hazır bulunması gerekli görülmüyorsa bu kişilerin dinlenmesi yerine, daha önce yapılan dinleme sırasında düzenlenmiş tutanaklar ile kendilerinin yazmış olduğu belgeler okunabilir (CMK m 211). Yine sağır-dilsiz olduğu için normal şekilde ifade vermesi beklenemezse ifadesini gerekirse parmak işaretleriyle ve hatta mimikleriyle de vermesi kabul edilebilir ${ }^{60}$. Bunun yanı sıra mahkeme, doğrudan sözlü beyanda bulunamayacak durumda olan tanığa güvenilir bir kimseyi yardımcı olarak görevlendirebilir ${ }^{61}$. Tüm bunlara karşılık dijital asistanların tanık olamayacakları da özellikle ifade edilmelidir ${ }^{62}$. Tanığın bildiklerini doğru bir şekilde anlatması dışında bir hâkim ya da savcı gibi objektif ve tarafsız olması beklen(e)mediğinden sanığın aile üyeleri, akrabaları, ekonomik anlam da sanığa bağlı kişiler, sanığın dostu yahut hasmı konumundaki kimseler, nihayet hakkında yalan ta nıklık suçundan dolayı mahkûmiyet kararı bulunan kişiler de tanık olabilir ${ }^{63}$. Bu kişilerin ifadelerinin şüpheli olan güvenilirlik durumu tanıklık yapabilmelerinin önünde bir engel teşkil etmemekle birlikte ${ }^{64}$ kuşkusuz ki bu husus ispat araçları değerlendirilirken dikkate alınır ${ }^{65}$.

\section{B. Tanıklığın Konusu}

Tanığın görevi, dava konusu fiile ilişkin olay ve olgular üzerine beyanda bulunmaktır ki buna "tanık beyanı" adı verilir ${ }^{66}$. Bu açıdan tanıklığın konusu, kural olarak dış dünyada meydana gelen olay ve olgular ${ }^{67}$ olup kişi bunlar üzerine duyularıyla algıladığı hususları belirtir ${ }^{68}$. Bununla birlikte mahkeme huzurunda görülmesi ve tartışılması gereken bir husus söz konusu ise buna ilişkin tanıklıkla yetinilmez. Söz gelimi bir kimsenin maruz kaldığı yaralanma olayı tanıklığın konusu olabilirken kişinin vücudundaki yaralar keşif konusu olur ve bunların mutlaka yetkili makam tarafindan görülüp incelenmesi gerekir ${ }^{69}$. Tanığın ifadelerinin dava konusu olayla bağlantılı olması şartıyla ${ }^{70}$ suç teşkil eden fiilin işleniş süreci hakkında mı yoksa bunun dışında başka algılamaları üzerine mi olduğu önemsizdir. Ayrıca daha evvel ifade edildiği üzere tanığın söz konusu olay ve olgulara ne zaman ve nasıl rastladığının bir önemi bulunmayıp tanık sıfatını haiz kişi bu olay ve olgularla tesadüfen denk gelebileceği gibi kolluk görevlisi olarak meslek icabı olarak da karşılaşmış olabilir ${ }^{71}$.

59 ROGALL, vor $\$ 48, \mathrm{kn} .36$.

60 RG 33, 403 (SCHMITT, vor § 48, kn. 13); KÜHNE, kn. 802; EISENBERG, kn. 1001; KUNTER, s. 631; AYDIN, s. 67; GÖKTÜRK, s. 355, 356.

61 BGH 24.04.1997 - 4 StR 23/97, BGHSt 43, 62 =NJ W 1997, 2335 (MAIER / PERCIC, vor § 48, kn. 9).

62 Gless StV 18, 671, 673 (SCHMITT, vor $\S 48, \mathrm{kn} .1$ ).

63 ROXIN / SCHUNEMANN, § 26, kn. 2; PFEIFFER, vor § 48, kn. 2; GEPPERT, s. 81; SAHIN / GÖKTÜRK, s. 39; YURTCAN, s. 213; ÖZTÜRK / TEZCAN / ERDEM / GEZER / SAYGILAR KIRIT / ALAN AKCAN / TÜTÜNCÜ / ÖZAYDIN / ALTINOK VILLEMIN / TOK, s. 301; SOYASLAN, s. 458; GÖKCEN / BALCI / ALŞAHIN / ÇAKIR, s. 285; ÜNVER / HAKERİ, s. 255; ÖZBEK / DOĞAN / BACAKSIZ, s. 586; ÖZEN, s. 319; INCE TUNÇER, s. 25. Mecelle'de tanığın tanımı yapılmıș, yalan söylemekle bilinen kișiler tanıklık kapsamı dışında bırakılmıştır. Nitekim tanım şu şekildedir: "SSahidin âdil olması lazımdır. Âdil, hasenatı seyyiatına galip olan kimsedir. Binaenaleyh rakkas ve maskara gibi namus ve mürüvveti muhil hâl ve hareketleri i'tiyat eden eşhasın ve kîzb ile ma'ruf olan kesanın şahadetleri makbul olmaz." Bkz. KUNTER, s. 631, dn. 302.

64 KINDHÄUSER / SCHUMANN, § 21, kn. 7; ROXIN / SCHUNEMANN, § 26, kn. 2; HARTMANN / SCHMITT, kn. 246.

65 KINDHÄUSER / SCHUMANN, § 21, kn. 7; İNCE TUNÇER, s. 54.

66 SAHİN / GÖKTÜRK, s. 38.

67 Esasında Kunter, "vakıa" ifadesini kullanmısssa da (KUNTER, s. 633) biz, çalıssmamızın bașlangıcında gümümüzdeki hemen her kaynakta olduğu gibi tek başına "olgu" ifadesini tercih etmemize rağmen Araştırma Görevlisi Cafer Erdem Umudum'la yapılan fikir teatisi ne ticesinde bunun yerine "olay" ifadesini tercih etmeye karar vermiştik. Ancak daha sonra Dursun'un eserindeki olay ve olgu kavramları arasındaki açıklamalara (DURSUN, Selman: Disiplinlerarası Bir Yaklaşımla Ceza Hukukunda Hareket Kavram ve Terimi, Seçkin Ya yincilık, Ankara, 2021, 253) binaen "olay" ve "olgu" ifadelerini birlikte kullanmayı uygun gördük.

68 KÜHNE, kn. 795; JOECKS, vor § 48, kn. 2; ROGALL, vor § 48, kn. 15; MAIER / PERCIC, vor § 48, kn. 3; BADER, vor § 48, kn. 1; GEPPERT, s. 81; FEYZIOĞLU, s. 65.

69 SCHMITT, vor $\S 48, \mathrm{kn} .1$; KREY / HEINRICH, kn. 1210; MAIER / PERCIC, vor $\$ 48, \mathrm{kn}$. 1; JOECKS, vor $\S 48$, kn. 2; BEULKE / SWOBODA, kn. 286; OTTE, § 48, kn. 1; OSTENDORF / BRUNING, § 16, kn. 4; ALSBERG / DALLMEYER, kn. 303.

70 ROGALL, vor $\$ 48, \mathrm{kn} .15$.

71 BGH 33, 178 (SCHMITT, vor § 48, kn. 1); VOLK / ENGLÄNDER, § 20, kn. 3; IGNOR / BERTHEAU, vor § 48, kn. 8; JOECKS, vor § 48, kn. 2; ÖZTÜRK / TEZCAN / ERDEM / GEZER / SAY GILAR KIRIT / ALAN AKCAN / TÜTÜNCÜ / ÖZAYDIN / ALTINOK VILLEMIN / TOK, s. 301. 
Alman Ceza Muhakemesi Kanunu' nun § 85 hükmünde yer alan, “Geçmişte gerçekleşmişs olay ya da durumların algilanması özel bir bilgiyi gerektiriyor ve bunların ispat edilmesi konunun uzmanı olan kişilerin dinlenmesini gerekli killyorsa bunlar hakkında tanık beyanına ilişkin hükümler uygulanır." şeklindeki ifadeden hareketle "kural olarak" sadece geçmiş dönemdeki olay ve olgular, bilhassa da fiilin sonuçlarına ilişkin olaylar, tanık delilin konusu olarak kabul edilmektedir ${ }^{72}$. Ancak öğretide bu düzenlemeye tamanlamıyla uygun olmayacak şekilde halen devameden mevcut bir olay ya da olgu, söz gelimi süregelen olaylar ya da fiilin etkisi devam eden neticeleri üzerine tanıklık mümkün görülmektedir ${ }^{73}$. Buna göre söz gelimi sanık tarafindan uygulanan şiddetin sonucu olarak mağdurun halen acı çektiği ifade edilebilir ${ }^{74}$. Bunun yanında tanığın ifadeleri, en başta dışsal anlamda fark edilebilir olay ya da olgular üzerine olabilirken têtdidin ciddiyeti gibi konularda his ve duygularını belirtme şeklinde tanık konumındaki kişinin bilincinde gerçekleşen içsel olgular da tanık delilin konusu olabilir ${ }^{75}$. Buna karşılık başkasının yaşadığı olay nedeniyle içerisinde bulunduğu ruhsal durum içsel olgular bu kapsamda görülmemektedi ${ }^{76}$. Ancak kuşkusuz ki kastın tespitinde değerlendirmeye yarayacak şekilde dışarıdan fark edilebilir nitelikteki başkasının içsel olgula rı üzerine yapılan çıkarımlar, tanıklığın konusu olabilir" . Dolayısıyla "Onu son zamanlarda agresif olarak gördüğüm doğrudur.” şeklindeki cümle, tanıklık ifadesi olarak kabul edilebilecekken “Onu son zamanlarda agresif hale getiren şeyin ne olduğunu biliyorum" gibi bir cümle sarf edilirse başkasının iç dünyasına ilişkin bir yorum olduğundan bu durumda tanıklık rolü aşılmış olur". Her ne kadar tanığa, "Sanık, size onun kazalı bir araç olduğunu söylemiş olsaydı aracı yine de satın alır mıydınız?" şeklinde kendi bilinaine dair olmak kaydıyla varsayımsal ruhsal süreçler üzerine soru sorulabilirse de ${ }^{79}$ hiç gerçekleşmemiş bir olay üzerinden ya da sanığın bilincine dair sorular sorulamaz. Nitekimvarsayımsal ruhsal süreçler üzerine sorulan yukarıdaki soruyla birlikte tanık, içerisine düştüğü hata ileyapmış olduğu tasarruf arasındaki psikolojik nedenselliğin ispatı bağlamında sorgulanmaktadır ki böylesi bir sonya pekâlâ izin verilebilir ${ }^{30}$. Bununla birlikteifadelerin mutlak şekilde olumlu olması şart değildir. Nitekim tanık, belirli bir şeyi duymadığını ya da görmediğini yahut da olayın gerçekleşmediğini belirtiyorsa bu olumsuz yargı da tanıklık ifadesine dâhildi $r^{81}$ ve söz konusu hususun gerçekten meydana gelip gelmediği konusundaki değerlendirme yetkisi tamamen mahkemenin kendisine aittir ${ }^{22}$. Yine tanık olarak davet edilen kişinin, olayla ilgili hiçbir bilgisinin bulunmadığını belirtmesi halinde de tanıklık sıfatının devam ettiğinden söz edilir³.

Hukuki görüşlerlebirliktetecrübeden kaynaklı kişisel yorumlar, şüphe, tahmin ve ön yargılardan oluşan çıarım ve değerlendirmeler, olgu olarak nitelendirilmez ve tanıklığın konusu olamaz ${ }^{84}$. Tanık konumundaki

72 RGSt 47, 100 (ROGALL, vor § 48, kn. 11); BGH NJW 1969, 1219 (GERCKE, vor § 48, kn. 2); İNCE TUNÇER, s. 26.

73 KREY / HEINRICH, kn. 1211; VOLK / ENGLÄNDER, § 20, kn. 4; MAIER / PERCIC, vor § 48, kn. 3; OTTE, § 48, kn. 1; HEGER / POHLREICH, kn. 366a.

74 IGNOR / BERTHEAU, vor § 48, kn. 10.

75 BGHSt 23, 213 (ROGALL, vor § 48, kn. 16); MAIER / PERCIC, vor § 48, kn. 4; BADER, vor § 48, kn. 1; GERCKE, vor § 48, kn. 4; von SCHLIEFFEN, vor $\S 48$, kn. 10; OTTE, § 48, kn. 2; MICHEL, s. 1026.

76 BGH 11.09.2003 - 4 StR 139/03, NStZ 2004, 690, 691 (KREY / HEINRICH, kn. 1211; ROGALL, vor § 48, kn. 16; MAIER / PERCIC, vor § 48, kn. 5; BADER, vor § 48, kn. 1); VOLK / ENGLÄNDER, § 20, kn. 4; IGNOR / BERTHEAU, vor § 48, kn. 10; von SCHLIEFFEN, vor $\S 48, \mathrm{kn} .10$.

77 BGH 08.11.1983 - 5 StR 673/83, StV 1984, 61 (MAIER / PERCIC, vor § 48, kn. 5; SCHMITT, vor § 48, kn. 2; BADER, vor § 48, kn. 1); OLG Zweibrücken StV 1990, 440 (BADER, vor § 48, kn. 1; OTTE, § 48, kn. 2); von SCHLIEFFEN, vor § 48 , kn. 10.

78 VOLK / ENGLÄNDER, § 20, kn. 4.

79 BGHSt 23, 213 (ROGALL, vor § 48, kn. 16); IGNOR / BERTHEAU, vor § 48, kn. 10; MAIER / PERCIC, vor § 48, kn. 4; GERCKE, vor $\$ 48, \mathrm{kn} .4$; von SCHLIEFFEN, vor $\S 48$, kn. 10.

80 VOLK / ENGLÄNDER, § 20, kn. 4.

81 MAIER / PERCIC, vor § 48, kn. 6; ROGALL, vor § 48, kn. 16; VOLK / ENGLÄNDER, § 20, kn. 4; SCHMITT, vor § 48, kn. 2; ÖZTÜRK / TEZCAN / ERDEM / GEZER / SAY GILAR KIRIT / ALAN AKCAN / TÜTÜNCÜ / ÖZAYDIN / ALTINOK VİLLEMIN / TOK, s. 213; GERCKE, vor § 48, kn. 4; OTTE, § 48, kn. 2.

82 BGH 06.07.1993 - 5 StR 279/93, BGHSt 39, 251 =NJW 1993, 2881 (MAIER / PERCIC, vor § 48, kn. 6).

83 FEYZİOĞLU, s. 29.

84 RGSt 57, 412 (KREY / HEINRICH, kn. 1212; IGNOR / BERTHEAU, vor § 48, kn. 9; BADER, vor § 48, kn. 1); EISENBERG, kn. 1003; JOECKS, vor § 48, kn. 2; SCHMITT, vor § 48, kn. 2; VOLK / ENGLÄNDER, § 20, kn. 4; HARTMANN / SCHMITT, kn. 246; ROGALL, vor § 48, kn. 17; MAIER / PERCIC, vor § 48, kn. 3; GERCKE, vor § 48, kn. 3; BEULKE / SWOBODA, kn. 286; von SCHLIEFFEN, vor $\S 48$, kn. 10; OTTE, $\S 48$, kn. 2; PFEIFFER, vor $\S 48$, kn. 1; GEPPERT, s. 81; KUNTER, s. 633; FEYZİĞLU, s. 72; 
kişi, bu tür sorulara cevap vermekten kaçınabilir ${ }^{85}$. Kuşkusuz ki tanıklık ifadesinde kurala uygun şekilde belli oranda değerlendirici cümleler kaçınılmazdır ve bu noktada kullanılan ifadelerin içeriği noktasında ince bir sınır çekilmelidir ki bu o kadar kolay değildir ${ }^{86}$. Zira tanıklık ifadesinde her insana doğal şekilde anlaşılan ve salt algıların yanında söz gelimi fiilin işlendiği esnada havanın aydınlık olduğu, kişinin kendini kaybetmişçe sine sarhoş olduğu, "gitme" eyleminde olay açısından belirleyici olarak şoförün aracı hızlı sürdüğü gibi ola ya dair resmin ortaya çıkartılmasına etki eden çıkarımlar, olayın aydınlatılması bakımından gerekli görülebilir ve tanıklı̆̆ın konusu olabilir ${ }^{87}$. Bu bağlamda tanık, failin sarf ettiği sözleri belirtecek, ancak bu sözlerin hakaret teşkil ettiğini ifade etmeyecektir ${ }^{88}$. Kuşkusuz ki bu sözlerin hakaret teşkil edip etmediği noktasında takdir hakkı, yetkili merciye ait olacaktır. Bunun yanında Alman mahkeme kararlarında tanığın kişiler ara sında gönül ilişkisinin bulunduğu ya da evlilik ilişkisine aykırı gizli bir ilişkinin ${ }^{89}$ yahut hizmetten kaynaklı zorlama etkisinin ${ }^{90}$ söz konusu olduğu yönündeki beyanlar, tanık ifadesi olarak kabul edilmiştir. Keza olayın esasının izahında satıcı, borç, kira, mülkiyet, hırsızlık, azmettirme ya da yardım etme gibi basit hukuki kavramların kullanılmasına müsaade edilebilir ${ }^{91}$. Bununla birlikte söz gelimi uygulamada sıklıkla ariyet hakkı ile kira gibi basit hukuki kavramların karıştırılması durumu söz konusu olduğundan bu türden hukuki kavramlardan birini kullanan tanığa, bu kavramdan ne anladığı sorulabilir ${ }^{92}$ ve hatta olayın daha iyi bir şekilde açıklığa kavuşturulması bakımından mutlaka sorulmalıdır. Burada bu kavramların olayın esasını özetleyici şekilde tanımlanması ve fakat hukuki değerlendirme ve görüş yapmak için kullanılmaması gerektiği hususur na özellikle dikkat edilmelidir ${ }^{93}$. Bu çerçevede tanık, daha evvel ifade edildiği üzere olayla bağlantılı olacak şekilde "çakırkeyif" ya da "sarhoş" gibi sanığın alkol derecesine dair basit değerlendirmelerde bulunabilirse de kusur yeteneği üzerinebir yorumda bul unamaz ${ }^{94}$. Tanık, ancak sanığın ya da mağdurun kusur yeteneğinin mahkeme tarafindan değerlendirilmesine yardımcı olabilecek nitelikteki olay ve olgular hakkında bilgi vere bilir ${ }^{95}$. Kuşkusuz ki tanıklık görevini yerine getiren bir kimse, bu tarz tanıklık görevini aşar tarzda beyanlarda bulunursa mahkemenin görevlerinden biri de bunları ayırmaktır ${ }^{96}$ ve hukuki değerlendirme yaparken dikkate almamaktır ki bu konudaki takdir, tamamen mahkemeyeaitiri ${ }^{97}$.

Bu çerçevedeson olarak sanığın imajı, genel karakteri ve yaşam tarzı hakkındaki ifadelerin ne ölçüde tanık ifadesi olarak görülebileceği açıklığa kavuşturulmalıdır. Kural olarak ister istemez soyut ve olayla olgulardan az çok uzaklaşan değerlendirmelerin tanık ifadesi olarak kabul edilmesine müsaade edilmeme lidir. Bununla birlikte dava konusu olayla bağlantılı olmak ve tanığın belirttiği olguları desteklemek koşut luyla tanıklık yapan kişinin, sanığın birdenbire nasıl zengin olduğu ya da şan, şöhret sahibi olduğunu anlattığı beyanları da hukuki değerlendirmenin yapılması esnasında pekâlâ dikkate alınabilir ${ }^{98}$. Burada tanık

GÖKCEN / BALCI / ALSAHİN / CAKIR, s. 287; AYDIN, s. 69; ÖZTÜRK / TEZCAN / ERDEM / GEZER / SAY GILAR KIRIT / ALAN AKCAN / TÜTÜNCÜ / ÖZAYDIN / ALTINOK VILLEMIN / TOK, s. 213; CENTEL / ZAFER, s. 303; ÖZBEK / DOĞAN / BACAKSIZ, s. 587; GÖKTÜRK, s. 357. IGNOR / BERTHEAU, vor $\$ 48, \mathrm{kn}$. 11; EISENBERG, kn. 1003. CENTEL / ZAFER, s. 283, 284. Aksi görüs icin bkz ÖZTÜRK TEZCAN / ERDEM / GEZER / SAYGILAR KIRIT / ALAN AKCAN / TÜTÜNCÜ / ÖZAYDIN / ALTINOK VILLEMIN / TOK, s. 303; ÖZBEK / DOĞAN / BACAKSIZ, s. 587.

88

89 OLG Oldenburg NdsRpfl. 1950, 163 (ROGALL, vor $\S 48$, kn. 18).

90 RG JW 1925, 998 (ROGALL, vor § 48, kn. 18).

91 RG Recht 1922 Nr. 359 (IGNOR / BERTHEAU, vor § 48, kn. 11); BGH v. 04.05.1951 - 4 StR 216/51, BGHSt 1, 137 (ROGALL, vor § 48, kn. 19; OTTE, § 48, kn. 4); MAIER / PERCIC, vor § 48, kn. 8; SCHMITT, vor § 48, kn. 4; GERCKE, vor § 48, kn. 6. 
konumundaki kişinin esasen değer yargısı içeren bu ifadelerinin, herhangi bir özel uzmanlık gerektirmeme si veözellikle önceki bul gulara, ortaya konulan somut olgusal gerçeklere dayanarak olayın esasını açıklığa kavuşturması bağlamında işlevsel ve doğrulanabilir olması önem arz etmektedir ${ }^{99}$. Ayrıca bu şekildeki ifadelerin başka delillerle desteklenmesi ve tanığın olay ve olgulara ilişkin beyanlarını detaylandırması gerekli olacaktır ki ancak bu koşullar altında kişinin karakter özellikleri hakkında beyanda bulunulması tanıklık ifadesi altında nitelendirilebiliir ${ }^{100}$. Bu çerçevede Alman mahkeme kararlarında kişinin güvenilir ${ }^{101}$, yalancı ve ahlaksız ${ }^{102}$, şöhret sahibi ${ }^{103}$, konuşkan ${ }^{104}$ olduğu yönündeki ifadeler, somut olay ve ol gulara ilişkin değerlendirmelere bağlı olmak kaydıyla tanıklık ifadesi kapsamında nitelendirilmiştir ${ }^{105}$.

\section{MUHAKEMEYE KATILAN SÜJELERİN TANIK OLUP OLAMAYACAKLARI SORUNU}

Tanıklık kavramı ve tanıklığın konusuna değindikten sonra incelemenin esasına geçiş yapılabilir. Mur hakemede iddia, savunma ya da yargilama görevini yerine getiren ve bu makamlarda yer alan kişiler, mur hakeme sürecine katılan tanık dışındaki süjeler olarak nitelendirilebilir ${ }^{106}$. Bunlar; hâkim, savcı, müdafi, katılan, müdafi, sanık, zabit kâtibi, bilirkişi gibi muhakemeiçerisindeherhangi bir sıfatla rol alan kişilerdir. İşte bu kimselerin, muhakeme içerisinde tanık olarak dinlenmeleri, "rol çatışması" sonucunu beraberinde getirir ${ }^{107}$ ki bu durum, bilhassa da yargılamayı yürüten hâkimin tanıklık yapmasında belirgin bir şekilde kendisini gösterir ${ }^{108}$. Bu bakımdan muhakemeye herhangi bir sıfatla katılan kişilerin bu muhakeme içerisindehangi koşullar altında tanıklık yapabilecekleri sorunu ortaya çıkar ki esasen çalışmamızın temel konusu budur. Bu çerçevede muhakemeye katılan süjeleri ayrı ayrı irdelemektefayda görmekteyiz.

\section{A. Hâkim}

Bir kimse, aynı dava konusu olaya ilişkin olarak aynı zamanda hem tanıklık hem hâkimlik yapamaz, bu iki muhakeme süjesinin birbiriyle uyumundan söz edilemez ${ }^{109}$. Bununla birlikte kuşkusuz ki tanıklık yapma yükümlülüğü, hâkimlik görevinden önce gelir ${ }^{110}$. Zira olaya dair olay ve olguları idrak eden ve olayı aydınlatmaya yarayacak ifadeleri verebilecek başka bir tanığın bulunamayabilecek olması ve hatta bulunsa bile her bir tanığın ifadesinin birbirinden bağımsız olarak olayı aydınlatma noktasında ayrı önemi haiz olması söz konusuyken davaya pekâlâ başka bir hâkimin bakma sından söz edilebiliri"11. Bu açıdan bir hâkimin görev yaptığı bir dava konusu olay bakımından tanıkl1k yapması gerekiyorsa şüphesiz ki bu, mümkündür ${ }^{112}$ ve hatta bunun ötesinde gereklidir. Ancak

99 MAIER / PERCIC, vor § 48, kn. 3; IGNOR / BERTHEAU, vor § 48, kn. 12; ROGALL, vor § 48, kn. 20; WIDMAIER, Gunter: “Anforderungen an Beweisantrag", Neue Zeitschrift für Strafrecht (NStZ), 1993, s. 602, 603; SCHMITT, vor § 48, kn. 3; FEYZİĞLU, 79.

100 ROGALL, vor $\S 48$, kn. 20, FEYZİĞLU, s. 79.

101 RGJW 1930, 760 (ROGALL, vor § 48, kn. 20; IGNOR / BERTHEAU, vor § 48, kn. 12; BADER, vor § 48, kn. 1; EISENBERG, kn. 1003).

102 RGSt 37, 371, 372 (IGNOR / BERTHEAU, vor § 48, kn. 12; ROGALL, vor § 48, kn. 20; BADER, vor § 48, kn. 1; EISENBERG, kn. 1003).

103 RGSt 26, 70 (IGNOR / BERTHEAU, vor § 48, kn. 12; BADER, vor § 48, kn. 1); RG HRR 1933, 1059 (ROGALL, vor $\S 48, k n .20$ ).

104 RG HRR 19331059 (IGNOR / BERTHEAU, vor § 48, kn. 12).

105 OTTE, § 48, kn. 3; SCHMITT, vor § 48, kn. 3.

106 FEYZİOĞLU, s. 32.

107 KINDHÄUSER / SCHUMANN, § 21, kn. 8; HARTMANN / SCHMITT, kn. 248; OSTENDORF / BRUNING, § 16, kn. 5.

108 HARTMANN / SCHMITT, kn. 248.

109 BGHSt 7, 44 (BADER, vor $\S 48$, kn. 10; GERCKE, vor $\S 48$, kn. 9; HOLTZ, Günter: "Aus der Rechtsprechung des Bundesgerichtshofs in Strafsachen", Monatsschrift für Deutsches Recht (MDR), 1977, s. 107); ROGALL, vor § 48, kn. 47; MICHEL, s. 1026; ALSBERG / DALLMEYER, kn. 309; HOLTZ, s. 107; FEYZIOĞLU, s. 61; CENTEL, Nur: Ceza Muhakemesi Hukukunda Hâkimin Tarafsızlı̆̆, Kazancı Yayınları, İstanbul, 1996, s. 70; CENTEL / ZAFER, s. 284; GÖKCEN / BALCI / ALŞAHİN / ÇAKIR, s. 286; KARAKEHYA, s. 224.

110 ROXIN / SCHUNEMANN, § 26, kn. 6; KÜHNE, kn. 805; ROGALL, vor § 48, kn. 48; MICHEL, s. 1026; YURTCAN, s. 213; GÖKCEN / BALCI / ALŞAHIN / ÇAKIR, s. 286; ŞAHIN / GÖKTÜRK, s. 40; ÖZTÜRK / TEZCAN / ERDEM / GEZER / SAYGILAR KIRIT / ALAN AKCAN / TÜTÜNCÜ / ÖZAYDIN / ALTINOK VİLLEMIN / TOK, s. 302; ÖZBEK / DOĞAN / BACAKSIZ, s. 587; ÜNVER / HAKERİ, s. 256; ÖZEN, s. 320.

111 MICHEL, s. 1026; ÖZTÜRK / TEZCAN / ERDEM / GEZER / SAYGILAR KIRIT / ALAN AKCAN / TÜTÜNCÜ / ÖZAYDIN / ALTINOK VİLLEMIN / TOK, s. 212; SOYASLAN, s. 458; GÖKCEN / BALCI / ALŞAHİN / ÇAKIR, s. 286 ; ÖZEN, s. 320.

112 SCHMITT, vor § 48, kn. 15; ALSBERG / DALLMEYER, kn. 309; IGNOR / BERTHEAU, vor § 48, kn. 39; EISENBERG, kn. 1007; JOECKS, vor $§ 48$, kn. 9; BEULKE / SWOBODA, kn. 287; ŞAHIN / GÖKTÜRK, s. 40. 
dava konusu olayda tanık olarak ifade veren hâkim, kanuni düzenleme nedeniyle aynı olayın konu olduğu yargılamada hâkimlik görevinde bul unamayacağından görevinden çekilir (CMK m 22/1-h; AlmCMK § $22 \mathrm{Nr}$. 5) ve bu hâkimin yerine başka bir hâkim geçer, bu durumda söz konusu hâkim görevinden çekinmezse reddi istenebilir (CMK m 24/1, 2; AImCMK § 24 I) ${ }^{113}$. Burada hâkimin muhakemenin herhangi bir aşamasında yetkili merciler tarafından kişisel olarak olayın esasına dair tanık sıfatıyla beyanına "başvurulmuş olması" yeterlidir114. Her iki kanun koyucu da bir olayla ilgili olarak tanık sıfatıyla ifade veren hâkimin daha sonradan bu olay bakımından kendi ifadeleriyle uyumlu olmayacak şekilde, nesnel ve gerçeğe uygun bir değerlendirme yapamayacağı, bunun oldukça zor olacağı yönündeki karineden hareket etmiştir ${ }^{115}$. Nitekim duruşma esnasında tanık olarak beyan ettiği cümlelerin bir kısmının doğru olmadığı yönünde ileri sürülen bir iddia, ister istemez hâkimin kendi șahsına yönelik olarak algılayabileceği bir husus olabilir ve bu da objektif duruşuna halel getirebilir. Elbette bu şekilde bir kural, sadece psikolojik imkânsılılıtan değil, aynı zamanda bu muhakeme rollerinin ve fonksiyonlarının farklı işleve sahip olmasından da kaynaklanmaktadır. Bu çerçevede muhakemenin süjesi olarak objektif konumda bulunan hâkimin konumu ve görevi, bir ispat aracı olarak tanığın fonksiyonlarıyla uyuşmaz ${ }^{116}$. Dolayısıyla bir kimsenin tanıklık yaptığı olayda hâkimlik yapamayacağı yönündeki bu kural, aynı fiili olaya ilişkin başka bir davada tanıklık yapılması durumunda da geçerli görülürr17.

Bu noktada bir hâkimin tanık olarak kabul edilme ihtimalinin, tek başına hâkimi tanık haline getirme yeceği belirtilmelidir ${ }^{118}$. Zira hemCMK hükmünde ( $m$ 22/1-h) hem de AImCMK hükmünde (§ $22 \mathrm{Nr}$. 5) açıkça hâkimin tanık olarak "dinlenmiş olmasından" söz edilmektedir ${ }^{119}$. Bu nedenle bir hâkimin duruşma da tanıklığının talep edilmesi ya da hâkimin bu şekilde isimlendirilmesi, bu davadan çekinmesini gerektirmese de ${ }^{20}$ kuşkusuz ki reddi yönünde bir talep için temel oluşturabiliir ${ }^{121}$. Nitekim hâkim, ispat sorunuyla ilgili hiçbir bilgisi olmadığını belirtebilir ve bu bakımdan tanıklık yapması yönündeki talep uygun görülmeyebilirr22. Aksi durumda sanık, sırf hâkim konumundaki kişinin hâkimlik sıfatını sona erdirmek ya da yargılamayı sürüncemede bırakmak için hâkimin tanıklık yapması talebinde bul unma girişiminde bul unabilir ${ }^{223}$ ki bu tür kötüye kullanımların önüne geçmek adına hâkimin görevli sıfatıyla ispat konusu olayla ilgili

113 BGH StV 1991, 99 (JOECKS, vor § 48, kn. 9); GERCKE, vor § 48, kn. 9; KÜHNE, kn. 805; IGNOR / BERTHEAU, vor § 48, kn. 39; ROGALL, vor § 48, kn. 48; EISENBERG, kn. 1007; von SCHLIEFFEN, vor § 48, kn. 30; OTTE, § 48, kn. 17; PFEIFFER, vor § 48, kn. 2; GEPPERT, s. 86; ALSBERG / DALLMEYER, kn. 309; OSTENDORF / BRUNING, § 16, kn. 6; HEGER / POHLREICH, kn. 366a; MICHEL, s. 1026; CENTEL, s. 70; FEYZIOĞLU, s. 61; CENTEL / ZAFER, s. 284; ÜNVER / HAKERİ, s. 256; ÖZTÜRK / TEZCAN / ERDEM / GEZER / SAYGILAR KIRIT / ALAN AKCAN / TÜTÜNCÜ / ÖZAYDIN / ALTINOK VILLLEMIN / TOK, s. 302; YURTCAN, s. 213; SOYASLAN, s. 458; ŞAHIN / GÖKTÜRK, s. 40; GÖKCEN / BALCI / ALŞAHIN / ÇAKIR, s. 286; YAŞAR, C. I, s. 419; ÖZBEK / DOĞAN / BACAKSIZ, s. 587; KARAKEHYA, s. 224; ÖZEN, s. 320.

114 EISENBERG, kn. 1008; CENTEL, s. 70.

115 ROGALL, vor § 48, kn. 47; IGNOR / BERTHEAU, vor § 48, kn. 39; MICHEL, s. 1026; CENTEL / ZAFER, s. 284.

116 ROGALL, vor § 48, kn. 47; GEPPERT, s. 86; FEYZİĞLU, s. 61; ÖZEN, s. 320.

117 BGHSt 31, 358 (KÜHNE, kn. 805).

118 BGHSt 11, 206 =NJW 1958, 557 (ALSBERG / DALLMEYER, kn. 309); OTTE, § 48, kn. 17; IGNOR / BERTHEAU, vor § 48, kn. 39; MICHEL, s. 1026; HOLTZ, s. 107; KÜHNE, kn. 805; CENTEL, s. 70; CENTEL / ZAFER, s. 284.

119 Esasen Feyzioğlu, kanuni tanımda yer alan bu ifadeyi eleștirmekte, hâkimin tarafsızı̆̆ı̆ı bozan hususun hâkimin tanık olarak dinlenme si değil, olaya tanık olması durumu olduğunu ifade etmektedir (FEYZİOĞLU, s. 62).

120 BGHSt 11, 206; BGHSt 14, 219 (ROGALL, vor § 48, kn. 48); BGHSt 7, 44 (von SCHLIEFFEN, vor § 48, kn. 30); GERCKE, vor § 48, kn. 9; BADER, vor § 48, kn. 10; MAIER / PERCIC, vor § 48, kn. 10; IGNOR / BERTHEAU, vor § 48, kn. 39; MICHEL, s. 1026; GEPPERT, s. 87; EISENBERG, kn. 1008; JOECKS, vor § 48, kn. 9; CENTEL, s. 70; CENTEL / ZAFER, s. 284. NitekimAskeri Yargitay, 96/94 sayılı ve 10.12.1971 tarihli kararında, "hâkim aynı davada tanık sıfatı ile dinlenmiş ise o davaya bakamaz, bu hal hâkim için bir yargı yasağı teşkil eder. Ancak hâkim yönünden bu yasak, tanık olarak dinlenme ile başlar. Bu bakımdan tanık olarak çağrılmış veya görev icabı yazılı bir bildirimde bulunmuş olan hâkim için yargılama yasağı söz konusu olmaz" ifadelerine yer vermiștir. Karar için bkz. CENTEL, s. 71; CENTEL / ZAFER, s. 284, dn. 114.

121 MICHEL, s. 1026; CENTEL, s. 70; CENTEL / ZAFER, s. 284

122 BGH 7, 330 (SCHMITT, vor § 48, kn. 15; IGNOR / BERTHEAU, vor § 48, kn. 39); EISENBERG, kn. 1008a; JOECKS, vor § 48, kn. 9; KÜHNE, kn. 805; BEULKE / SWOBODA, kn. 287; ÖZTÜRK / TEZCAN / ERDEM / GEZER / SAY GILAR KIRIT / ALAN AKCAN / TÜTÜNCÜ / ÖZAYDIN / ALTINOK VILLEMIN / TOK, s. 302; GÖKCEN / BALCI / ALSAHIIN / CAKIR, s. 286; FEYZIOĞLU, s. 63.

123 RGSt 42, 2 (BADER, vor § 48, kn. 10); BGH 07.12.1954 - 2 StR 402/54, BGHSt 7, 44 =NJW 1955, 152 (MAIER / PERCIC, vor $\S 48$, kn. 10); EISENBERG, kn. 1008; MICHEL, s. 1026; HOLTZ, s. 107; BEULKE / SWOBODA, kn. 287; CENTEL, s. 71. 
hiçbir bilgisinin olmadığını beyan etmesi halinde bu şekildeki talebin reddi uygun görülmektedir ${ }^{124}$. Bu açıdan kendisinin tanıklık yapması talebi söz konusu olan hâkimin kendisi de bu konuda verilecek karara katılır ve bu konudaki görüşünü beyan eder (CMK m 31/2; AlmCMK § 26a II) ${ }^{125}$. Alman öğretisinde bir görüş ${ }^{126}$, hâkimin tanıklık görevinde bulunması gerektiği sonucuna ulaşması halinde çağrıyı takiben, $\mathrm{o}$ andan itibaren hâkimlik görevinin sona ereceğini ileri sürmekteyse de bu görüş gerek Türk gerekse Alman kanuni düzenlemelerine uygun görünmemektedir. Zira Ceza Muhakemesi Kanunu’ nda yer alan "Hâkim, tarafsızlı̆̆ını şüpheye düşürecek sebepler ileri sürerek çekindiğinde, merci çekinmenin uygun olup olmadlğına karar verir. Çekinmenin uygun bulunması halinde, davaya bakmakla bir başka hâkim veya mahkeme görevlendirilir." şeklindeki hüküm (m 30/2) ve keza Alman Ceza Muhakemesi Kanunu' ndaki "Ret dilekçesi hakkında karar vermeye yetkili mahkeme, böyle bir talep yapılmamış olsa bile hâkimin kendisinin reddedilmesini gerektiren durumun varlı̆̆ını bildirmesi ya da başka bir sebeple hâkimin yargılamadan yasaklanmış bulunduğundan şüphe duyulması halinde bu konuda bir karar vermeye mecburdur." şeklindeki hüküm gereğince tanık olarak ifade vermesini gerekli gören hâkimin bir çekinme bildiriminde bulunma sıyla ve bu gerekçeli bildirimi üzerine gerekli kararın verilmesiylebirliktehâkimlik görevi sona erer ${ }^{127}$.

Mevcut yargılamayla ilgili olarak meslek dışında edindiği bilgiler üzerine sorulmaksızın ispat olgusu üzerine beyanda bulunan hâkimin artık tanıklık yönü öne çıkar ve bu durumda hâkim, devam eden duruşmalarda görev almamalıdır ${ }^{128}$. Bununla birlikte hâkimin tanıklık yapmak üzere çağrı üzerine esas duruşmaya çıkmış olması ancak örneğin tanıklığının reddedilmesi nedeniyle bu görevi yerine getirememiş olması, dava konusu olay bakımından hâkimlik görevini yerine getirmesine engel teşkil eder ${ }^{22}$. Buna karşı1ık bir hâkimin devam eden yargılamaya ilişkin olarak yahut halen görülmekte olan duruşma esnasında görevinden kaynaklı olay ve olgulara ilişkin edindiği algı ve izlenimler üzerine duruşmada izin verildiği ölçüde kullandığı ifadeler, meslek bilgisi olarak adlandırılır ve yargılamadan çekinmesini ya da reddedilmesini gerekli kılmaz ${ }^{130}$. Hâkimin devam eden yargılamada mesleki bilgi dışında idrak ettiği ispat olguları söz konusu olursa mesleki açıklamada bulunması mümkün değildir. Nitekim daha evvel belirtildiği üzere hâkimin, aynı konuya dair başka bir yargılamada ifadesinin alınması halinde hâkimlik görevinden çekinmesi ve bu yargılamada tanık olarak davet edilmesi gerekir ${ }^{131}$. Bir tanık, hâkimi adliyedeki odasında ziyaret eder ve hâkime karşı suçun işleniş süreci hakkında bilgi vermeye başlarsa hâkim tarafından bu türden bir konuşma esnasında idrak edilen hususlar, görev icabı kabul edilir ve bunlar hâkimin mesleki ifadeleri üzerinden esas duruşmada ortaya konulabilir. Böyle bir durumda hâkimin tanık sıfatıyla ifade vermesine yönelik talep, delillerin doğrudanlığı ilkesine aykırılık teşkil eder ${ }^{132}$. Buna göre bir tanığın hâkimin odasına gelerek az önce gerçekleşmiş dur ruşmada yalan beyanda bulunduğu itirafinda bulunması, hâkimin bu yargılamada tanık olarak görev yapmasını gerekli kılmayacak, bu olayı haber alan sanık müdafinin hâkimin tanıklık yapması yönündeki talebi reddedilecektir. Ancak hâkim, tanığın söz konusu beyanlarını bir sonraki duruşmada gündeme getirebilir, tutanağa geçirtebilir ve fakat bu bilgilere dayanarak hüküm veremez (CMK m 217), yalnızca bu bilgilere dayalı olarak yeni delil araştırmasına karar verebili $r^{133}$.

124 BGHSt 7, 330 (ROGALL, vor § 48, kn. 48; BEULKE / SWOBODA, kn. 287; ROXIN / SCHUNEMANN, § 26, kn. 6); ALSBERG / DALLMEYER, kn. 309.

125 BGHSt 11, 206 (ROGALL, vor § 48, kn. 49); EISENBERG, kn. 1008.

126 AG Brandenburg 14.10.2007 - 24 Ds 426J s 1848/07, StrFo 2007, 501 (MAIER / PERCIC, vor § 48, kn. 10); OTTE, § $48, \mathrm{kn} .17$.

127 BGH 10.09.1976 - 5 StR 215/76, MDR 1977, 107 (MAIER / PERCIC, vor § 48, kn. 10); BADER, vor § 48, kn. 10; IGNOR / BERTHEAU, vor $\S 48, \mathrm{kn} .39$.

128 RG 26, 272 (EISENBERG, kn. 1010); IGNOR / BERTHEAU, vor § 48, kn. 39.

129 BGHSt 7, 44 (BADER, vor § 48, kn. 10; von SCHLIEFFEN, vor § 48, kn. 30); MAIER / PERCIC, vor § 48, kn. 10.

130 BGHSt 39, 239 (BEULKE / SWOBODA, kn. 287; IGNOR / BERTHEAU, vor § 48, kn. 39); ÖZTÜRK / TEZCAN / ERDEM / GEZER / SAY GILAR KIRIT / ALAN AKCAN / TÜTÜNCÜ / ÖZAYDIN / ALTINOK VILLEMIN / TOK, s. 302; CENTEL / ZAFER, s. 284; GÖKCEN / BALCI / ALŞAHIN / ÇAKIR, s. 286.

131 BGHSt 31, 358 (IGNOR / BERTHEAU, vor § 48, kn. 39; ROGALL, vor § 48, kn. 49; von SCHLIEFFEN, vor § 48, kn. 30).

132 BGH 23.06.1993 - 3 StR 89/93, BGHSt 39, 239 =NJ W 1993, 2758 (MAIER / PERCIC, vor § 48, kn. 11); CENTEL / ZAFER, s. 284.

133 CENTEL / ZAFER, s. 284; ÖZEN, s. 320. 


\section{B. Cumhuriyet Savcisı}

Tanık olarak ifade veren hâkimin, aynı olayın konu olduğu yargılamada hâkimlik görevinde bulunamayacağından görevinden çekileceğine dair hüküm, soruşturmayı yürüten Cumhuriyet savcısı ba kımından geçerli değildir ${ }^{134}$. Bununla birlikte savcılar açısından gerek Ceza Muhakemesi Kanunu'nda gerekse Alman Ceza Muhakemesi Kanunu' nda hâkimin reddine benzer nitelikte bir hüküm yer al mamaktaysa da adil yargılama ilkesinden hareketle savcının kendisinin ilgilisi olduğu bir olayda savcı olarak hareket edemeyeceği sonucuna ulaşılmaktadır ${ }^{135}$. Keza Türk öğretisinde, Ceza Muhakemesi Kanunu' nda yer alan "Cumhuriyet savcısı, maddî gerçeğin araştırılması ve adil bir yargılamanın yapılabilmesi için, emrindeki adlî kolluk görevlileri marifetiyle, şüphelinin lehine ve aleyhine olan delilleri toplayarak muhafaza altına almakla ve şüphelinin haklarını korumakla yükümlüdür." şeklindeki hükmün, savcıyı hâkimin konumuna yaklaştırdığına dikkat çekilmiştir ${ }^{136}$. Bu çerçevede hâkimde belirtilen nedenlere benzer olarak Savcılıkla tanıklık görevinin kural olarak birbiriyle uyuşmadığı belirtile bilir ${ }^{137}$. Nitekimiddianame hazırlayan ve her ne kadar lehe olan delilleri de toplamasi gerekse dahi en nihayetinde sanıklar hakkında belirli ithamlarda bulunan, bu kapsamda aleyhe delillere de yer veren ve bu tanıklık ifadeleri üzerinde bir değerlendirme yapan ${ }^{138}$ muhakeme süjesi Cumhuriyet savcısının ka nuni görevleri ve fonksiyonu, bir ispat aracı olan tanığın yükümlülükleriyle uyumlu görünmemektedir. Buna rağmen şüphesiz ki kendisine karşı yargılama yürütülmeyen herkes tanık olabileceğinden bir savcının dava konusu olayla ilgili olay ve olgular üzerine bilgisi olduğunda tanıklık yapması mümkündür ve hatta zorunludur ${ }^{139}$. Savcının tanıklık yapması gerektiğinde tanıklık önceliklidir ve söz konusu savcı, daha önceki duruşmalardan birine katılmış olsa bile tanıklık yapabilir ${ }^{140}$. Bununla birlikte Savcının duruşmalardan birinde salt tanık olarak isimlendirilmesi, tanık olması gerektiğinin belirtilme si, savcıyı hemen tanık haline getirmez, dolayısıyla da bu durum hemen savcılık görevinin sona ermesine neden olmaz ${ }^{141}$. Y ine müdafinin esasa ilişkin sorusunun yanıtlanması, savcıyı tanık haline getir$\mathrm{mez}^{142}$.

Savcı, savcılık görevini üstlendiği olaya ilişkin yargılamada tanık olarak dinlenebilirse de aynı oturumda kesintisiz şekilde görevini ifa etmesi gerektiğinden duruşma içerisinde hem savcılık hem tanıklık görevini üstlenemez, kendisi tanıklık yaparken mutlaka o esnada başka bir savcı, savcılık görevini üstlenmiş olmalıdır ${ }^{143}$, aksi takdirde mahkeme teşekkül etmemiş olacağ 1 için mutlak bozma

134 OSTENDORF / BRUNING, § 16, kn. 7; HEGER / POHLREICH, kn. 366a; MOSBACHER, Andreas: "Aktuelles Strafprozessrecht”, Juristische Schulung (JuS), 2019, s. 131; FEYZIOĞLU, s. 56; CENTEL / ZAFER, s. 285.

135 IGNOR / BERTHEAU, vor $\S 48$, kn. 41. Aksi görüş için bkz. KARAKEHYA, s. 224.

136 ÖZTÜRK / TEZCAN / ERDEM / GEZER / SAY GILAR KIRIT / ALAN AKCAN / TÜTÜNCÜ / ÖZAYDIN / ALTINOK VILLLMIN /TOK, s. 302.

137 ROGALL, vor § 48, kn. 51; MOASBACHER, s. 131; ÜNVER / HAKERİ, s. 256; SOYASLAN, s. 458. Karakehya, tanıklığın savcının tarafsızlığını etkileyecek bir husus olduğu yönündeki fikri yersiz olarak nitelendirmektedir (KARAKEHYA, s. 224).

138 KÜHNE, kn. 806.

139 MAIER / PERCIC, vor § 48, kn. 14; EISENBERG, kn. 1017; BEULKE / SWOBODA, kn. 288; OTTE, § 48, kn. 19; GEPPERT, s. 87; OSTENDORF / BRUNING, § 16, kn. 7; DOSE, Norbert: "Der Sitzungsvertreter und der Wirtschaftsreferent der Staatsanwaltschaft als Zeuge in der Hauptverhandlung", Neue Juristische Wochenschrift (NJW), 1978, s. 349; FEYZİOĞLU, s. 56; ŞAHIN / GÖKTÜRK, s. 40; CENTEL / ZAFER, s. 285; KARAKEHY A, s. 224; ÖZEN, s. 321.

140 OLG Celle v. 05.07.1983 - 1 Ss 214/83, NStZ 1984, 316 OTTE, § 48, kn. 19; SCHMITT, vor § 48, kn. 17; BADER, vor § 48, kn. 11); GERCKE, vor § 48, kn. 9; IGNOR / BERTHEAU, vor § 48, kn. 41; JOECKS, vor § 48, kn. 10; von SCHLIEFFEN, vor § 48, kn. 29; GEPPERT, s. 87; OSTENDORF / BRUNING, § 16, kn. 7; HEGER / POHLREICH, kn. 366a; ŞAHIN / GÖKTÜRK, s. 40; CENTEL / ZAFER, s. 285; ÖZEN, s. 321.

141 DOSE, s. 350; BADER, vor § 48, kn. 11; SCHMITT, vor § 48, kn. 17; MAIER / PERCIC, vor § 48, kn. 14; OSTENDORF / BRUNING, $\S 16, \mathrm{kn} .7 ;$ ALSBERG / DALLMEYER, kn. 312.

142 BGH 25.09.1985 - 3 StR 335/85, NStZ 1986, 133 (MAIER / PERCIC, vor § 48, kn. 14; SCHMITT, vor § 48, kn. 17; IGNOR / BERTHEAU, vor $\S 48, k n .41$ ).

143 BGH 26.01.1996 - 2 ARs 441/95, StV 1996, 469 (BADER, vor § 48, kn. 11; OTTE, § 48, kn. 19; MAIER / PERCIC, vor § 48, kn. 14); BGH NStZ-RR 1997, 71 (ALSBERG / DALLMEYER, kn. 312); BGHSt 14, 265 (KINDHÄUSER / SCHUMANN, § 21, kn. 11; EISENBERG, kn. 1018; KÜHNE, kn. 806); IGNOR / BERTHEAU, vor § 48, kn. 41; ROGALL, vor § 48, kn. 51; GEPPERT, s. 87; HARTMANN / SCHMITT, kn. 291; GERCKE, vor § 48, kn. 9; von SCHLIEFFEN, vor § 48, kn. 29; PFEIFFER, vor § 48, kn. 2; HEGER / POHLREICH, kn. 366a; DOSE, s. 349, 350; ÖZTÜRK / TEZCAN / ERDEM / GEZER / SAY GILAR KIRIT / ALAN AKCAN / TÜTÜNCÜ / ÖZAYDIN / ALTINOK VILLEMIN / TOK, s. 302; KARAKEHYA, s. 224. 
nedeni gündeme gelecektir (CMK m 289/1-e) ${ }^{144}$. Nitekim Alman Ceza Muhakemesi Kanunu' nda yer alan hükümde açıkça hüküm vermekle görevli kişilerle savcılığın ve kalemde bir zabıt kâtibinin kesintisiz şekilde duruşmada hazır bulunmaları gerektiği ifade edilmiştir (§ 226I). Ceza Muhakemesi Kanunu' nda da "Duruşmada, hükme katılacak hâkimler ve Cumhuriyet savcısı ile zabıt kâtibinin ve Kanunun zorunlu müdafiliği kabul ettiği hâllerde müdafinin hazır bulunması şarttır." şeklinde benzer bir hükme ( $\mathrm{m}$ 188/1) yer verilmişse de düzenlemede "zorunlu müdafi" kapsama dâhil edilmiş, buna rağmen duruşmada hazır bulunma ifadesine "kesintisiz" ibaresi eklenmemiştir. Bununla birlikte hükmün "Müdafinin mazeretsiz olarak duruşmaya gelmemesi veya duruşmayı terk etmesi halinde duruşmaya devam edilebilir." şeklindeki ikinci cümlesinden hareketle müdafi dışındaki kişilerin duruşmada başka bir görev üstlenmeleri halinde duruşmaya devam edilemeyeceği sonucuna ulaşılabilir, böylelikle söz konusu ifadenin eksikliğinden kaynaklı ortaya çıkabilecek sorunun önüne geçilebilir. Kaldı ki aynı hükmün üçüncü fikrasında "Bir oturumda bitmeyecek davada, herhangi bir nedenle bulunamayacak üyenin yerine geçmek ve oya katılmak üzere yedek üye bulundurulabilir." hükmüne yer verilmek suretiyle bir kişinin aynı duruşmada iki görevi birden yapmasının mümkün olmadığı iyice pekiştirilmiştir. Bu noktada duruşma uzun sürmüş olabilir ki duruşma nın ilk oturumunda savcılık görevini yapan bir Cumhuriyet savcısının, bir sonraki oturumda yerine başka bir savcının görevlendirilmesi şartıyla olayla ilgili tanıklık görevini yerine getirmesi mümkün görülebilir. Tüm bunlar bir tarafa bırakıldığında bu konuda somut bir düzenleme bulunmasa bile aynı esnada bir kişinin hem tanıklık hem savcılık yapamayacağı, bu süjelerin hak ve yükümlülükleri dikkate alındığında da ifade edilebiliri ${ }^{145}$.

Bu konu kapsamında iki sorun üzerine tartışma yürütülmektedir. Birincisi, savcının kendi ifadesi öncesinde ve başka tanıkların ifadesi süresince Cumhuriyet savcısı olarak görev yapıp yapmayacağıdır. Öğretide hâkim görüş ${ }^{146}$, tanık olarak davet edilen savcının kendi ifadesi alınana kadar savcılık makamında önceki tanıkların ifadelerine katılmasına müsaade edilebileceği yönündedir. Bu görüşe göre her tanığın ayrı ayrı ve sonraki tanıklar yanında bulunmaksızın dinleneceğine dair hüküm (CMK m 52/1; AImCMK § 58 I) sadece düzenleyici bir hüküm olarak görülür ${ }^{147}$. Bu fikre karş1 şüpheyle yaklaşan diğer görüş ${ }^{148}$ ise bu şekilde tanıklık yapacak olan bir savcının tanıklığı öncesinde diğer tanıkların ifadesini almasına müsaade edilmemesi gerektiğini, nitekim bu savcının soruşturma aşama sındaki olay ve olgular üzerine de tanık olarak bilgi vermesi gerektiği hususunun hesaba katılması gerektiğini, keza duruşmada bulunarak diğer tanıkların ifadelerini dinleyen bir savcının kendi ifadesini, dinlemiş olduğu tanıkların ifadeleri üzerinden şekillendirip şekillendirmeyeceği hususunda tam olarak karar verilemeyeceğini belirtmektedir. Kanaatimiz, bu görüşün daha makul olduğu ve kanuni düzenlemelerle daha uyumlu olduğu yönündedir. Şayet bir savcının daha en baştan tanıklık yapacağı belli ise artık savcılık değil, tanıklık sıfatı ön plana çıkar ve kendisi bakımından bu kanuni düzenleme ler uygulama alanı bulur. Bununla birlikte soruşturma aşamasında şüphelinin beyanının alınmasına katılmış olan savcının, bu işlemle ilgili olarak kovuşturma evresinde tanıklığına ihtiyaç duyulması halinde artık bu andan itibaren tanıklık yönü ön plana çıkar ${ }^{149}$ ve her ne kadar bu ana kadar diğer tanıkların dinlenmesine katılmış olsa da bu aşamadan itibaren yukarıdaki bilgiler doğrultusunda aynı otur rumda olmamak kaydıyla tanık hakları ve yükümlülükleri kendisi üzerinde vuku bulur.

Bu noktada tartışılan ikinci sorun, Savcının tanıklık görevini yerine getirmesinden sonra yargılamanın devamına savcı sıfatıyla katılıp katılamayacağı ya da hangi kapsamda görev alabileceği, yargılamada kendi ifadelerini de değerlendirmesi gerekeceğinden objektifliğini sağlayıp sağlayamayacağıdır ki bu

CENTEL / ZAFER, s. 285; KARAKEHYA, s. 225

DOSE, S. 351.

146 BGHSt 21, 85 (KINDHÄUSER / SCHUMANN, § 21, kn. 10); ALSBERG / DALLMEYER, kn. 312; SCHMITT, § 243, kn. 8; SCHNEIDER, Hartmut: in Karlsruher Kommentar Strafprozessordnung, 8. Auflage, C.H.Beck, München, 2019, § 243, kn. 15.

147 SCHMITT, § 58, kn. 15; EISENBERG, kn. 1017; ALSBERG / DALLMEYER, kn. 312.

148 IGNOR / BERTHEAU, vor $\S 48, \mathrm{kn} .41$.

149 CENTEL / ZAFER, s. 285. 
konunun çok fazla gereği gibi tartışılmadığına işaret edilmiştir ${ }^{150}$. Bu çerçevede Alman Krallık Yüksek Mahkemesi, genel olarak savcının ifadesinden sonra iddia makamında bulunamayacağ mıyla kamusal iddia makamının uyumunun kanuna aykırı olmasa bile yapısal olarak birbirine uygun olmadığı görüşünden hareket etmiştir ${ }^{151}$. Alman öğretisinde günümüzde halen bu görüşte olan yazarlar ${ }^{152}$ bulunmakta olup bu düşünce sahipleri, tanıklık ifadesinin içeriğiyle ilgilenmemekte, yargılamada bir savcının tanıklık yapması gerekirse tanık olarak ifade vermesinin ardından genel olarak artık bu yargıla mayla ilgili olarak savcıllk görevinden söz edilemeyeceğini belirtmektedirler. Türk öğretisinde ${ }^{153}$ de yaygın şekilde bu görüşün kabul edildiği belirtilebilir. Hatta Şahin / Göktürk, hâkimin reddine dair hükmün savcı bakımından da kabul edilmesinin uygun olacağını vurgulamışlardır ${ }^{154}$.

Bununla birlikte Alman Federal Yüksek Mahkemesi, başlangıçta kararlarında herhangi bir sınırlama getirmeksizin Krallık Yüksek Mahkemesinin kararlarına dayanmışsa da ${ }^{155}$ sonrasında uygulamada bilhassa da kapsamı oldukça geniş olan yargılamalarda savcının rastgele değiştirilebilir olarak görülmesinin ortaya çıkardığı zorluklar nedeniyle ${ }^{156}$ anlayışında değişikliğge giderek belirli koşullar altında savcının görev alma sında bir engel olmayabileceği sonucuna ulaşmıştır. Bu çerçevede günümüz Alman mahkeme kararları$n ı n^{157}$ da dâhil olduğu Alman öğretisindeki diğer görüsş ${ }^{158}$, kural olarak savanın yargılamaya savcı olarak katılamayacağını, ancak bunun cevabının tanıklık ifadelerinin kapsamına bağlı olduğunu kabul etmektedir. Buna göre savcının tanıklık ifadesiyle devamında duruşmaya katılması arasında ayrılamaz nitelikte bir bağlantı söz konusu ise ${ }^{159}$, söz gelimi savcı yargılama konusu olan "fiilin ispatına ilişkin sorular üzerine" ifade verirse başka bir savcının bu ifadeyi mutlaka değerlendirmesi gerekeceğinden gerekli tarafsızlık ve objektifliğin tehlikeye düşürülmemesi adına savcının bu yargılamada artık göreve devam etmemesi gerekir (CMK m 160/2; AlmCMK § 160 II) ${ }^{160}$. Buna karşılık tanıklık ifadelerinin, sadece önemsiz yan sorulara ilişkin olması ve esas fiilin ispatından ayrılabilir yapıda olması halinde savcının bu davada görevine devam edebileceği yönünde bir istisnanın mümkün olduğu kabul edilmektedir ${ }^{161}$. Yine örneğin savcının ifadesi, sanıklardan yalnızca birinin işlediği fiil üzerine ise diğer sanıklar bakımından iddianame düzenlemesine engel bir durumun varlığından söz edilemeyeceği belirtilmektedir ${ }^{162}$. Alman mahkeme kararlarındaki bu görüş değişikliğinin temel nedeni, bilhassa geniş kapsamlı davalarda savcının ikinci bir konuda tanık olarak

150 GEPPERT, s. 87.

151 RGSt 29, 236 (ALSBERG / DALLMEYER, kn. 313; IGNOR / BERTHEAU, vor § 48, kn. 42; MOASBACHER, s. 132; DOSE, s. 351).

152 HANACK, Ernst-Walter: “Die Rechtsprechung des Bundesgerichtshofs zum Strafverfahrensrecht”, Juristenzeitung (JZ), 1971, s. 91.

153 FEYZIOĞLU, s. 56, 59; ÜNVER / HAKERİ, s. 256; SAHİ / GÖKTÜRK, s. 40; GÖKCEN / BALCI / ALSAHİN / ÇAKIR, s. 286; ÖZBEK / DOĞAN / BACAKSIZ, s. 587; ÖZEN, s. 321; YURTCAN, s. 213. Aksi görüş için bkz. KARAKEHYA, s. 224.

154 ŞAHIN / GÖKTÜRK, s. 40.

155 IGNOR / BERTHEAU, vor § 48, kn. 42. Nitekim BGH v. 07.06.1956-3 StR 148/56 kararında yargılamada duruşmada görev yapan hâkimin aynı olaya dair tanıklık yapması halinde reddedilmesine dair bir hüküm bulunmasına karşılık aynı durumun savcı bakımından geçerli olmadığı, böyle bir durumda savcının reddedilmeyeceği, bununla birlikte tanıklık yaptıktan sonra savcının aynı olaya dair yeniden görev üstlenmesinin hâkim görüşe göre mahkeme kararlarına göre savcının konumuyla uyumlu olmadığı, savcının kendi ifadesini çok nadir hallerde değerlendirmek zorunda kalmayacağı, bu bakımdan aynı olayla ilgili olarak tanıklık yapan savcının görevine devam etmemesi gerektiği ifadelerine yer verilmiştir. Kararın özeti için bkz. DALLINGER, Wilhelm: "Aus der Rechtsprechung des Bundesge richtshofes in Strafsachen", Monatsschrift für Deutsches Recht (MDR), 1957, s. 16; DOSE, s. 352.

156 ALSBERG / DALLMEYER, kn. 314.

157 OLG Düsseldorf StV 1991, 59 (BADER, vor § 48, kn. 11); BGH JR 2019, 160 (BEULKE / SWOBODA, kn. 288); BGHSt 21, 85 (KÜHNE, kn. 806; von SCHLIEFFEN, vor § 48, kn. 29); BGH NSt 1989, 583 (PFEIFFER, vor § 48, kn. 2); BGH NStZ 2008, 353 (MOASBACHER, s. 132).

158 BEULKE / SWOBODA, kn. 288; ROXIN / SCHUNEMANN, § 26, kn. 7; KINDHÄUSER / SCHUMANN, § 21, kn. 12; SCHMITT, vor $\S 48$, kn. 17; GERCKE, vor $\$ 48$, kn. 9; MOASBACHER, s. 132; MAIER / PERCIC, vor $\S 48, k n$. 14; BADER, vor $\S 48, k n .11$; OTTE, § 48, kn. 19; GEPPERT, s. 87; OSTENDORF, kn. 298; HEGER / POHLREICH, kn. 366a; DOSE, s. 353.

159 BGH 5 StR 529/75 (BADER, vor § 48, kn. 11); BGH NStZ 18, 482 (SCHMITT, vor § 48, kn. 17); BGHSt 21, 89 (GERCKE, vor $\S 48$, kn. 9; IGNOR / BERTHEAU, vor § 48, kn. 42); GEPPERT, s. 87.

160 BGH NStZ 1983, 135 (BADER, vor § 48, kn. 11); BGH NStZ 2007, 419 (SCHMITT, vor § 48, kn. 17); GEPPERT, s. 87; OSTENDORF / BRUNING, § 16, kn. 7.

161 BGHSt 14, 265 (KINDHÄUSER / SCHUMANN, § 21, kn. 12; SCHMITT, vor § 48, kn. 17; JOECKS, vor § 48, kn. 10); BGH NJW 1996, 2239 (JOECKS, vor § 48, kn. 10); BGH NStZ-RR 2001, 107 (von SCHLIEFFEN, vor § 48, kn. 29; ALSBERG / DALLMEYER, kn. 315); DOSE, S. 350.

162 BGH 21, 85, 89 (BADER, vor § 48, kn. 11; SCHMITT, vor § 48, kn. 17; JOECKS, vor § 48, kn. 10); ROXIN / SCHUNEMANN, § 26, kn. 7. 
ifadesinin alınması sağlanarak duruşmada savcı olarak görev yapmasının önüne geçilmesi ve bir başka savcının görevlendirilmesinin sağlanmasının yargılamanın sürdürülmesi açısından arzu edilmeyen ve kaçınılmaz zorlukları beraberinde getirmesidi $r^{163}$.

Tümbu bilgiler çerçevesinde savcının kendisinin suçtan zarar görmüş olması halinde artık fiilin ispatına ilişkin beyanlarda bulunacağından ve kendi ifadelerini de esasa matuf şekilde değerlendirmesi gereke ceğinden bu olayla ilgili olarak savcılık görevinde bulunmaması gerektiği sonucuna ulaşılabilir. Ancak yine de kanaatimize göre hâkimde olduğu gibi savcının da tarafsızlığını şüpheye düşüren bu tür durumlarda muhakemeden çekinmesi ve reddine ilişkin bir kanuni düzenleme yapılmasına yönelik ihtiyacın bulunduğu yönündeki görüş ${ }^{164}$ oldukça makul görünmektedir. Aksi takdirde bu derece önemli bir konu, birçok farkl1 görüşün ortaya çıkmasına neden olacak şekilde bir belirsizliğe mahkûm edilmiş olacaktır.

\section{Müdafi}

Alman Ceza Muhakemesi Kanunu'nun 53'üncü paragrafının birinci fikrasında meslek sebebiyle tanıklıktan çekinebilecek kişiler arasında avukatların, patent avukatının, noterlerin ve baroların diğer üyelerinin de sayılmış olması, bununla birlikte müdafinin görevinden yasaklanmasına ilişkin düzenleme (§ 138a) kapsamında tanıklık yapmanın müdafilik görevinin sonlanma nedenlerinden biri olarak öngörülmemiş olması nedeniyle Alman öğretisinde müdafinin, görevini bırakmadan aynı olaya dair tanık olabileceği görüşünden hareket edilmektedir ${ }^{165}$. Ceza Muhakemesi Kanunu'ndaki tanıklığa ve müdafiliğe ilişkin düzenlemeler göz önünde bulundurulduğunda Türk hukukunda da pekâlâ benzer bir sonuca ulaşılabilir ${ }^{166}$. Nitekim Ceza Muhakemesi Kanunu'nun 46'ncı maddesinin birinci fikrasının (a) bendinde avukatlar veya stajyerleri veya yardımcılarının, bu sıfatları dolayısıyla veya yüklendikleri yarg1 görevi sebebiyle öğrendikleri bilgiler nedeniyle tanıklıktan çekinebilecekleri düzenlenmiştir. Yine Ceza Muhakemesi Kanunu'nun müdafinin görevinden yasaklanmasını hüküm altına alan 151'inci maddesinde tanıklık yapma, yasaklılık hallerinden biri olarak gösterilmemiştir. Ayrıca çok daha önemlisi, Alman öğretisindeki hâkim görüşs ${ }^{167}$ tarafından tüm bu düzenlemelerden hareketle mahkemenin tanıklık yapan müdafinin tanıklıktan sonra müdafilik görevini sonlandırma yetkisine sahip olmadığı yönündeki anlayışı da Türk hukuku bakımından kabul edilebilir.

$\mathrm{Bu}$ çerçevede ilk olarak tanık olarak ifade vermiş olan müdafinin, devam eden duruşmalara müdafi sıfatıyla katılmasına müsaade edilip edilmeyeceği ve ikinci olarak tanıklık yapacak olan müdafinin, ta nıklık ifadesi öncesinde diğer tanıkların dinlenmesi esnasında duruşma salonunu terk etmesinin gerekip gerekmediği soruları üzerine bir tartışma ortaya çıkmaktadır. Kanuni düzenlemelerde en azından müdafiler özelinde bu konuda bir açıklık bulunmadığından Alman Krallık Yüksek Mahkemesi, müdafinin ceza muhakemesindeki rolünü ve fonksiyonunu di kkate alarak tanıklığın yükümlülükleriyle müdafinin konumunun uyuşmadığı, tanıklık ifadelerinin de dâhil olduğu ispat araçlarıyla gerçeğe ulaşmaya yönelik menfaatin ve buna bağlı olarak başka bir kişinin ifadeleriyle ikamesi mümkün olmayan müdafinin tanıklık ifadesinin, özgür şekilde müdafi seçme özgürlüğü ile müdafinin hakları karşısında üstün olduğu düşüncesinden hareketlemüdafinin tanıklık yapması ve görevine devam etmemesi yönünde bir yaklaşım sergilemiş, tanıklık yaptıktan sonra müdafinin görevine devam etmesi halinde çok fazla düzene uygun bir savunmanın mevcut sayılamayacağı, böyle bir durumda söz konusu müdafinin savunma yapmasının

163 BGH NStZ 1989, 583 (BADER, vor § 48, kn. 11).

164 MOASBACHER, s. 132; CENTEL, s. 35; CENTEL / ZAFER, s. 286; ŞAHİN / GÖKTÜRK, s. 40.

165 BGH 19.05.1953 - 2 StR 116/53, NJW 1953, 1600 (MAIER / PERCIC, vor § 48, kn. 23; EISENBERG, kn. 1014); BGH StV 1984, 499 (IGNOR / BERTHEAU, vor § 48, kn. 45; KINDHÄUSER / SCHUMANN, § 21, kn. 13); BGH NStZ 1985, 514 (BEULKE / SWOBODA, kn. 289); SCHMITT, vor § 48, kn. 18; KÜHNE, kn. 809; BADER, vor § 48, kn. 12; ROGALL, § 48, kn. 61, 65; EISENBERG, kn. 1016; OTTE, § 48, kn. 20; GEPPERT, s. 88; OSTENDORF / BRUNING, § 16, kn. 8.

166 ÖZTÜRK / TEZCAN / ERDEM / GEZER / SAYGILAR KIRIT / ALAN AKCAN / TÜTÜNCÜ / ÖZAYDIN / ALTINOK VILLEMIN / TOK, s. 302; FEYZIOĞLU, s. 42; SAHIN / GÖKTÜRK, s. 40.

167 SENGE, Lothar: Karlsruher Kommentar zur Strafprozessordnung mit GVG, EGGVG und EMRK, 8. Auflage, C.H.Beck, München, 2019, vor $\S 48$, kn. 12; SCHMITT, vor § 48, kn. 18; IGNOR / BERTHEAU, vor § 48, kn. 45; DAHS, s. 1385; ROXIN / SCHUNEMANN, § 26, kn. 9; OSTENDORF / BRUNING, § 16, kn. 8. 
engel lenmesinin bir yargılama hatası olarak nitelendirilemeyeceği sonucuna ulaşmışıır ${ }^{168}$. Bununla birlikte müdafinin tanıklık ifadesi önemsiz ise sadece yan konulara değinen bir öneme sahip ve esas duruşmadan ayrı şekilde çözümlenebilir durumda ise müdafinin tanıklık yapmasının mümkün olduğunu kabul eden Krallık Yüksek Mahkemesi, müdafinin soruşturma aşamasında ifade vermiş olması halinde müda filik görevini üstlenebileceğini belirtmiş ${ }^{169}$, dolayısıyla tanıklık yapan avukatın istisnaen müdafilik yapabileceği yönünde bir kural ortaya koymuştur. Krallık mahkemesi, ilerleyen süreç içerisinde yaklaşımını biraz yumuşatmış ve bu kuralı tersine çevirmiş, müdafinin tanıklık ifadesinden sonra savunmaya devam etmesini sıkıntılı hale getirecek türden bir öneme sahip olması halinde müdafinin istisnaen görevden alınması konusunda mahkemenin yetkili olduğu görüşünü benimsemiştir ${ }^{170}$. Alman Anayasa Mahkemesi, çok daha katı bir yaklaşım sergilemiş, mahkemenin tanık müdafinin görevine son verme yetkisini ve tanıklık yükümlülüğünün müdafinin savunma hakkı karşısındaki önceliğini reddetmiștir ${ }^{171}$. Buna uygun şekilde Alman Federal Yüksek Mahkemesi, tanıklık rolüyle müdafilik rolünün kural olarak birbiriyle uyumlu olduğu, müdafinin sadece istisnaen -zorunlu müdafilik durumunda görevden el çektirilmesinin gerekli ve mümkün olduğu görüşünden hareket etmiştir ${ }^{172}$.

Nihayetinde günümüzde müdafilik sıfatının sona ermesi için kanunda sayılan nedenler arasında tanıklık yapmış olma (AlmCMK $\S \S 138 \mathrm{a}, 138 \mathrm{~b}$ ) yer almadığından gerek Alman mahkeme kararlarında ${ }^{173}$ gerekse Alman öğretisinde ${ }^{174}$ benimsenen görüşe göre müdafinin tanık olarak ifadesinin alınmasından sonra da müdafilik görevine devam etmesi mümkün görülmekte, zorunlu müdafilik durumu söz konusu olmadığı sürece müdafinin tanıklık ifadesi süresince dahi müdafilik görevini yerine getirmesine müsaade edi Imekte, mahkemenin müdafinin görevine son verme yetkisi kabul edilmemektedir. Her ne kadar Türk öğretisinde hâkim görüş tarafından ${ }^{175}$ avukatın lehe ya da aleyhe ayrım yapılmaksızın tanıklık yaptığı olayla ilgili müdafilik görevini üstlenemeyeceği ifade edilmekte ve esasen Alman Krallık Yüksek Mahkemesi’nin benimsediği görüşten hareket edilmekteyse de bu konudaki kanaatimiz, daha evvel belirttiğimiz üzere Ceza Muhakemesi Kanunu'ndaki düzenlemelerin (CMK m 46/1-a; m 151), Alman öğretisinde ve mahkeme kararlarında günümüzde kabul gören anlayışın Türk hukuku bakımından da benim senmesine uygun olduğu ve hatta bunu gerekli kıldığı yönündedir ${ }^{176}$. Bununla birlikte yalnızca somut olayda bir zorunlu müdafilik görevi söz konusu ise bu müdafin tanık olarak ifadesinin alınması süresince söz konusu sanığa mutlaka başka bir müdafi görevlendirilmelidir. Zira bir avukat, tanık olarak müdafinin hak ve yükümlülüklerini gözetemeyeceğinden aynı kişinin, aynı anda hem müdafilik hem de tanıklık görevini üstlenmesinden söz edilemez ${ }^{177}$. Aksi durumda duruşmada bulunması gereken kişinin yokluğundan bahisle hukuka kesin aykırılık halinden (CMK m 289/1-e) bahsedilebilir ${ }^{178}$.

168 RGSt 24, 104 (ROGALL, § 48, kn. 63; IGNOR / BERTHEAU, vor § 48, kn. 48).

169 RGSt 24, 107, 108 (ROGALL, § 48, kn. 63).

170 RGSt 55, 219 (IGNOR / BERTHEAU, vor § 48, kn. 48).

171 BVerfGE 16, 217, 219 (PFEIFFER, vor $\S 48$, kn. 2; ROGALL, vor $\S 48, k n .64$ ).

172 BGH NJW 1953, 1601 (IGNOR / BERTHEAU, vor § 48, kn. 48).

173 BVerfG 11.06.1963 - 1 BVR 156/63, BVerfGE 16, 214 =NJW 1983, 1771 (MAIER / PERCIC, vor § 48, kn. 23); BGH NJW 1964, 404 (IGNOR / BERTHEAU, vor § 48, kn. 48).

174 KINDHÄUSER / SCHUMANN, § 21, kn. 15; HARTMANN / SCHMITT, kn. 293; IGNOR / BERTHEAU, vor § 48, kn. 47; MAIER / PERCIC, vor § 48, kn. 23; SCHMITT, kn. 18; GERCKE, vor § 48, kn. 10; BECKER, Jögr-Peter: in Löwe-Rosenberg Die Strafprozeßordnung und das Gerichtsverfassungsgesetz Großkommentar, Band 6, 27. Auflage, De Gruyter, Berlin/Boston, 2020, § 243, kn. 23; SCHNEIDER, § 243, kn. 15; OTTE, § 48, kn. 20; PFEIFFER, vor § 48, kn. 2.

175 FEYZİĞLU, s. 54, 55; YURTCAN, s. 214. Hatta Şahin / Göktürk, hâkimin reddine ilișkin açıkça düzenlenen hükmün müdafi bakımından da kabul edilmesinin uygun olacağını belirtmektedir (ŞAHİN / GÖKTÜRK, s. 40). Yine Gökcen / Balcı / Alşahin / Çakır da avukatların da savcı ve hâkim gibi yargı görevi gören kişiler olduğunu, suça ilişkin bilgiye sahipseler sadece tanıklık yapıp müdafilik görevini üstlenmemeleri gerektiğini ifade etmișler, benzer bir görüs ortaya koymuşlardır (GÖKCEN / BALCI / ALŞAHIN / ÇAKIR, s. 286). Özen, avukatın müdafilik yaparsa tanıklık yapamayacağını, tanıklık yaparsa müdafilik yapamayacağını, avukatın olayın tek tanığı ise bu defa tanıklık yapmak zorunda kalacağını ifade etmiştir (ÖZEN, s. 321, 322). Tüm bu görüşlere karşılık Karakehya, müdafinin tanıklık yapmasına rağmen görevine devam etmesinde bir sakınca bulunmadığını belirtmiştir (KARAKEHYA, s. 225)

176 CENTEL / ZAFER, s. 286; ÜNVER / HAKERİ, s. 256.

177 RGSt 54, 175 (ROGALL, § 48, kn. 61); BGH NJW 1953, 1601 (ROGALL, § 48, kn. 61; IGNOR / BERTHEAU, vor § 48, kn. 47; BADER, vor 48 kn. 12; EISENBERG, kn. 1015); BGH 26.06.1985 - 3 StR 145/85, NJW 1986, 78 (OTTE, § 48, kn. 20; MAIER / PERCIC, vor § 48, kn. 23); BGH StV 1996, 469 (KINDHÄUSER / SCHUMANN, § 21, kn. 14; HARTMANN / SCHMITT, kn. 293; JO- 
Keza müdafinin tanıklık ifadesinin müvekkilin lehine olabileceği gibi aleyhine de olabileceği yönündeki gerçek karşısında müdafi, müvekkilini suçlayıcı ifadede bulunup kendi ifadesini değerlendirmesinin özel önem arz ettiği bir durumda her ne kadar Alman öğretisinde müvekkilin kendisi müdafiyi görevden azletmediği ya da müdafinin kendisi görevden çekinmediği sürece müdafilik görevinin sırf al eyhe tanıklık ifadesi nedeniyle sona ermeyeceği, bu türden rol karmaşasının olduğu durumlarda bile kanunda müdafilik görevinin sona ermesi gerekçeleri arasında bu durum yer almadığından müdafinin görevine devam edip etmeyeceğine mahkemenin değil, ancak müdafinin kendisi ya da müvekkili karar verebileceği görüşü ileri sürülmüssse $\mathrm{de}^{179}$ kanaatimize göre artık avukatın müdafilik görevini üstlenmesi ya da sürdürmesinin müdafiliğin varlık sebebine aykırı olduğundan, bu durumun müvekkilin adil yargılama hakkının ihlali sonucunu beraberinde getirebileceğinden hareket edilmesi gerekir ${ }^{180}$. Dolayısıyla müdafinin aleyhe tanıklığı durumunda müvekkil azletmese ve müdafi kendisi görevden çekinme se bile mahkeme tarafından görevinden azledilebilmelidir.

Tanıklık yapacak olan müdafinin tanıklık ifadesi öncesinde duruşma salonunu terk etmesinin gerekip gerekmediği sorusu bakımından ise hâkim görüşe göre müdafinin duruşmada hazır bulunma hakkı, tanıkların bireysel olarak ve daha sonra dinlenecek tanıkların yokluğunda dinlenmeleri şeklindeki usûlden daha önemli addedilmekte ve müdafinin tanık olarak ifadesinin alınmasından önce diğer tanıklar gibi duruşma salonunda bulunmaması yönünde bir gerekliliğe ihtiyaç duyulmamaktadır ${ }^{181}$. Bununla birlikte tanıkların ayrı ayrı ve sonraki tanıklar yanında bulunmaksızın dinleneceğine dair hükmün (CMK m 52/1; AlmCMK § 58 fikra 1) ihlal edilmesi ihtimalinden sakınmak adına mahkemenin, tanık müdafiyi önceki bir zamanda dinleyebileceği önerisinde bulunulmaktadır ${ }^{182}$. Tüm bu açıklamalardan sonra kısaca müdafinin tanıklık ifadesinden önce ya da sonra duruşmalara katılmasına ve savunma yapmasına müsaade edilmesi gerektiği, müdafinin mahkeme salonunda kalarak gerektiğinde diğer tanıklarla yüzleştirilebilmesinin de mümkün olduğu belirtilmelidir ${ }^{183}$.

$\mathrm{Bu}$ noktada yanıtlanması gereken son husus, müdafinin müvekkiliyle mesleki ilişkisi nedeniyle edindiği bilgilerin tanıklık ifadesinin konusu olup olamayacağı, buna ne ölçüde müsaade edilebileceğidir. Esasında bir müdafi, müvekkilinin bilgilerini açıklayamaz, bu konuda tanıklık yapamaz. Bu husus, 1136 sayılı Avukatlık Kanunu'nun 36'ncı maddesinde açıkça, “Avukatların, kendilerine tevdi edilen veya gerek avukatlı görevi gerekse Türkiye Barolar Birliği ve barolar organlarındaki görevleri dolaylslyla ögrendikleri hususları açı̆̆a vurmaları yasaktır." şeklindeki ifadelerle ortaya konmuştur. Aksi takdirde özel hayatın gizliliğini ihlal suçunun (Türk Ceza Kanunu m 134) görevin verdiği yetkinin kötüye kullanılmak suretiyle işlenmesinden (Türk Ceza Kanunu m 137/1) bahsedilebilecektir ${ }^{184}$. Bununla birlikte müvekkili tarafindan sır saklama yükümlülügünden muaf tutulmuş olan (CMK m 46/1-a, 2; AlmCMK § 53 II 1; Alman Ceza Kanunu § 203 fikra 1 Nr. 3) müdafinin bu bilgileri açıklaması bakımından artık hukuki ya da cezai anlamda bir sorumluluktan söz edilemez ve bu bakımdan müdafi, mesleki niteliği gereği müvekkili tarafından kendisine verilen bilgiler hakkında tanıklık yapabilir ${ }^{185}$. Nitekim 1136 sayılı Avukatlık Kanunu'nun 36'nc1 maddesindeki hükmün devamı, “Avukatların birinci fikrada

ECKS, vor § 48, kn. 11); SCHMITT, vor § 48, kn. 18; GERCKE, vor § 48, kn. 10; BADER, vor § 48, kn. 12; KÜHNE, kn. 809; GEPPERT, s. 88; HEGER / POHLREICH, kn. 366a; ÖZTÜRK / TEZCAN / ERDEM / GEZER / SAY GILAR KIRIT / ALAN AKCAN / TÜTÜNCÜ / ÖZAYDIN / ALTINOK VILLEMİN / TOK, s. 302; CENTEL / ZAFER, s. 286; KARAKEHYA, s. 225.

180 BVerfGE 16, 217 (ROGALL, § 48, kn. 62); BVerfG NJW 1963, 1771 (GERCKE, vor § 48, kn. 10); IGNOR / BERTHEAU, vor § 48, kn. 45; BADER, vor § 48, kn. 12; EISENBERG, kn. 1014.

181 KINDHÄUSER / SCHUMANN, § 21, kn. 15; IGNOR / BERTHEAU, vor § 48, kn. 47; HARTMANN / SCHMITT, kn. 293; MAIER / PERCIC, vor § 48, kn. 23; BECKER, § 243, kn. 23; IGNOR / BERTHEAU, vor § 48, kn. 46, 47; SCHNEIDER, § 243, kn. 15; SCHMITT, vor $\S 48, \mathrm{kn} .18$.

182 IGNOR / BERTHEAU, vor § 48, kn. 47; MAIER / PERCIC, vor § 48, kn. 23.

183 IGNOR / BERTHEAU, vor § 48, kn. 47.

184 MAHMUTOĞLU, Fatih Selami / DURSUN, Selman: Türk Hukukunda Müdafiin Yasaklllık Halleri, Seçkin Yayıncılık, Ankara, 2004, s. 78.

185 BGH StV 2010, 287 (BEULKE / SWOBODA, kn. 289); IGNOR / BERTHEAU, vor § 48, kn. 45. 
yazılı hususlar hakkında tanıklık edebilmeleri, iş sahibinin muvafakatini almış olmalarına bağlıdır." şeklindedir. Şu hâlde müvekkil onay vermediği sürece müdafinin müvekkile ait bilgileri tanık sıfatıla vermek bir tarafa müdafi sıfatıyla dahi açıklaması uygun görülmemektedir ${ }^{186}$.

Bununla birlikte müvekkil, avukata verdiği bilgilerin açıklanmasına dair muvafakat göstermiş olsa bile avukat, tanıklık yapmaya zorlanamaz, yine de tanıklık yapmaktan çekinebilir. Nitekim 5271 sayılı Ceza Muhakemesi Kanunu'nda avukatlar dışındaki meslekler gereğince tanıklıktan çekinebilecek kişiler açısından ilgilinin rızasının varlığı halinde tanıklıktan çekinemeyeceklerine dair bir hükme yer verilmiş, böylelikle avukatların sır saklama yükümlülügünden muaf tutulmuş olmalarına rağmen tanıklık yapmaya zorlanamayacakları hüküm altına alınmıştır ${ }^{187}$. Keza benzer sonuca Avukatlık Kanunu' ndaki “...bu halde dahi avukat tanıklik etmekten çekinebilir. Çekinme hakkının kullanılması hukuki ve cezai sorumluluk doğurmaz...” yönündeki hükümden de ulaşılabilir. Görüldüğü üzere tanıklık yapmaktan kaçınan avukatın herhangi bir şekilde hukuki ya da cezai sorumluluğuna gidilemeyeceği de madde hükmüne sonradan (02.05.2001) eklenmiştir. Maddede yapılan bu değişiklik, CMUK m 48'teki “Müdafiler bu sıfatları... vaklf oldukları sirlar hakkında çekinebilirler. Ancak sır sahibi muvafakat ederse tanıkliktan çekinemezler." şeklindeki avukatı müvekkilin onayı halinde tanıklık yapmaya mecbur bırakan anlayışın ${ }^{188}$ değişmesinin bir sonucudur. Böylelikle avukatlar, diğer meslek sahiplerinden farklı bir yere konmuş, müvekkilin onayının tanıklık yapma yükümlülüğü değil, yalnızca tanıklık yapma hakkı tanıması kabul edilmiştir ${ }^{189}$. Buradan hareketle müvekkilin onayına rağmen avukatın kendisi, müvekkiline ait bilgileri açıkla mama yönünde bir takdi rde bul unabilir. Bunun en temel nedeni, mesleğe duyulan güvenin korunması ve çok önemlisi adaletin gereği gibi tesis edilmesidir. Zira avukata verdiği bilgilerin hiçbir surette açıklanmayacağına güvenen müvekkil, her türlü bilgiyi açıkça ve çekinmeden müdafiyle paylaşabilir, bu bilgilerin savunmaya hizmet etmesi amacıyla kullanılmasını temin edebilir ${ }^{100}$.

Alman Ceza Muhakemesi Kanunu'nda CMUK m 48 hükmüne benzer bir düzenleme bulunmas1 nedeniyle Alman hukukunda müvekkilin müdafiyi sır saklama yükümlülüğünden muaf tutmuş olması halinde artık müdafinin tanıklıktan çekinme imkânı bulunmamaktadır. Buna karşılık söz gelimi din adamları bakımından durum farklıdır ve sırrı veren kişi, din adamını sır saklama yükümlülüğünden muaf tutmuş olsa bile tanıklık kapsamında bu sırrı açıklayıp açıklamamak, tamamen din adamın takdirine bırakılmıştır. İşte Alman hukukunda avukatın müvekkili tarafından sır saklama yükümlülüğünden muaf tutulduğunda dahi tanıklıktan çekinebileceğine dair bir hüküm bulunmadığından Alman öğretisinde, sır saklama yükümlülüğünden muaf tutulmuş olan ilgili müdafinin müvekkille ilişkisinden kaynaklı olan her türlü bilgiyi söylemesinin gerekli olup olmadığ 1 sorusu tartışılmaktadır. Burada sırf müvekkilin müdafiyi sır saklama yükümlülüğünden muaf tuttuğu gerekçesiyle müdafinin müvekkiliyle ilgili her şeyi açıklamasının gerekli görülmesi, hem avukat-müvekkil ilişkisine dayalı tanıklıktan çekinme hakkını tamamen anlamsız hale getirir hem de avukat tıpkı diğer tanıklarda olduğu gibi genel kurallara tabi hale gelmiş olur ki bu açıdan böyle bir anlayış, hiçbir şekilde meslek gereği tanıklıktan çekinmeye ilişkin kanuni düzenlemelerle uyumlu olmayacaktır. Ignor / Bertheau, bu konuda din adamlarının sır saklama yükümlülüğünden muaf tutulmuş olmalarına rağmen ifade verip vermeyeceklerini ve hangi kapsamda ifade vereceklerini tamamen kendilerinin belirlemelerine imkân veren anla yışın benzer şekilde müdafiler bakımından da uygulanabileceğine işaret etmişlerdir ${ }^{191}$. Bu çerçevede iki hususa dikkat çekmek gerekir. Birincisi, öğretide müdafinin bizzat kendi araştırma ve kontakları

\footnotetext{
186 Bununla birlikte müdafinin müvekkilinden suçlu olmadığına dair bilgiler öğrenmesi ve fakat beraat edebilecek olmasına rağmen müvekkilin bu bilgilerin mahkemede açıklanmasına onay vermemesi halinde müvekkile rağmen müdafinin bu bilgileri duruşmada açıklayıp açıklayamayacağı konusundaki tartışmalar için bkz. MAHMUTOĞLU / DURSUN, s. 88.

187 “...sanıkların soruşturma aşamasında müdafilik görevini üstlenen avukat...' ’n, sanıklar tarafindan verilmiş bir muvafakat işlemi bulunmadığı ve tanıkliktan çekinme hakkı da hatırlatılmadığı halde tanık sıfattyla dinlenmesi ile beyanlarının hükme esas alınması..." Y. 17. CD., T., 03.05.2016, 13365/6633 (YAŞAR, C. I, s. 447).

188 MAHMUTOĞLU / DURSUN, s. 90.

189 MAHMUTOĞLU / DURSUN, s. 89.

190 MAHMUTOĞLU / DURSUN, s. 79, 80.

191 IGNOR / BERTHEAU, vor § 48, kn. 45.
} 
sayesinde müvekkili üzerine yaptığı işlemler çerçevesinde elde ettiği bilgileri müvekkilinin tasarrufur na bırakmasından söz edilemeyeceği görüşünün benimsenmiş olması ${ }^{192}$, ikincisi ise Alman Federal Yüksek Mahkemenin 5. Senatosunun görüşüne göre müdafine karşı belirli yönde bir beyanda buluna rak esasında muhakemedeki ifadesinin ağırlı̆ıını pekiştirme amacında olan bir sanığın bu savunma stratejisi karşısında müdafinin tanıklık ifadesinin ispata yönelik önemli bir etki göstermesi yönündeki anlayışın kabul edilmiyor olmasıdır ${ }^{193}$. Federal Mahkeme, savunma stratejisinin içeriği ve türü üzerindeki karar vermeye yönelik böylesi durumların kural olarak mahkeme tarafından tanıklık beyanından çıkartılıp savunma kapsamında addedilebileceği yönünde bir karara ulaşmışıır ${ }^{194}$. En nihayetinde tüm bu açıklamalardan sonra özellikle ifade edilmelidir ki Türk hukuku, bu konuda hukuki düzenleme bakımından Alman hukuku karşısında çok daha ileridedir. En baştan müdafinin tanıklık yapma konur sunda her türlü konuda kendi takdirine bırakılmış, Alman öğretisindeki söz konusu tartışmalara yer bırakılmamıştır. Öyle ki Alman öğretisindeki tartışma, müvekkili tarafindan sır saklama yükümlülügünden muaf tutulan ve tanıklık yapacak olan müdafinin bizzat kendi çabalarıyla müvekkil hakkında araştırıp bulduğu tespitlerin müvekkilin takdirine bırakılamayacağı, müvekkilinin bizzat kendisinin verdiği bilgiler üzerinden tanıklık ifadelerinin ise bu yöntemin bir savunma stratejisi olarak kullanılması ihtimali karşısında çok fazla güvenilir addedilmemesi gerektiği yönündeki bilgiler çerçevesinde anlamsız kalmaktadır. Bu açıdan Türk hukukunda müdafiye, müvekkilinin muvafakati halinde dahi tanıklıktan çekinmesi yönünde bir hakkın tanınmış olması gayet makul görünmektedir.

\section{D. Şüpheli ve Sanık}

Şüpheli ya da sanık, Anglo-Amerikan sisteminden farklı olarak ${ }^{195}$ kendisine karşı yürütülen soruşturma ve kovuşturma konusu olayla ilgili olarak taraf konumunda bulunduğundan tanık sifatiyla dinlenemez, tanıklıkla şüpheli ya da sanıklık konumu birbiriyle uyuşmaz ${ }^{196}$. Nitekim bir şüpheli ya da sanığın anayasal anlamda aleyhine delil vermeye zorlanamaması ve susma hakkının varlığı karşısında tanığın ifade verme ve gerçekleri söyleme yükümlülüğü bir çelişki oluşturacaktır ${ }^{197}$. Daha da önemlisi, mahkeme önünde "ifadeye karşı ifade" gibi tuhaf durumlar söz konusu olabilir ${ }^{198}$. Buradan hareketle esasa ilişkin açıklamalara hazır olduğunu bildiren bir şüphelinin ya da sanığın beyanları, kendisine karşı ispat aracı olarak kullanılamaz ${ }^{199}$. Dolayısıyla tanıkların yalan söylemesi halinde yalan tanıklık suçundan (TCK m 272 vd.) söz edilmekteyken sanıkların kimliklerine ilişkin bilgiler (KK m 40) dışında yalan beyanda bulunmaları durumunda herhangi bir cezalandırılabilirlikten söz edilmemektedir $r^{200}$.

192 BEULKE / SWOBODA, kn. 290; IGNOR / BERTHEAU, vor § 48, kn. 45.

193 BGH NStZ 2008, 115 (IGNOR / BERTHEAU, vor § 48, kn. 48).

194 BGH NStZ 2008, 115 (IGNOR / BERTHEAU, vor § 48, kn. 48).

195 KREY / HEINRICH, kn. 1215; EISENBERG, kn. 1005; ROGALL, vor § 48, kn. 40; ROXIN / SCHUNEMANN, § 26, kn. 4; HEGER / POHLREICH, kn. 366a; YASAR, C. I, s. 418; YURTCAN, s. 213; ÖZTÜRK / TEZCAN / ERDEM / GEZER / SAYGILAR KIRIT / ALAN AKCAN / TÜTÜNCÜ / ÖZAYDIN / ALTINOK VILLEMIN / TOK, s. 299; ÖZBEK / DOĞAN / BACAKSIZ, s. 586; ÖZEN, s. 322.

196 RGSt 52, 138 (KINDHÄUSER / SCHUMANN, § 21, kn. 16); BGH NJW 64, 1034 (SCHMITT, vor § 48, kn. 20); BGH v. 18.10.1956 4 StR 278/56, BGHSt 10, 8 (OTTE, § 48, kn. 21); IGNOR / BERTHEAU, vor § 48, kn. 8; HARTMANN / SCHMITT, kn. 249; ROXIN / SCHUNEMANN, § 26, kn. 3; PFEIFFER, vor § 48, kn. 3; KREY / HEINRICH, kn. 1212; BADER, vor § 48, kn. 7; ALSBERG / DALLMEYER, kn. 320; ROGALL, vor $\S 48, \mathrm{kn}$. 40; von SCHLIEFFEN, vor § 48, kn. 28; OSTENDORF / BRUNING, § 16, kn. 11; HEGER / POHLREICH, kn. 366a; GEPPERT, s. 82; HILLENKAMP, Thomas: “Der praktische Fall - Strafrecht: Das Aufnahmeritual und seine Folgen", Juristische Schulung (JuS), 2001, s. 166; FEYZIOĞLU, s. 45; YURTCAN, s. 213; ÖZBEK / DOĞAN / BACAKSIZ, s. 586; ÜNVER / HAKERİ, s. 255; CENTEL / ZAFER, s. 287; ÖZTÜRK / TEZCAN / ERDEM / GEZER / SAYGILAR KIRIT / ALAN AKCAN / TÜTÜNCÜ / ÖZAYDIN / ALTINOK VILLEMIN / TOK, s. 302; Yaşar, C. I, s. 418; ŞAHIN / GÖKTÜRK, s. 39; GÖKCEN / BALCI / ALŞAHIN / ÇAKIR, s. 286; ÖZEN, s. 322.

197 BGHSt 10, 8 (KINDHÄUSER / SCHUMANN, § 21, kn. 16; HARTMANN / SCHMITT, kn. 249); VOLK / ENGLÄNDER, § 20, kn. 2; ROGALL, vor § 48, kn. 40; EISENBERG, kn. 1005; HILLENKAMP, s. 166; GEPPERT, s. 82; CENTEL / ZAFER, s. 287; ŞAHIN / GÖKTÜRK, s. 39; ÖZBEK / DOĞAN / BACAKSIZ, s. 586; ÜNVER / HAKERİ, s. 255; ÖZEN, s. 322.

199 ROGALL, vor § 48, kn. 40.

200 GÖKCEN / BALCI / ALŞAHIN / ÇAKIR, s. 278; ÜNVER / HAKERİ, s. 255; ÖZTÜRK / TEZCAN / ERDEM / GEZER / SAYGILAR KIRIT / ALAN AKCAN / TÜTÜNCÜ / ÖZAYDIN / ALTINOK VILLEMIN / TOK, s. 302. 
Benzer durum, kural olarak suçun işlenişine katkı sağlayan bütün suç ortakları bakımından geçerlidir ki buna bağlı olarak istisnai durum haricinde suç ortaklarının birbirleri hakkında tanık olmalarına müsaade edilmez ${ }^{201}$. Ancak uygulamamızda da görüldüğü üzere suç ortakları tanık olarak dinlenebilmektedi $\mathrm{r}^{202} \mathrm{ki}$ bu çerçevede gerçekten istisnaen suç ortaklarının diğer suç ortakları bakımından tanıklık yapıp yapamayacakları ya da hangi ölçüde yapabilecekleri, esasında şüpheli ve sanık kavramlarının belirlenmesine ve bu kavramların zamansal anlamda sınırlarına bağlıdır ${ }^{203}$. İşte Alman öğretisinde bu konuda farklı görüşler ileri sürülmüştür. Bu görüşlerin tek tek ele alınmasından sonra bunların birbirinden ne ölçüde ayrıldığı, olay şeklindeki şu örnekler üzerinden daha makul şekilde anlaşılabilir:

Birinci ihtimalde yağma suçunu birlikte işleyen $\mathrm{X}$ ve $\mathrm{Y}$ isimli şahısların yakalanıp gözaltına alındığı ve tutuklanmak üzere hâkim huzuruna çıkartıldığı bir olayda $X$, itiraf niteliğinde kapsamlı ve güvenilir bir beyanda bulunurken Y, konuya ilişkin beyanda bulunmayı reddetmiş̧ir. İşte tam bu kapsamda tartışılan sorun, hâkimin Y'nin işlediği fiil üzerine X'i tanık olarak kabul edip tanık sıfatıyla ifadesini almasının mümkün olup olmadığıdır ${ }^{204}$. İkinci ihtimal olarak X ve Y'ye karşı yürütülen arama kararı sonucunda Y'nin yakalandığı, Almanya vatandaşı olan X'in ise Almanya'ya kaçtı̆̆ 1 ve Türkiye'ye iade edilmediğinden dolayı savcının sadece $\mathrm{Y}$ hakkında tutuklama talebinde bulunduğu olay kapsamında duruşmada X'in Y aleyhine tanıklık yapmasının kabul edilip edilemeyeceği ele alınabilir ${ }^{205}$. Üçüncü ihtimal olarak yağma suçunu birlikte işledikleri için $\mathrm{X}$ ve $\mathrm{Y}$ hakkında duruşma yapıldığı, ancak mahkemenin $X$ 'in yaşamsal tehlike arz eden nitelikte hasta olması nedeniyle X'e karşı yürütülen davayı Y'ye karşı olandan ayırmaya karar verdiği olayda sürekli yatağında yatar halde olan X'in, Y'ye karşı yürütülen yargılama ile ilgili olarak tanıklık yapmasına engel bir durum bulunmadığı takdirde tanıklık görevinde bulunup bulunamayacağ 1 irdelenmelidir ${ }^{206}$. Nihayet dördüncü ihtimal olarak $\mathrm{X}$ ve $\mathrm{Y}$ hakkında cinsel saldırı suçunu birlikte işledikleri için ikisiyle ilgili yapılan kovuşturmada $\mathrm{Y}$, esasa ilişkin ifadesinde fiili inkâr ederken X kapsamlı ve inandırıcı bir ifade vermiştir. Buradan mahkeme, X'e karşı olan yargılamayı bir kararla ayırmış ve devamında Y'nin fiile yönelik katkısıyla ilgili olarak X'e tanıklık görevi vermiş, tanıklık görevinin icrasından sonra bu ikisine karşı yürüttüğü yargılamaları birleştirmiştir ${ }^{207}$.

a) Alman mahkeme kararlarında ${ }^{208}$ ve Alman öğretisinde hâkim görüş ${ }^{209}$ tarafindan şekli anlamda şüpheli veya sanık kavramı savunulmuştur. Türk öğretisinde kısmen karşıllık bulduğu ${ }^{210}$ ifade edilebilecek olan bu görüşe göre suç ortakları bakımından ataç$^{211}$ etkisi gösteren yalnızca "yargılama ortakl1ğı" yönündeki şekli kriterdir ${ }^{212}$. Bu açıdan yargılamanın bağlı olması söz konusu ise bu defa bu kişilerin birlikte suç işlemiş mi olduklarının ya da şüphelisi ya da sanığı olmasalar bile bir fiilin işlenişi-

201 BGH 18.10.1956 - 4 StR 278/56, BGHSt 10, 8 (MAIER / PERCIC, vor § 48, kn. 24; BADER, vor § 48, kn. 7); KINDHÄUSER / SCHUMANN, § 21, kn. 17; HARTMANN / SCHMITT, kn. 249; ROXIN / SCHUNEMANN, § 26, kn. 5; SCHMITT, vor § 48, kn. 21; von SCHLIEFFEN, vor $\S 48$, kn. 28; OTTE, § 48, kn. 22; OSTENDORF / BRUNING, § 16, kn. 11; GÖKTÜRK, s. 374; İNCE TUNÇER, S. 83.

202 ÖZBEK / DOĞAN / BACAKSIZ, s. 586.

203 ROGALL, vor $\S 48, \mathrm{kn} .43$.

204 KREY / HEINRICH, kn. 1217.

205 KREY / HEINRICH, kn. 1222.

206 KREY / HEINRICH, kn. 1222

207 KREY / HEINRICH, kn. 1229

208 RGSt 46, 88 (KINDHÄUSER / SCHUMANN, § 21, kn. 18); BGHSt 10, 8 (SCHMITT, vor § 48, kn. 22); BGHSt 34, 44 (ROXIN / SCHUNEMANN, § 26, kn. 5); BGH NStZ 1984, 464 (KREY / HEINRICH, kn. 1220); BGH 3, 142 (PFEIFFER, vor § 48, kn. 3).

209 SCHMITT, vor § 48, kn. 21; ROGALL, vor § 48, kn. 43; BADER, vor § 48, kn. 7; von SCHLIEFFEN, vor § 48, kn. 28; OTTE, § 48, kn. 22; PFEIFFER, vor § 48, kn. 3; KREY / HEINRICH, kn. 1225.

210 KUNTER, s. 634. Buna göre Feyzioğlu'nun suç işlediği şüphesi bulunsa dahi kişiye suç isnadında bulunulmadığından bahisle şüpheli konumundaki kişinin tanık olarak dinlenebileceğini, bununla birlikte bu kişinin ifadesinin şüpheli olduğu dikkate alınarak değerlendirilmesi gerektiğini belirttiği (FEYZİĞGLU, s. 49) ifadelerinden hareketle şekli anlamda şüpheli ve sanık kavramından hareket ettiği sonucuna ulaşılabilir.

211 BADER, vor § 48, kn. 8; KINDHÄUSER / SCHUMANN, § 21, kn. 18; von SCHLIEFFEN, vor § 48, kn. 28; PFEIFFER, vor § 48, kn. 3; OSTENDORF / BRUNING, § 16, kn. 11.

212 BGH 23.04.1984 - 4 StR 781/83, NJW 1985, 76 (MAIER / PERCIC, vor § 48, kn. 25); OTTE, § 48, kn. 22. 
ne katkı mı sağladıklarının bir önemi olmaz ${ }^{213}$. Bu kişilerin yargılaması, her ne sebeple ol ursa olsun birbirine bağlı olduğu sürece (AImCMK $\S \S 2,3,237$ ) şüpheli veya sanıkların birbirleri hakkında tanıklık yapmalarından söz edilemez, bu şekilde bir tanıklık geçersiz kabul edilir ${ }^{214}$. Aynı muhakeme aşamasında ilgili kişinin ya tanık olduğu ya da şüpheli yahut sanık olduğundan hareket edilir ki bu anlamda bir kişi aynı muhakeme evresinde hem tanık hem şüpheli veya sanık olamaz ${ }^{215}$.

$\mathrm{Bu}$ görüşe göre birden fazla suç ortağına karşı ortak dava açılmamışsa ya da başka nedenlerle aynı duruşmada sanık olarak bulunmuyorlarsa ortak davanın varlığından bahsedilemeyeceğinden ${ }^{216}$ kovuşturma aşamasında bir suç ortağının suç ortağı olan sanık hakkında tanık olup olamayacağı, bu kişinin kendisine karşı da kovuşturma başlatılıp başlatılmadığına göre belirlenir. Kişinin kendisine karşı soruşturma başlatılmış olsa bile henüz kendisine karşı kovuşturma başlatılmış olma yan bir kişi, sanık konumundaki diğer kişiler bakımından tanıklık yapabilirr ${ }^{217}$, yeter ki kişinin kendisinin iştirak etmediği ya da kendisini ilgilendirmeyen bir fiil nedeniyle tanıklık yapması talep edilmiş olsun ${ }^{218}$. "Yargılama ortaklığı" yönündeki şekli kriter çerçevesinde bu yargılama ortaklığına son verildiğinde, yani söz gelimi sanığın kamu görevlisi olması nedeniyle yargılamanın ayrı yürütülmesine ya da sanığın beraat etmesine karar verildiğinde artık yargılama ortaklığından bahsedilemeyeceğinden bu kişinin bu andan itibaren diğer sanıklar hakkında tanıklık yapmasından söz edilebili $r^{219}$. Bu görüş kapsamında sanığın kendisi aleyhine etki etmeyecek olması ${ }^{220}$ ve ortak işlenen fiil olmadığ $1^{221}$ sürece sırf tanık olarak beyanına başvurabilmek amaciyla davanın hâkim tarafından geçici olarak ayrılması da mümkün görülmektedir ${ }^{222}$. Nitekim bu şekilde gerek Alman Krallık Yüksek Mahkemesi gerekse Federal Yüksek Mahkeme tarafından sırf suç ortaklarından birinin tanık olarak ifadesine başvurmak amacıyla yargılamanın sıklıkla ayrılması yönünde bir yönteme başvurulduğuna dikkat çekilmiştir ${ }^{223}$. Bu nedenle bu görüş, kasıtlı olarak rol değişiminin sağlanması bağlamında bir manipülasyon yapılarak rollerin dolanıldığı gerekçesiyle sorunlu görülmüş ve sert şekilde eleştirilmiştir ${ }^{224}$. İşte bu görüşe karşılık tepkisel olarak şekli-maddi şüpheli veya sanık anlayışı ve bilhassa da maddi anlamda şüpheli veya sanık anlayışı ortaya çıkmiştır 225 .

Illk ihtimal bakımından bu görüşe göre aynı muhakeme aşamasında eş zamanlı takip içerisinde yargılama ortaklığı esas alındığından ve olayda soruşturma aşamasında hâkim tarafından sanıkların ortak ifadeleri alındığından tanıklık kabul edilmeyecektir ${ }^{226}$. İkinci ve üçüncü ihtimallerde ise

213 BGH v. 15.08.1952 - 3 StR 267/52, BGHSt 3, 149 (OTTE, § 48, kn. 22).

214 BGHSt 27, 139 (BEULKE / SWOBODA, kn. 290); KREY / HEINRICH, kn. 1220; IGNOR / BERTHEAU, vor § 48, kn. 35; SCHMITT, vor $\S 48$, kn. 21; GERCKE, vor § 48, kn. 8; FEYZIOĞLU, s. 53.

215 ROGALL, vor $\$ 48, \mathrm{kn} .44$.

216 BGH NStZ 1984, 464 (KREY / HEINRICH, kn. 1220); IGNOR / BERTHEUA, vor § 48, kn. 36; SENGE, vor § 48, kn. 8.

217 BGH 18.10.1956 - 4 StR 278/56, BGHSt 10, 8 =NJW 1957, 230 (PRITTWITZ, Comelius: "Der Mitbeschuldigte- ein unverzichtbarer Belastungszeuge?", Neue Zeitschrift für Strafrecht (NStZ), 1981, s. 463; MAIER / PERCIC, vor § 48, kn. 25); ROGALL, vor § 48, kn. 39; ROXIN / SCHUNEMANN, § 26, kn. 5. Benzer şekilde bkz. FEYZIOĞLU, s. 51.

218 ROGALL, vor $\$ 48, \mathrm{kn} .44$.

219 BGH 23.04.1984 - 4 StR 781/83, NJW 1985, 76 (MAIER / PERCIC, vor § 48, kn. 26); von SCHLIEFFEN, vor § 48, kn. 28; PFEIFFER, vor $\S 48, \mathrm{kn} .3$.

220 BGH v. 25.04.1964 - 1 StR 13/64, NJW 1964, 1034 (OTTE, § 48, kn. 23); FEYZİŎLU, s. 53, 54.

221 BGH v. 17.01.1984 - 5 StR 970/83, StV 1984, 186 (OTTE, § 48, kn. 23).

222 RGSt 69, 390 (ROXIN / SCHUNEMANN, § 26, kn. 5); BGH v. 18.10.1956 - 4 StR 278/56, BGHSt 10, 8 (OTTE, § 48, kn. 23); BGH NJW 1964, 1934 (SCHMITT, vor § 48, kn. 22); JOECKS, vor § 48, kn. 11; von SCHLIEFFEN, vor § 48, kn. 28; PFEIFFER, vor 448 , kn. 3.

223 RG GA 36, 168; BGH NJW 1964, 1034 (PRITTWITZ, NStZ 1981, s. 464).

224 ROGALL, vor § 48, kn. 46; IGNOR / BERTHEAU, vor § 48, kn. 36; ROXIN / SCHUNEMANN, § 26, kn. 5; DUNNEBIER, Hanns: "Die Verbindung von Strafsachen nach §§ 2 bis 4, 13 StPO", Juristische Rundschau (JR), 1975, s. 3; GERCKE, vor § 48, kn. 8; KREY / HEINRICH, kn. 1230; GEPPERT, s. 85; PRITTWITZ, s. 464; LUDERSSEN, Klaus: “Rollenkonflikte im Verfahren: Zeuge oder Beschuldigte", wistra-Zeitschrift für Wirtschaft, Steuer, Strafrecht (wistra), 1983, 232.

225 ROGALL, vor § 48, kn. 46; PRITTWITZ, s. 464

226 KREY / HEINRICH, kn. 1221. 
$X$ 'in Y'ye karşı yapılan duruşmada tanık olarak ifade vermesi mümkün görülür ${ }^{227}$. Nitekim X ve $Y$, her ne kadar her iki olayda da şüpheli olsalar bile tanıklık rolünün reddedilmesi için gerekli olan yargılama ortaklığı bulunmamaktadır. Zira X, Y'ye karşı yapılan duruşmada ortak yargılanan kişi konumunda değildir. İkinci intimalde tutuklama talebi sadece $Y$ hakkında ileri sürülmüşken üçüncü olayda X'e karşı yargılamanın esastan ayrılmasıyla birlikte yargılama ortaklığı ortadan kaldırılmıştır ${ }^{228}$. Dördüncü ihtimalde davanın sırf diğer sanığın ifadesinin alınması için ayrılmasına uygun gözüyle bakılsa bile tanıklık ifadesinin kişinin kendisinin de suçlanmasına yol açmayacağı fiile ilişkin olmasına izin verilir. Dolayısıyla X ve Y'nin birlikte işledikleri suç nedeniyle dava ayrılsa bile bu kişilerden birinin diğerinin işlediği fiil hakkında tanıklığına başvurulamaz ${ }^{229}$.

b) Alman öğretisinde bir kısım görüş sahibi ${ }^{230}$, maddi anlamda şüpheli veya sanık anlayışından hareket etmekte, yargılamanın tekliği şeklindeki şekli kriteri önemsiz görmekte, her şüpheli ya da sa nığı yargılamadaki şekli konumu dikkate almadan "aynı fiile iştirak etmiş suç ortakları olarak aynı fiilin şüphelisi" şeklinde değerlendirmektedir. Yargılamanın ayrılması, şüpheye dair hiçbir şeyi değiştirmez ve dolayısıyla bu kişilerin şüpheli ya da sanık olmaları noktasında bir değişikliğe ne den olmaz. Şekli anlamdaki görüşte olduğu gibi yargılamada rol alan kişilerde yargılamanın ayrılması üzerinden yapılan kasıtlı rol değişimi, tamamen uygunsuz bir manipülasyon olarak görülür ve bu bakımdan suç ortakları, yargılamanın ayrılmasından sonra da hiçbir şekilde tanık sıfatıyla dinlenemez ${ }^{231}$. Hatta bu görüşte ortak yargılamada bir şüpheli ya da sanığın ifadesinin diğerinin aleyhine kullanılmasına izin verilmez, zira bu durumda suç ortaklarından biri esasa göre tanık konumuna getirilmiş olacaktır. Bu görüşün, Türk öğretisinde savunulduğu ifade edilebilir. Nitekim Şahin/Göktürk'e göre ileride suç şüphesi altında kalması muhtemel kişiler de tanık olarak dinlenememeli, dinlenmişlerse bile kişiler şüpheli ya da sanık olduğunda bu ifadeler soruşturma ya da kovuşturma aşamasında kullanılmamalıdır ${ }^{232}$. Keza Ünver / Hakeri'ye göre de suç işleyen kişilerin birbirleri aleyhine tanıklık yapmaya hiçbir şekilde zorlanamamaları gerekmektedir ${ }^{233}$.

Schmitt, bu görüşün oldukça katı olduğunu, nitekim tanık olarak ifade veren bir kişinin bir anda söz konusu yargılamanın şüphelisi haline gelebileceğini, yine tam tersi şüpheli olarak ifade veren kişinin hakkında kovuşturma başlatılmayabileceğini, bu öğreti çerçevesinde kabul edilen anlayışla birlikte bu tür durumlarda da tanıklığın kabul edilmeyeceğini ifade etmiş̧irir ${ }^{234}$. Ayrıca bu görüş, kovuşturma konusunu teşkil eden olayla suçlanan veya bu olaya iştirak ettikleri iddia edilen yahut suçluyu kayırma ya da suç eşyasının satın alınması, satılması veya temin edilmesi suçunu işlediği şüphesi altında bulur nan kişilerin yeminsiz dinlenmelerine yönelik Alman Ceza Muhakemesi Kanunu' nun § 60 Nr. 2 hükmü karşısında bu kimselerin her şekilde tanıklığının mümkün olabileceği gerekçesiyle eleştirilmektedir ${ }^{235}$. Bu bakımdan bu görüşün Türk hukukunda da kabulü, pek mümkün görünmemektedir. Nitekim Alman Ceza Muhakemesi Kanunu' ndaki bu hükme benzer bir hükmeCeza Muhakemesi Kanunu’nda da yer verilmiştir. Bu düzenlemeye göre mevcut olan soruşturma veya kovuşturma konusu suçlara iştirakten veya bu suçlar nedeniyle suçluyu kayırmaktan ya da suç delillerini yok etme, gizleme veya de ğiştirmekten şüpheli, sanık veya hükümlü olanların yeminsiz dinlenecekleri öngörülmüştür (CMK m

\footnotetext{
227 BGH St 10, 8, 11 (KREY / HEINRICH, kn. 1224); IGNOR / BERTHEAU, vor § 48, kn. 36; SENGE, vor § 48, kn. 8.

228 KREY / HEINRICH, kn. 1224.

229 KREY / HEINRICH, kn. 1230.

230 DUNNEBIER, s. 3, 4; KÜHNE, kn. 803; RENGIER, Rudolf: “Anmerkung: BGH, Urt. v. 4.11.1986 - 1 StR 498/86”, Der Strafverteidi$\operatorname{ger}(\mathrm{StV}), 1988,467$.

231 KÜHNE, kn. 803; RENGIER, s. 467; BEULKE / SWOBODA, kn. 290; ROXIN / SCHUNEMANN, § 26, kn. 5.

232 ŞAHIN / GÖKTÜRK, s. 39. Benzer yönde bkz. SOYASLAN, s. 458; İNCE TUNÇER, s. 86.

233 ÜNVER / HAKERİ, s. 257.

234 SCHMITT, vor $\S 48, \mathrm{kn} .21$.

235 ROXIN / SCHUNEMANN, § 26, kn. 5; MAIER / PERCIC, vor § 48, kn. 25; KREY / HEINRICH, kn. 1225; GEPPERT, s. 85.
} 
50) ${ }^{236}$. Nitekim bu düzenleme, Türk öğretisinde bazı yazarlar ${ }^{237}$ tarafindan eleştirilmekte, sanıkların birbirlerine karşı hiçbir şekilde tanıklık yapmaları uygun görülmemektedir.

Illk ihtimal bakımından bu görüş çerçevesinde her iki kişi de suçu ortak işleme nedeniyle şüpheli oldukları için evleviyetle birlikte sanık konumunda olacaklardır ve birbirleri hakkında tanıklık görevinde bulunamayacaklardır ${ }^{238}$. İkinci ve üçüncü ihtimalde de X'in tanıklığına müsaade edilmez. Zira X ve Y, birlikte şüphelidir ve bu durum X'in tanıklık yapmasına engel teşkil eder ${ }^{239}$. Bu görüş kapsamında zaten şekli sanık anlayışı sırf tanıklık ifadesi için yargılamanın ayrılmasını uygun görmesi nedeniyle eleştirildiğinden dördüncü ihtimaldeki durum hiçbir şekilde uygun görülmez.

c) Nihayet bizim de yakın durduğumuz şekli-maddi şüpheli veya sanık anlayışını esas alan görüşe $\mathrm{e}^{240}$ göre şekli sanık kavramını esas alan görüşteki gibi aynı şekilde "yargılanan fiil"den hareket edilir, ancak burada tek başına fiile yönelik şüphe esas alınmaz. Bu anlayışta şekli unsur, ilgili fiil nedeniyle gerçek anlamda yetkili makamlar tarafından ceza soruşturmasının başlatılmasına yönelik iradenin varlığı (şekli unsur), maddi unsur ise kişilerin yargılamadaki şekli rollerinden bağımsız olarak aynı fiil nedeniyle şüpheli olup olmadıklarına bakılmaksızın fiilin işlenişine katkı sağlamış olmalarıdır. Dolayısıyla şekli sanık anlayışından farklı olarak aynı fiil bakımından soruşturulan bir şüphelinin, sanık konumundaki suç ortağ hakkında tanıklık yapmasından söz edilemez. Zira her ikisi hakkında da aynı fiil nedeniyle soruşturma başlatılmıştır. Bu görüşe göre "aynı fiile ilişkin olmak" kaydıyla davanın ayrılmasından sonra da sanığın tanıklık beyanında bulunması söz konusu olamaz. Bununla birlikte bağlı yargılama içerisinde tanıklığa, yargılama konusu fiile dayalı olan ve fakat davadaki diğer kişinin ilgili olmayıp bilgi sahibi olması halinde müsaade edilebilir. Buna göre bir kişiye karşı birlikte yaralama suçunu işleyen iki kişinin yargılandığı bir dava da sanıklardan birine diğerinin yaralama dışında mağdura karşı işlediği hakaret suçu bağlamında bilgi sorulabilir ${ }^{241}$.

$\mathrm{Bu}$ görüş, haklı olarak şekli anlamda sanık anlayışı kapsamında sanıklardan birinin tanıklık yapmasını sağlamak amacıyla hâkime istediği zaman geçici olarak yargılamanın ayrılmasına karar verme yetkisi verilerek yargılamada ilgili kişinin haklarının yargılama organlarının keyfine bırakılmasına izin verilmemesi gerektiği anlayıșından hareketle șekli anlamda sanık anlayıșını daikna edici görmemekte ve bu anlayışın daraltılması gerektiği düşüncesinden hareket etmektedi ${ }^{242}$. Bağlantının bulunduğu bir yargılama içerisinde bir sanığın tanık sıfatıyla ifadesinin alınmasına, ancak "yargılama konusu fiile dayalı olarak yargılanmaması" şartıyla müsaade edilebilir. Ayrıca yargılama kendisine karşı tamamen sona erdirilmişse artık özel koruma değeri sona ermiş olacağından önceden sanık sıfatını haiz olmuş olsa bile bir kişi, tanık olarak dinlenebilir ${ }^{243}$. Bu noktada sanığın yargılamanın ayrılmasıyla sadece başka bir sanığı ilgilendiren konuda tanık olarak ifade vermesine müsaade edilebileceği şerhi düşülmektedir ${ }^{244}$. Hatta böyle bir durumda, artık kişinin tanıklığa ve hatta yemin etmeye zorlanması gündeme gelebilir, buna direnmesi halinde hakkında disiplin hapsi (CMK m 60) uygulamasına dahi başvurulabilirr ${ }^{245}$. Dolayısıyla yargılama ayrılmasına rağmen iştirak halinde işlenen fiiller bakımından sanığın tanıklık yapması, bu kişinin esasen kendi

\footnotetext{
236 CENTEL / ZAFER, s. 287; ÖZBEK / DOĞAN / BACAKSIZ, s. 586.

237 ÜNVER / HAKERİ, s. 257; ŞAHIN / GÖKTÜRK, s. 39.

238 KREY / HEINRICH, kn. 1221.

239 KREY / HEINRICH, kn. 1223.

240 BGH 23.04.1984 - 4 StR 781/83, NJW 1985, 76 (MAIER / PERCIC, vor § 48, kn. 25); IGNOR / BERTHEAU, vor § 48, kn. 36; BEULKE / SWOBODA, kn. 290; ROXIN / SCHUNEMANN, § 26, kn. 5; GEPPERT, s. 86; HILLENKAMP, s. 167; LUDERSSEN, s. 232; PRITTWITZ, S. 469.

241 KINDHÄUSER / SCHUMANN, § 21, kn. 20.

242 HILLENKAMP, s. 167; PRITTWITZ, s. 467, 468; BEULKE / SWOBODA, kn. 290; KREY / HEINRICH, kn. 1219.

243 BEULKE / SWOBODA, kn. 290.

244 BGH NJ W 1964, 1034 (BADER, vor § 48, kn. 9).

245 CENTEL / ZAFER, s. 287.
} 
yargılamasında tanıklık yapması olarak görüleceğinden ve bu, kendi al eyhine ifade vermeye zorlama anlamına geleceğinden buna izin verilemez ${ }^{246}$, bu kişi tanıklıktan çekinme hakkını kullanabilir, bu şekilde tanıklık yapmaya zorlanamaz ${ }^{247}$. Zira böyle bir durumda rol değişimi değil, izin ve rilmeyen şekilde rollerin dolanılması gündeme gelecektir ${ }^{248}$. Bundan daha da önemlisi hâkimin kendi takdiri kapsamında davaları ayırma ve birleştirmesi suretiyle süjeler üzerinde rol değişimine müsaade edilmekteyse de ${ }^{249}$ şekli sanık anlayışından farklı olarak yargılamanın sırf sanığın tanıklık yapabilmesi amacıyla geçici olarak ayrılmasına müsaade edilmez. Buna göre yalnızca sanığın ifadesinin alınması amacına yönelik olarak yargılamanın geçici şekilde ayrılması, takdir hakkının kötüye kullanılması olarak görülür ve buna izin verilmez ${ }^{250}$. Böyle bir durumda suç ortağının tanıklık yapmaya ve yemine zorlanması söz konusu olamaz, bu nedenle hakkında disiplin hapsi uygulamasına gidilemez ${ }^{251}$. Bu görüş kapsamında her ne kadar ceza muhakemesinde suç ortağ sui generis tanık olarak görülmese de ${ }^{252}$ Prittwitz' e göre ispat aracı olarak şüpheli ve sanıkların tanıklığı bakımından ceza muhakemesinde bir kanuni boşluk olup bu boşluğun doldurulması gerekmektedir ${ }^{253}$. Diğer bir deyişle bu tartışmaların sonlandırılması adına haklı olarak bu tespitlerin ka nuna bir şekilde yansıtılması, faydadan da öte bir ihtiyaç olarak kendini göstermektedir.

Bu açıdan ilk ihtimal bakımından bu görüşle birlikte aynı fiil nedeniyle yargılama ortaklığı içerisinde aynı fiil nedeniyle soruşturuldukları için şekli anlamda muhakemedeki rollerinden bağımsız olarak tanıklık yapmalarından söz edilemez ${ }^{254}$. Íkinci ve üçüncü ihtimal açısından X'in tanıklık yapmasına müsaade edilmez. Çünkü $X$ ve $Y^{\prime}$ ye karşı aynı fiil nedeniyle soruşturma yürütülmekte ve $X^{\prime}$ in şekli anlamda davada bir rolü bulunmaktadır. Bu görüşe göre ayırmadan sonra dahi $X$ 'in Y'ye karşı yapılan duruşmada tanık olmasından söz edilemez ${ }^{255}$. Dördüncü ihtimal rollerin dolanılması olarak görülür ve buna izin verilmez.

\section{E. Diğer Kişiler}

\section{Mağdur}

Alman Ceza Muhakemesi Kanunu'na göre katılanın tanık olarak dinlenecek olmasına rağmen katılma isteğinin kabul edilmesinden sonra duruşmada hazır bulunma hakkına sahip olduğu yönündeki düzenleme den (§ 397 I) hareketle katılanın tanıklık yapabilmesi ve hatta sonrasında duruşmalara katılması, katılanın sahip olduğu tüm hakları kullanabilmesi mümkün görülmektedir ${ }^{256}$. Buna karşıllk Alman öğretisinde hâkim şekilde şikâyetçi konumunda bulunan kişinin tanık olamayacağı görüşü kabul edilmektedir ${ }^{257}$.

Bununla birlikte Ceza Muhakemesi Kanunu'nun, "Mağdurun tanık olarak dinlenmesi halinde, yemin hariç, tanıklı̆ga ilişkin hükümler uygulanır." şeklindeki hükmü (m 236/1) nedeniyle mağdurun tanık olarak nitelendirilip nitelendirilemeyeceği, bunun yanı sıra yalan tanıklık suçunun faili olup ola

\footnotetext{
246 BGHSt 24, 257 (BEULKE / SWOBODA, kn. 290); BGH JR 1969, 148 (SCHMITT, vor § 48, kn. 22); BADER, vor § 48, kn. 9; GERCKE, vor § 48, kn. 8; CENTEL / ZAFER, s. 287.

247 ÖZTÜRK / TEZCAN / ERDEM / GEZER / SAYGILAR KIRIT / ALAN AKCAN / TÜTÜNCÜ / ÖZAYDIN / ALTINOK VILLEMIN / TOK, s. 303.

248 HILLENKAMP, s. 167; ROXIN / SCHUNEMANN, § 26, kn. 5; SCHMITT, vor § 48, kn. 22; GERCKE, vor § 48, kn. 8; LUDERSSEN, S. 233.

249 BADER, vor $\S 48, \mathrm{kn} .9$.

250 BGH GA 1968, 305; BGH MDR 1971, 897 (BADER, vor § 48, kn. 9).

251 CENTEL / ZAFER, s. 287.

252 LUDERSSEN, S. 232.

253 PRITTWITZ, S. 469.

254 KREY / HEINRICH, kn. 1221.

255 KREY / HEINRICH, kn. 1223.

256 BEULKE / SATZGER, kn. 291.

257 BEULKE / SATZGER, kn. 291; ALSBERG / DALLMEYER, kn. 316.
} 
mayacağı öğretide tartışılmaktadır. Türk öğretisinde hâkim görüş̧ ${ }^{258}$, mağdurun tanık olarak kabul edilemeyeceği yönündedir. Zira bu kişiler, ilgili olayda zarar gördüklerinden taraf konumundadır ve bu nedenle beyanlarının taraf beyanı olarak addedilmesi mümkün değildir. Bu bakımdan bu kişilere yemin ettirilmez ve doğruyu söyleme mecburiyetleri bulunmamaktadır. Buna karşılık öğretideki diğer görüş ${ }^{259}$, mağdurun davaya ancak katılmış olması halinde taraf haline geleceğini ve bu durumda yal an söylemiş olsa bile yalan tanıklık suçunun faili olamayacağını, buradan hareketle davaya katılmamış olan mağdurun tanıklık yapabileceğini belirtmektedir.

Bu konudaki kanaatimiz, her ne kadar kanuni düzenlemede mağdurun tanık olarak dinlenmesinden söz edilmekte ve tanıklığa ilişkin hükümlerin uygulanacağından bahsedilmekteyse de hem incelemenin tanım kısmında belirtildiği üzere tanığın kural itibariyle sanık ya da mağdur olarak yargılamada yer almayan kişi olmasından hem de bu hükmün davada katılan sıfatıyla yer alabilme yetkisine sahip olan ve böylelikle dosyayı sınırsız şekilde inceleme yetkisini haiz taraf konumundaki mağduru objektif anlamda tanık hale getirmeyeceği yönündedir. Nitekim Yargıtay kararında da açıkça suç soruşturmasında suçun mağduru olan ve yargılamanın süjesi konumunda bulunan sanığın yalan tanıklık suçunun faili olamayacağı vurgulanmıştır ${ }^{260}$. Kaldı ki katılan sıfatına sahip mağdurun, şüpheli veya sanığın CMK m 45'te yer alan yakınlarından biri olması ve bu hükme binaen ifade vermekten çekinmek istediğini belirtmesi halinde artık katılan sıfatının sona ereceği ve katılmanın hükümsüz kalacağı (CMK m 243) yönündeki görüş ${ }^{261}$ de yargilamada suçtan zarar gören olarak taraf konumundaki mağdurun tam anlamıyla tanık olarak nitelendirilemeyeceği yönündeki düşünceyi doğrulamaktadır. $\mathrm{Bu}$ nedenle mağdur, uyuşmazlığın tarafı olarak kabul edildiğinden davaya katılan olsun ya da olmasın yeminsiz şekilde dinlenir ve yalan tanıklık suçunun faili olamaz ${ }^{262}$. Bununla birliktebu durum, mağdurun duruşmadaki beyanlarının delil olarak kullanılmasın engel teşkil etmezse de ${ }^{263}$ kuşkusuz ki mağdurun ifadeleri dikkatli şekilde incelenmeli ve diğer delillerle birlikte değerlendirilmelidir ${ }^{264}$.

\section{Bilirkişi ve Uzman Kimseler}

Bilirkişi, tanıklıktan farklıdır ve esas itibariyle tanık gibi olay ve olgular üzerine algıladığı hususları aktarmaz, bu olay ve olgular üzerine tespitlerde bulunur265. Bilirkişilik, çoğu zaman yetkili muha keme merci tarafından alanında uzman herhangi bir kişinin görevlendirilmesi suretiyle gerçekleştirilir ${ }^{266}$ vebu bakımdan bu konumda bulunan kişi, tanık gibi vazgeçilemez ya da değiştirilemez bir nitelik

258 CENTEL / ZAFER, s. 288; ŞAHIN / GÖKTÜRK, s. 40; TOROSLU / FEYZIOĞLU, 207; GÖKTÜRK, s. 374; İNCE TUNÇER, s. 88.

259 ÜNVER, Yener: İftira, Suç Uydurma, Suç Üstlenme, Yalan Tanıklık ve Bilirkişilik, Suçu İhbar Etmemek Suçları, 6. Baskı, Seçkin Ya yıncılık, Ankara, 2021, s. 210; ÖZBEK / DOĞAN / BACAKSIZ, s. 588; ÜNVER / HAKERİ, s. 256. Feyzioğlu, katılanın tanık sıfatıyla dinlenemeyeceğini belirterek (FEYZIOĞLU, s. 43, 44) esasen bu görüş içerisinde telakki edilebilir. Nitekimyazar, kişinin ancak kendisinin zarar gördüğü fiille ilgili olmayan davalarda tanıklık yapabileceğine işaret etmiștir (FEYZİOĞLU, s. 45). Yine Yurtcan, katılan s1fatını haiz kişinin tanık olamayacağını açıkça belirtmekteyse de katılan olmayan mağdurun tanık olup olamayacă̆ konusunda açık bir ifadeye yer vermemektedir ki bu nedenle yazarın da bu görüşten yana olduğu sonucuna ulaşılabilir (YURTCAN, s. 213, 214). Yenisey / Nuhoğlu' nun tanıklığın tanımında "taraflardan olmayan fakat olayın tanı̆̆ı olmuş" ifadesinden (YENISEY / NUHOĞLU, s. 536) hare ketle adeta mağdurun tanık olamayacağı sonucuna ulaşılabilirse de hemen devamında mağdur ve şikâyetçi dâhil herkesin tanık olabile ceğini belirtmesi (YENISEY / NUHOĞLU, s. 537) yazarların bu görüșten yana olduklarını göstermektedir. Yine bu görüş için bkz. SOY ASLAN, s. 458. Karakehya, kanuni düzenleme nedeniyle mağdurun tanık olarak dinlenmesinin mümkün olduğunu kabul etmekte$\operatorname{dir}($ KARAKEHYA, s. 226).

260 Y. 9. CD., T., 20.02.2013, E., 2012/11127, K., 2013/2434 (INCE TUNÇER, s. 88). Benzer şekilde bkz. GÖKTÜRK, s. 374

261 MAHMUTOĞLU, Fatih Selami: “Ceza Yargılamasında Katılanın, Aynı Zamanda CMK 45. Maddede Öngörülen Kişilerden Biri Olması Halinde, Tanıklıktan Çekinme Hakkını Kullanıp Kullanamayacağı Sorunu”, Marmara Üniversitesi Hukuk Fakültesi Hukuk Araștırmalarl Dergisi, 2013, Cilt 19, Sayı 2, Prof. Dr. Nur Centel'e Armağan, s. 206, 207.

262 YENISEY / NUHOĞLU, s. 518; CENTEL / ZAFER, s. 288; ÖZEN, s. 323. Ünver, suçtan zarar görenin ve yine müdahil olmamış ise mağdurun bu suçun faili olabileceğini belirtmiştir (ÜNVER, s. 210).

263 YENISEY / NUHOĞLU, s. 518; ŞAHIN / GÖKTÜRK, s. 39.

264 ÖZTÜRK / TEZCAN / ERDEM / GEZER / SAYGILAR KIRIT / ALAN AKCAN / TÜTÜNCÜ / ÖZAYDIN / ALTINOK VILLEMIN / TOK, s. 303; CENTEL / ZAFER, s. 288.

265 ALSBERG / DALLMEYER, kn. 303; FEYZIOĞLU, s. 27.

266 HEGER / POHLREICH, kn. 366a. 
arz etmez ${ }^{267}$. Bir kimsenin tanık mı yoksa bilirkişi mi olduğu, çağrı kâğıdındaki isimlendirmeye göre değil, aslında çağrı kâğıdının içeriğine göre belirlenir ${ }^{268}$. Bununla birlikte şüphesiz ki bir bilirkişi de tanıklık yapabilir ${ }^{269}$. Bu iki şekilde olabilir: Birincisi, görevi gereği olay ve olgular üzerine belirli bir idrake varan kişinin mahkemede ifadesine başvurulmasıdır ki bunlar, uzmanlıklarının kazandırdığı bilgileri de aktardıklarından "tanık bilirkişi”" olarak nitelendirilirler ${ }^{270}$. Hatta kaza yerinde mağduru tedavi eden hekimin uzman tanık olarak çok daha doğru şekilde bilgilendirmede bulunabileceğine işaret edilmektedir ${ }^{271}$. Buna göre kaza mahal linde bulunan bir hekim, yaralının durumunu teknik bilgilerini kullanarak tanımlarsa ${ }^{272}$ ya da " $A$ 'y 01.01.2001 yllinda muayene ettim ve onun 4 aylık hamile olduğunu tespit ettim." ifadesini kullanırsa tanık bilirkişi olarak görülür ${ }^{273}$. Keza bir kimyager, incelenmek üzere kendisine getirilen maddenin uyuşturucu madde olduğunu belgelediğini mahkeme önünde beyan ederse tanık bilirkişi olarak nitelendirilir ${ }^{274}$. Bu durumda bilirkişilikten farklı olarak tanık bilirkişinin yerine başka bir bilirkişinin görevlendirilmesinden söz edilemez ${ }^{275}$. Bilirkişinin tanıklık yapabileceği ikinci hal ise bilirkişilik görevinden bağımsız olarak olayla ilgili belirli hususları idrak etmesi ve tanıklık yapmasıdır. Buna göre bilirkişilik görevi yapan bir kimse, görevinden bağımsız olarak kaza yerinde tesadüfen bulunduğu için bir olayla ilgili olarak bazı hususları idrak ederse artık tanık bilirkişi değil, yalnızca tanık olarak telakki edilir ${ }^{276}$.

Esas itibariyle Alman öğretisinde tanıklıkla bilirkişiliğin, karşılıklı olarak birbirini ortadan kaldıran kavramlar olmadığına işaret edilmektedir ${ }^{27}$. Nitekim Alman Ceza Muhakemesi Kanunu'nda bir bilirkişinin hâkimin reddini haklı gösteren sebeplerle reddedilebileceğinin belirtildiği hükmün (§ $74 \mathrm{I}$, ilk cümle) hemen devamında bilirkişinin tanık sıfatıyla dinlenmiş olmasının ret sebebi teşkil etmeye ceği (§ $74 \mathrm{I}$, ikinci cümle) ifadesine yer verilmiştir. Bu hükme benzer bir düzenleme 1412 sayılı Ceza Muhakemeleri Usulü Kanunu' nda (m 67/2) yer almaktaydı. Benzer şekilde kanun tasarısında da (m 70) tanıklığın bilirkişiliğe engel olmadığı hükmüne yer verilmiş olmasına rağmen Türkiye Barolar Birliği'nin değişiklik önerisinde "Tanıklık, bilirkişi olmaya engeldir." şeklinde tam aksi bir hükmün teklif edilmesiyle birlikte ${ }^{278}$ nihayetinde mevcut Ceza Muhakemesi Kanunu'nda tanıklar bakımından yalnızca hâkimin reddini gerektiren sebeplerin, bilirkişi hakkında da geçerli olduğu ifadesiyle (madde 69/1) yetinildiği görülmektedir. Şu hâlde Türk hukukunda mevcut düzenleme gereğince hâkimin reddinde olduğu gibi algıladığı olaylarla ilgili olarak tanıklık yapan bir kimsenin bilirkişilik yapmasından

267 HEGHMANNS, kn. 420; GEPPERT, s. 82; FEYZİOĞLU, s. 27, 28.

268 GEPPERT, s. 81, 82.

269 ROGALL, vor § 48, kn. 26; BEULKE / SWOBODA, kn. 291; SCHMITT, vor § 48, kn. 23; MAIER / PERCIC, vor § 48, kn. 30; ROGALL, vor $\S 48$, kn. 68; HEGER / POHLREICH, kn. 366a; GÖKCEN / BALCI / ALŞAHIN / ÇAKIR, s. 285.

270 FEYZİĞLU, s. 65; SOYASLAN, s. 458; YURTCAN, s. 213; ÖZBEK / DOĞAN / BACAKSIZ, s. 586. 2004 CMUK Tasarısında tanık bilirkișiye dair ayrı olarak düzenlemeye yer verilmiș olup söz konusu hükme göre özel bilgi elde edilmeksizin değerlendirilemeyen geçmiş olayları saptamak için bilirkişi sıfatıyla dinlenmeleri gerekli olanlar hakkında tanıklığa ilişkin hükümlerin uygulanacağı belirtilmiştir. Hükmün tasarıdaki gerekçesi ise şu şekildeydi: "belli bir muayeneyi veya incelemeyi yaparken değişme ve gelişmelere tanıklık yapan kiși, tanık gibidir. Bu çeșit bilirkișiye, "tanık bilirkiși”" denilir. Geçmiște gerçekleșmiş olan bir olay veya durumu, sahip olduğu özel bilgi ile açıklayıp raporunu yazan bilirkişi, bu olayın adeta tanığı olmaktadır. Bu gibi hallerde hem uzmanlık derecesindeki bilgi nedeniyle bilirkişi, hem de belli olay veya durumlara ait bilgisi nedeniyle tanığl olduğu için bilirkişiye ayrı bir statü verilmesi gerekli sayılmıştır. Talat Paşa'nın öldürülmesi ile ilgili olarak yıllar sonraki bir davada dinlenen bilirkişi bunun tipik örneğidir". Bilgi için bkz. ÖZBEK / DOĞAN / BACAKSIZ, s. 586, dn. 762

271 KÜHNE, kn. 798.

272 CENTEL / ZAFER, s. 289; ÖZTÜRK / TEZCAN / ERDEM / GEZER / SAY GILAR KIRIT / ALAN AKCAN / TÜTÜNCÜ / ÖZAY DIN / ALTINOK VILLEMIN / TOK, s. 301

273 ROXIN / SCHUNEMANN, § 26, kn. 3; BEULKE / SWOBODA, kn. 304; YURTCAN, 213; ÖZTÜRK / TEZCAN / ERDEM / GEZER / SAY GILAR KIRIT / ALAN AKCAN / TÜTÜNCÜ / ÖZAYDIN / ALTINOK VİLLEMIN / TOK, s. 301; GÖKCEN / BALCI / ALŞAHIN / ÇAKIR, s. 285; FEYZİĞLU, s. 65.

274 SOYASLAN, S. 458

275 ÖZTÜRK / TEZCAN / ERDEM / GEZER / SAYGILAR KIRIT / ALAN AKCAN / TÜTÜNCÜ / ÖZAYDIN / ALTINOK VİLLEMİN /TOK, s. 301.

276 GÖKCEN / BALCI / ALŞAHİN / ÇAKIR, s. 285.

277 GEPPERT, s. 82.

278 ÜNVER / HAKERİ, s. 257. 
söz edilemeyecek, aksi takdirde reddi bakımından talepte bulunulması gündeme gelebilecektir ${ }^{279}$. Bur rada kişinin bilirkişilik yapmasına engel teşkil eden husus, kişinin olay ve olgular üzerine algılamalara sahip olması değil, bunlar üzerine tanıklık görevini icra etmesidir ${ }^{280}$. Bu tanıklıkla birlikte artık bu kişinin bu dava konusu olayla ilgili olarak bilirkişilik yapmasından söz edilemez ${ }^{281}$.

\section{Adli Kolluk Görevlileri ve Zabıt Kâtibi}

Ceza Muhakemesi Kanunu'nda Cumhuriyet savcısının, doğrudan doğruya veya emrindeki adlî kolluk görevlileri aracılığı ile her türlü araştırmayı yapabilir; yukarıdaki maddede yazılı sonuçlara varmak için bütün kamu görevlilerinden her türlü bilgiyi isteyebileceği hükmüne yer verilmiş (CMK md 161/1), adlî kolluk görevlilerinin, el koydukları olayları, yakalanan kişiler ile uygulanan tedbirleri emrinde çalıştıkları Cumhuriyet savcısına derhâl bildirmek ve bu Cumhuriyet savcısının adliyeye ilişkin bütün emirlerini gecikmeksizin yerine getirmekle yükümlü oldukları ifade edilmiştir (CMK m 161/2). Buradan hareketle adli kolluk görevlileri de savcının yardımcısı sıfatıyla şüpheli ve sanığın lehine ve aleyhine olan delilleri toplanmasına katılacağından görev yaptıkları olayla ilgili olarak tanıkl1k yapmaları gerektiğinde savcı gibi değerlendirilmeleri gerekir. Görevlerini yerine getirirken edindikleri bilgilerle ilgili olarak kolluk görevlilerinin tanıklık yapmaları pekâlâ mümkündür ${ }^{282}$. Bununla birlikte muhakeme içerisinde, bilhassa soruşturma aşamasında belinli olay ve olgulara ilişkin algılama lara sahip olan adli kolluk görevlisinin bu olaya dair tanıklık yapması mümkün olsa da bu tanıklığın soruşturma aşamasında hukuka aykırı şekilde başvurulan delil elde etme yöntemleri karşısında söz konusu delillerin kullanılamayacak olması nedeniyle bu işlemi yapan kolluk görevlisinin tanık olarak dinlenmesi suretiyle söz konusu hukuka aykırılığın dolanılması yönündeki tehlike mutlaka dikkate alınmalıdır. Bu çerçevede söz gelimi hukuka aykırı şekilde başvurulan teknik takip işlemi nedeniyle elde edilen delilin kullanılamayacak olması karşısında hâkimin, söz konusu teknik takip işlemini yerine getiren kolluk görevlisinin tanıklığına başvurması ve ifadelerini delil olarak kullanıp hükme esas alması mümkün görülmemeli, bu ifade yasak deliller kapsamında telakki edilmelidir. Buna karşıllk kolluk görevlilerinin bilgi alma işlemi çerçevesinde edindikleri bilgilerden bahisle tanıklık yapmaları mümkündür ${ }^{283}$. Kolluk görevlilerinin tanıklık yaptıkları olayla ilgili olarak görev alıp alamayacakları konusunda savcıya ilişkin açıklamalara bakılmalı ve bu çerçevede kolluk görevlileri açısından da benzer bir değerlendirme yapılmalıdır.

Bu kapsamda son olarak zabit kâtibinin Ceza Muhakemesi Kanunu' nda hâkimle birlikte düzenlenmiş olması ve Kanun'un 32' nci maddesinde “Bu Bölümde yazılı hükümler zabıt kâtipleri hakkında da uygulanır." yer verilmiş olması karşısında bir zabıt kâtibinin tanıklık yaptığı olayla ilgili olarak görev yapması halinde reddinin gündeme gel eceği ifade edilmelidir ${ }^{284}$.

\section{SONUÇ}

Bir kişinin olay ve olgulara ilişkin algılamaları ve bunları ifade ediş şekli, kişinin tamamen kendisine özgü olduğundan tanıklık şahsi bir nitelik arz eder ve çoğu zaman tanık konumundaki kişinin bir başka kişiyle ikamesi mümkün görülmez. Bu nedendir ki tanıklık, günümüzde de halen en yaygın kullanılan ispat araçlarından biridir ve ceza muhakemesi uygulamasında oldukça önemli bir yere sa

\footnotetext{
279 ÜNVER / HAKERİ, s. 257; ÖZEN, s. 323.

280 CENTEL / ZAFER, s. 289.

281 KÜHNE, kn. 805; ÖZEN, s. 323.

282 FEYZİĞLU, s. 60. Aksi görüş için bkz. GÖKCEN / BALCI / ALŞAHİN / ÇAKIR, s. 286; ÖZEN, s. 324; ÖZTÜRK / TEZCAN / ERDEM / GEZER / SAYGILAR KIRIT / ALAN AKCAN / TÜTÜNCÜ / ÖZAYDIN / ALTINOK VİLLEMIN / TOK, s. 302.

283 FEYZİOĞLU, s. 72; ÖZEN, s. 324.

284 ÖZTÜRK / TEZCAN / ERDEM / GEZER / SAY GILAR KIRIT / ALAN AKCAN / TÜTÜNCÜ / ÖZAYDIN / ALTINOK VİLLEMİN / TOK, s. 212; SOYASLAN, s. 458; GÖKCEN / BALCI / ALŞAHIN / ÇAKIR, s. 286; YAŞAR, C. I, s. 419. Feyzioğlu, zabit kâtibi açısından tutanakları tutarken kasıtlı şekilde taraflı hareket etmesinin her zaman olmasa da ihtimal dâhilinde olduğuna dikkat çekmiştir (FEYZİOĞLU, s. 63, 64).
} 
hiptir. İncelememizde tanık konumundaki kişiyi, kural olarak kendisinin herhangi bir şekilde sanık ya da mağdur olarak yer almadı̆̆ bir yargılamada, içsel ya da dışsal olgular üzerine algılamalarını, her durumda pozitif veya negatif yöndeki ifadeleriyle ortaya koyabilecek olan ve yetkili makam tarafindan davet edildiğinde huzurda bulunup kanuni bir neden olmaksızın beyanda bulunma konusunda hukuken yükümlü olan kimse şeklinde tanımlamaya çalıştık ki çalışmamız kapsamındaki açıklamalar bu tanıma uygun biçimde gelişim göstermiştir. Bununla birlikte makalede temel olarak şu sonuçlara ulaşıldığı ifade edilebilir:

1. Dolaylı tanıklık adı verilen kulaktan duyma tanıklık mümkün olmakla birlikte şayet yetkili merciin delilin esas kaynağına ulaşma imkânı varsa, söz gelimi olay ya da olguyu ilk idrak eden kişiye erişme ihtimali söz konusu ise artık ilk kaynağa ulaşılmalı, en azından bu konuda bir çaba sarf edilmeli, dolaylı tanıklıkla yetinilmemelidir. Zira olay ve olguları ilk idrak edenle bu kişiden bunları duyan kişi arasında ne kadar fazla kişi varsa ifadenin ispat değeri de o kadar düşük olacaktır. Y etkili merci, mümkün olduğunca delilin ilk kaynağına ulaşmaya çalışmalıdır.

2. Hiç kimse ilk baştan tanıklığa elverişsiz görülemez. Kişinin kusur yeteneğine ilişkin durumu nedeniyle ceza sorumluluğunun bulunmuyor olması, tanıklık yapmasına engel teşkil eder bir husus değildir. Bu çerçevede algılama yeteneğine sahip olması ve bu algıladığı hususları anlatabilecek durumda olması kaydıyla akıl hastaları ve çocuklar da tanıklık yeteneğine sahiptir. Dolayısıyla tanıklık yapacak kişinin hem ifade verilecek konuya ilişkin genel idrak etme durumu hem de ifade konusuyla ilişkili olarak bireysel anlamda yeteneği her bir somut olay çerçevesinde yetkili makam tarafından tespit edilir ki bu nedenle tanığın huzurda bulunması beklenir, tanığa çağrı üzerine hur zurda bulunma yükümlülüğü yüklenir. Bununla birlikte yetkili merci tarafindan bir uzman yardımından faydalanılabilir. Hatta akıl hastalığı gibi bazı durumlarda uzmana başvurmadan kişinin ta nıklık yapmaya elverişli olmadığı yönünde karar verilmesi, hukuka aykırı olacaktır.

3. Hukuki görüşlerle birlikte tecrübeden kaynaklı kişisel yorumlar, şüphe, tahmin ve ön yargılardan oluşan çıkarım ve değerlendirmeler, tanıklığın konusu olamayacağından tanık konumundaki kişi, bu tür sorulara cevap vermekten kaçınabilirse de belli oranda değerlendirici ifadeler kaçınılmazdır ve bu bağlamda tanık beyanının yetkili makam tarafından dikkatli bir şekilde değerlendirilmesi gerekir. Buna göre örneğin tanıklık ifadesinde fiilin işlendiği esnada havanın aydınlık olduğu, kişinin kendini kaybetmişçesine sarhoş olduğu, şoförün aracı hızlı sürdüğü gibi olay açısından resmin ortaya çıkartılmasına etki eden çıkarımlar, tanıklığın konusu olabilir. Buna karşılık tanık konumundaki kişi, bir kimsenin kusur yeteneği üzerine bir yorumda bulunamaz, ancak kusur yeteneğinin mahkeme tarafından değerlendirilmesine yardımcı olabilecek nitelikteki olay ve olgular hakkında bilgi verebilir.

4. Bir hâkimin görev yaptığı bir dava konusu olay bakımından tanıklık yapması gerekiyorsa bu mümkün olmanın ötesinde aynı zamanda gereklidir. Ancak dava konusu olayda tanık olarak ifade veren hâkim, kanuni düzenleme gereğince aynı olayın konu olduğu yargılamada hâkimlik görevinde bulunamayacağından görevinden çekilir ve bu hâkimin yerine başka bir hâkim görevlendirilir. Şayet hâkim görevinden çekinmezse hâkimin reddi istenebilir. Bu noktada bir hâkimin tanık olarak kabul edilme ihtimali, hâkimin reddi için yeterli olmayıp bunun için muhakemenin herhangi bir aşamasında yetkili merciler tarafından olayın esasına dair hâkimin tanık sıfatıyla beyanına başvurulmuş olması gerekli ve yeterlidir. Zira aksi durumda sanık, sırf hâkim konumundaki kişinin hâkimlik sıfatının sona ermesi ya da yargılamayı sürüncemede bırakmak için hâkimin tanıklık yapması talebinde bulunabilir. Bununla birlikte bir hâkimin devam eden yargılamaya ilişkin ola rak ya da halen görülmekte olan duruşma esnasında görevinden kaynaklı olay ve olgulara ilişkin edindiği alg1 ve izlenimler üzerine duruşmada izin verildiği ölçüde kullandığı ifadeler, mesleki bilgisi olarak adlandırılır ve yargılamadan çekinmesini ya da reddedilmesini gerekli kılmaz. 
5. Tanıklık yapması gerektiğinde daha önce duruşmalara katılmış olsa bile tanıklık öncelikli oldur ğundan bir savcı da tanıklık yapabilir. Ancak savcı, aynı oturumda kesintisiz şekilde görevini ifa etmesi gerektiğinden duruşma içerisinde hem savcılık hem de tanıklık görevini üstlenemez, kendisi tanıklık yaparken mutlaka o esnada başka bir savcı, savcılık görevini üstlenmiş olmalıdır, aksi takdirde mahkeme teşekkül etmemiş olacağı için mutlak bozma nedeni gündeme gelir (CMK m 289/1-e). Ceza Muhakemesi Kanunu' nda “Duruşmada, hükme katılacak hâkimler ve Cumhuriyet savcıst ile zabıt kâtibinin ve Kanunun zorunlu müdafiliği kabul ettiği hâllerde müdafinin hazır bulunması şarttır." şeklinde bir hükme (m 188/1) yer verilmişse de düzenlemede "zorunlu müdafi" kapsama dâhil edilmiş, buna rağmen duruşmada hazır bulunma ifadesine "kesintisiz" ibaresi eklenmemiştir. Buna karş1lık hükmün, "Müdafinin mazeretsiz olarak duruşmaya gelmemesi veya duruşmay terk etmesi halinde duruşmaya devam edilebilir." şeklindeki ikinci cümlesinden hareketle söz konusu kişilerin duruşmada başka bir görev üstlenmeleri halinde duruşmaya devam edilemeyeceği sonucuna ulaşılabilir, böylelikle söz konusu ifadenin eksikliğinden kaynaklı ortaya ç1kabilecek sorunun önüne geçilebilir. Kaldı ki aynı hükmün üçüncü fikrasında "Bir oturumda bitmeyecek davada, herhangi bir nedenle bulunamayacak üyenin yerine geçmek ve oya katılmak üzere yedek üye bulundurulabilir." hükmüne de yer verilmek suretiyle bir kişinin aynı duruşmada iki görevi birden yapmasının mümkün olmadığı iyice pekiştirilmiştir. Bununla birlikte savcının kendisinin suçtan zarar görmüş olması halinde artık fiilin ispatına ilişkin beyanlarda bulunacağından ve kendi ifadelerini de esasa matuf şekilde değerlendirmesi gerekeceğinden bu olayla ilgili olarak savcılık görevinde bulunmaması gerektiği sonucuna ulaşılabilirse de hâkimde olduğu gibi savcının da tarafsızlığını şüpheye düşüren durumlarda muhakemeden çekinmesi ve savcının reddine ilişkin bir kanuni düzenleme yapılmasına yönelik bir ihtiyaç söz konusudur.

6. Müdafinin tanıklık yapması halinde ise kural, bu müdafinin görevine devam etmesi şeklinde olmalıdır. Bununla birlikte somut olayda bir zorunlu müdafilik görevi söz konusu ise bu müdafin tanık olarak ifadesinin alınması süresince söz konusu sanığa mutlaka başka bir müdafi görevlendirilmelidir. Ayrıca müdafinin tanıklık ifadesi, müvekkilinin aleyhine olduğunda avukatın müdafilik görevine devam etmesi müdafiliğin varlık sebebine aykırı olacak ve adil yargılanma hakkının ihlali sonucunu beraberinde getirebilecektir. Bu nedenle böyle bir durumda müdafi görevinden azledilmezse ya da çekinmezse mahkeme tarafindan görevinden azledilmelidir. Ayrıca müvekkilin bizzat kendisi de avukata verdiği bilgilerin açıklanmasına dair muvafakat göstermiş olabilir. Kuşkusuz ki böyle bir durumda dahi avukat, tanıklık yapmaya zorlanamaz, yine de tanıklık yapmaktan çekinebilir. Bu konuda yapılan kanuni değişikliklerle birlikte avukatlar, tanıklıktan çekinme konusunda diğer meslek sahiplerinden farklı bir yere konmuş, müvekkilin onayının tanıklık yapma yükümlülüğü değil, yalnızca tanıklık yapma hakkı tanıması yönünde bir anlayış kabul edilmiştir. Buradan hareketle müvekkilin onayına rağmen avukatın kendisi, müvekkiline ait bilgileri açıklamama yönünde bir takdirde bulunabilir. Bunun en temel nedeni, mesleğe duyulan güvenin korunması ve çok önemlisi adaletin gereği gibi tesis edilmesidir. Şüphesiz ki bu konuda Türk hur kuku, müvekkilin müdafiyi sır saklama yükümlülügünden muaf tutmuş olması halinde artık müdafinin tanıklıktan çekinme imkânı bulunmadığı Alman hukukundan çok daha ileri bir durumdadır. En baştan müdafinin tanıklık yapma konusunda her türlü konuda kendi takdirine bırakılmış, Alman öğretisindeki söz konusu tartışmalara yer bırakılmamıştır.

7. Kural olarak sanık ya da şüphelilerin birbirileri hakkında tanıklık yapmaları kabul edilmese de Ceza Muhakemesi Kanunu'ndaki soruşturma veya kovuşturma konusu suçlara iştirakten veya bu suçlar nedeniyle suçluyu kayırmaktan ya da suç delillerini yok etme, gizleme veya değiştirmekten şüpheli, sanık veya hükümlü olanların yeminsiz dinleneceklerine dair hükümden hareketle bazı hallerde suç ortaklarının tanık olarak dinlenebilmesi mümkün olabilmelidir. Her ne kadar öğretide, bu düzenleme eleştirilmekteyse de kanun koyucunun iradesinin suç otaklarının birbirleri hakkında tanıklık yapabilmelerini kabul etmek yönünde olduğu açıktır. Şu hâlde şüpheli ya da sanıkların birbirleri hakkında tanıklık yapabilmeleri durumunun sınırı belirlenmelidir. Bu noktada 
"yargılanan fiil"den hareket edilmeli, bağlantının bulunduğu bir yargılama içerisinde bir sanığın tanık sıfatıyla ifadesinin alınmasına, ancak "yargılama konusu fiile dayalı olarak yargılanmaması ve bağlantının sona ermesi” şartıyla müsaade edilmelidir. Bu noktada sırf suç ortaklarından birinin tanık olarak ifadesine başvurmak amacıyla yargılamanın ayrılması yönünde bir yönteme başvurulmamalı, kasıtlı olarak rol değişimi yapılmamalıdır. Bununla birlikte yargılama kendisine karşı tamamen sona erdirilmişse artık özel koruma değeri sona ermiş olacağından önceden sanık sıfatını haiz olmuş olsa bile bir kişi, tanık olarak dinlenebilir. 


\section{KAYNAKÇA}

ALSBERG, Max / DALLMEYER, Jens: Der Beweisantrag im Strafprozess, 7. Auflage, Carl Heymanns Verlag, Köln, 2019.

ARNTZEN, Friedrich: “Untere Altersgrenze der Zeugeneignung”, Deutsche Richterzeitung (DRiZ), 1976, s. 20.

AYDIN, Devrim: Ceza Muhakemesinde Deliller, Yetkin Yayınları, Ankara, 2014.

BADER, Markus: Karlsruher Kommentar zur Strafprozessordnung mit GVG, EGGVG und EMRK, 8. Auflage, C.H.Beck, München, 2019.

BECKER, Jögr-Peter: in Löwe-Rosenberg Die Strafprozeßordnung und das Gerichtsverfassungsgesetz Großkommentar, Band 6, 27. Auflage, DeGruyter, Berlin/Boston, 2020.

BEULKE, Werner / SWOBODA, Sabine: Strafprozessrecht, 15. Auflage, C.F.Müller, Heidelberg, 2020.

CENTEL, Nur / ZAFER, Hamide: Ceza Muhakemesi Hukuku, 19. Baskı, Beta Yayıncılık, İstanbul, 2020.

CENTEL, Nur: Ceza Muhakemesi Hukukunda Hâkimin Tarafsızlı̆̆l, Kazancı Yayınları, İstanbul, 1996.

DALLINGER, Wilhelm: "Aus der Rechtsprechung des Bundesgerichtshofes in Strafsachen", Monatsschrift für Deutsches Recht (MDR), 1957, s. 13-17.

DOSE, Norbert: "Der Sitzungsvertreter und der Wirtschaftsreferent der Staatsanwal tschaft als Zeuge in der Hauptverhandlung", Neue Juristische Wochenschrift (NJW), 1978, s. 349-354.

DUNNEBIER, Hanns: “Die Verbindung von Strafsachen nach $\S \S 2$ bis 4, 13StPO”, Juristische Rundschau (JR), 1975, s. 1-5.

DURSUN, Selman: Disiplinlerarası Bir Yaklaşımla Ceza Hukukunda Hareket Kavram ve Terimi, Seçkin Yayınc1lik, Ankara, 2021.

EISENBERG, Ulrich: Beweis der StPO, Spezialkommentar, 10. Auflage, C.H.Beck, Müchen, 2017.

FEYZİĞLU, Metin: Ceza Muhakemesi Hukukunda Tanıklı, US-A Yayıncılık, Ankara, 1996.

GEPPERT, Klaus: “Der Zeugenbeweis”, Juristische Ausbildung (Jura), 2001, s. 80-88.

GERCKE, Björn: Strafprozessordnung, Heidelberger Kommentar, 6. Auflage, C.F.Müller, Heidelberg, 2019.

GLEY, Chrisra: "Psychologische Grundlagen und Kriterien der Beurteilung von Zeugenaussagen bei Kindern und J ugendlichen", Der Strafverteidiger (StV), 1987, s. 403-410.

GÖKCEN, Ahmet / BALCI, Murat / ALŞAHIN, M. Emin / ÇAKIR, Kerim: Ceza Muhakemesi Hukuku, 5. Bask1, Adalet Yayınevi, Ankara, 2020.

GÖKTÜRK, Neslihan: "Yalan Tanıklık Suçu (TCK m. 272)", Gazi Üniversitesi Hukuk Fakültesi Dergisi, 2016, Cilt 20, Sayı 1, s. 347-409.

HANACK, Ernst-Walter: “Die Rechtsprechung des Bundesgerichtshofs zum Strafverfahrensrecht", Juristenzeitung (JZ), 1971, s. 89-92.

HARTMANN, Arthur / SCHMITT, Rolf: Strafprozessrecht, 7. Auflage, Rolf Schmidt Verlag, Hamburg, 2018.

HEGER, Martin/ POHLREICH, Erol: Strafprozessrecht, 2. Auflage, Verlag W. Kohl hammer, Stuttgart, 2018.

HEGHMANNS, Michael: Strafverfahren, Springer, Heidelberg, 2014.

HILLENKAMP, Thomas: "Der praktische Fall - Strafrecht: Das Aufnahmeritual und seine Folgen”, Juristische Schulung (JuS), 2001, s. 159-167.

HOLTZ, Günter: "Aus der Rechtsprechung des Bundesgerichtshofs in Strafsachen", Monatsschrift für Deutsches Recht (MDR), 1977, s. 105-109.

IGNOR, Alexander / Bertheau, Camilla: Löwe-Rosenberg Die Strafprozeßordnung und das Gerichtsverfassungsgesetz, Band 2, 27. Auflage, DeGruyter, Berlin, 2018. 
İNCE TUNÇER, Asuman: Yalan Tanıklık Suçu, Seçkin Yayıncılık, Ankara, 2020.

JOECKS, Wolfgang: Strafprozessordnung Studienkommentar, 4. Auflage, C.H.Beck, München, 2015.

KARAKEHY A, Hakan: Ceza Muhakemesi Hukuku, 2. Baskı, Savaş Yayınevi, Ankara, 2016.

KINDHÄUSER, Urs / SCHUMANN, Kay H.: Strafprozessrecht, 5. Auflage, Nomos, Baden-Baden, 2019.

KOCA, Mahmut: “Ceza Muhakemesi Hukukunda Deliller”, Ceza Hukuku Dergisi, 2006, Say1 1, s. 207-225.

KREY, Volker / HEINRICH, Manfred: Deutsches Strafverfahrensrecht, 2. Auflage, Verlag W. Kohlhammer, Stuttgart, 2019.

KUDLICH, Hans / ROY, René: “Die Zeugnisverweigerungsrechte der StPO”, Juristische Arbeitsblätter (JA), 2003, s. 565-573.

KUNTER, Nurullah: Ceza Muhakemesi Hukuku, Beta Yayıncıllk, İstanbul, 1989.

KÜHNE, Hans-Heiner: Strafprozessrecht, 9. Auflage, C.F.Müller, Heidel berg, 2015.

LUDERSSEN, Klaus: "Rollenkonflikte im Verfahren: Zeuge oder Beschul digte", wistra-Zeitschrift für Wirtschaft, Steuer, Strafrecht (wistra), 1983, s. 231-233.

MAHMUTOĞLU, Fatih Selami / DURSUN, Selman: Türk Hukukunda Müdafiin Yasaklllık Halleri, Seçkin Yayıncilık, Ankara, 2004.

MAHMUTOĞLU, Fatih Selami: "Ceza Yargılamasında Katılanın, Aynı Zamanda CMK 45. Maddede Öngörülen Kişilerden Biri Olması Halinde, Tanıklıktan Çekinme Hakkını Kullanıp Kullanamayacağı Sorunu", Marmara Üniversitesi Hukuk Fakültesi Hukuk Araşttrmaları Dergisi, 2013, Cilt 19, Sayı 2, Prof. Dr. Nur Centel'e Armağan, s. 191-210.

MAIER, Stefan / PERCIC, Marcus: Münchener Kommentar Strafprozessordnung, 1. Auflage, C.H.Beck, München, 2014.

MICHEL, Norbert: “Der Richter als Zeuge im Strafverfahren”, Monatsschrift für Deutsches Recht (MDR), 1992, S. 1026.

MIEBACH, Klaus: "Die freie Beweiswürdigung der Zeugenaussage in der neueren Rechtsprechung des BGH", Neue Zeitschrift für Strafrecht-Report (NStZ-RR), 2014, s. 233-238.

MOSBACHER, Andreas: “Aktuelles Strafprozessrecht”, Juristische Schulung (JuS), 2019, s. 129-133.

NESTLER, Nina: “'Wer einmal lügt, demglaubt man nicht..' - Fal schaussage, Glaubhaftigkeit, Lügendetektor", Juristische Arbeitsblätter (JA), 2017, s. 10-16.

OSTENDORF, Heribert/ BRUNING, J anuque: Strafprozessrecht, 4. Auflage, Nomos, Baden-Baden, 2021.

OTTE, Lars: in Henning Radtke/Olaf Hohmann Strafprozessordnung Kommentar (HH), Verlag Franz Vahlen, München, 2011.

ÖZBEK, Veli Özer / DOĞAN, Koray / BACAKSIZ, Pınar: Ceza Muhakemesi Hukuku, 14. Baskı, Seçkin Ya yınc1lik, Ankara, 2021.

ÖZEN, Mustafa: Ceza Muhakemesi Hukuku Dersleri, 4. Baskı, Adalet Yayınevi, Ankara, 2019.

ÖZTÜRK, Bahri / TEZCAN, Durmuş / ERDEM, Mustafa Ruhan / GEZER, Özge Sirma / SAYGILAR KIRIT, Yasemin F. / ALAN AKCAN, Esra / TÜTÜNCÜ, Efser Erden / ÖZAYDIN, Özlem / ALTINOK VILLEEMiN, Derya / TOK, Mehmet Can: Nazari ve Uygulamalı Ceza Muhakemesi Hukuku, 15. Baskı, Seçkin Ya yincillk, Ankara, 2021.

PFEIFFER, Gerd: Strafprozessordnung Kommentar, 5. Auflage, Verlag C.H.Beck, München, 2005.

PRITTWITZ, Cornelius: “Der Mitbeschuldigte - ein unverzichtbarer Belastungszeuge?", Neue Zeitschrift für Strafrecht (NStZ), 1981, s. 463-469.

RENGIER, Rudolf: “Anmerkung: BGH, Urt. v. 4.11.1986 - 1 StR 498/86”, Der Strafverteidiger (StV), 1988, s. 465-468. 
ROGALL, Klaus: Systematischer Kommentar zur Strafprozessordnung mit GVG und EMRK, Band I, 5. Auflage, Carl Heymanns Verlag, Köln, 2018.

ROXIN, Claus / SCHUNEMANN, Bernd: Strafverfahrensrecht, 29. Auflage, C.H.Beck, München, 2017.

SCHMITT, Bertram in Beckische Kurz Kommentar, Meyer-Goßner/Schmitt Strafprozessordnung mit GVG und Nebengesetzen, 64. Auflage, C.H.Beck, München, 2021.

SCHNEIDER, Hartmut: in Karlsruher Kommentar Strafprozessordnung, 8. Auflage, C.H.Beck, München, 2019.

SEEBODE, Manfred / SY DOW, Frit: “'Hörensagen ist hal b gelogen' Das Zeugnis vom Hörensagen im Strafprozeß", Juristenzeitung (JZ), 1980, s. 506-516.

SENGE, Lothar: Karlsruher Kommentar zur Strafprozessordnung mit GVG, EGGVG und EMRK, 8. Auflage, C.H.Beck, München, 2019.

SOYASLAN, Doğan: Ceza Muhakemesi Hukuku, 8. Baskı, Yetkin Yayınları, Ankara, 2020.

ŞAHIN, Cumhur / GÖKTÜRK, Neslihan: Ceza Muhakemesi Hukuku, Cilt II, 11. Baskı, Seçkin Yayıncılık, Ankara, 2021.

TAŞKIN, Ozan Ercan: Kışkırtıcı Ajan, Seçkin Yayıncılık, Ankara, 2011.

TOROSLU, Nevzat / FEYZİOĞLU, Metin: Ceza Muhakemesi Hukuku, 20. Baskı, Savaş Yayınevi, Ankara, 2020.

ÜNVER, Yener / HAKERİ, Hakan: Ceza Muhakemesi Hukuku, 16. Baskı, Adalet Yayınevi, Ankara, 2019.

ÜNVER, Y ener: İftira, Suç Uydurma, Suç Üstlenme, Yalan Tanıklık ve Bilirkişilik, Suçu İhbar Etmemek Suçları, 6. Baskı, Seçkin Yayıncılık, Ankara, 2021.

VOLK, Klaus / ENGLÄNDER, Armin: Grundkurs StPO, 10. Auflage, C.H.Beck, München, 2021.

von SCHLIEFFEN, J asper Graf: in AnwaltKommentar StPO Strafprozessordnung, 2. Auflage, Deutscher Anwalt Verlag, Bochum, 2010.

WIDMAIER, Gunter: “Anforderungen an Beweisantrag", Neue Zeitschrift für Strafrecht (NStZ), 1993, s. 602604.

YAŞAR, Osman: Yeni İ̧̧tihatlarla Uygulamalı ve Yorumlu Ceza Muhakemesi Kanunu, Cilt 1, 9. Baskı, Seçkin Yayıncilık, Ankara, 2020.

YENISEY, Feridun / NUHOĞLU, Ayşe: Ceza Muhakemesi Hukuku, 8. Baskı, Seçkin Yayıncılık, Ankara, 2020.

YURTCAN, Erdener: Ceza Muhakemesi Kanunu Şerhi, 9. Baskı, Seçkin Yayıncılık, Ankara, 2019. 